\title{
Fundamentals and Applications of Chitosan
}

\author{
Nadia Morin-Crini, Eric Lichtfouse, Giangiacomo Torri, and Grégorio Crini
}

\begin{abstract}
Chitosan is a biopolymer obtained from chitin, one of the most abundant and renewable material on Earth. Chitin is a primary component of cell walls in fungi, the exoskeletons of arthropods, such as crustaceans, e.g. crabs, lobsters and shrimps, and insects, the radulae of molluscs, cephalopod beaks, and the scales of fish and lissamphibians. The discovery of chitin in 1811 is attributed to Henri Braconnot while the history of chitosan dates back to 1859 with the work of Charles Rouget. The name of chitosan was, however, introduced in 1894 by Felix HoppeSeyler. Because of its particular macromolecular structure, biocompatibility, biodegradability and other intrinsic functional properties, chitosan has attracted major scientific and industrial interests from the late 1970s. Chitosan and its derivatives have practical applications in food industry, agriculture, pharmacy, medicine, cosmetology, textile and paper industries, and chemistry. In the last two decades, chitosan has also received much attention in numerous other fields such as dentistry, ophthalmology, biomedicine and bio-imaging, hygiene and personal care, veterinary medicine, packaging industry, agrochemistry, aquaculture, functional textiles and cosmetotextiles, catalysis, chromatography, beverage industry, photography, wastewater treatment and sludge dewatering, and biotechnology. Nutraceuticals and cosmeceuticals are actually growing markets, and therapeutic and biomedical products should be the next markets in the development of chitosan. Chitosan is also the
\end{abstract}

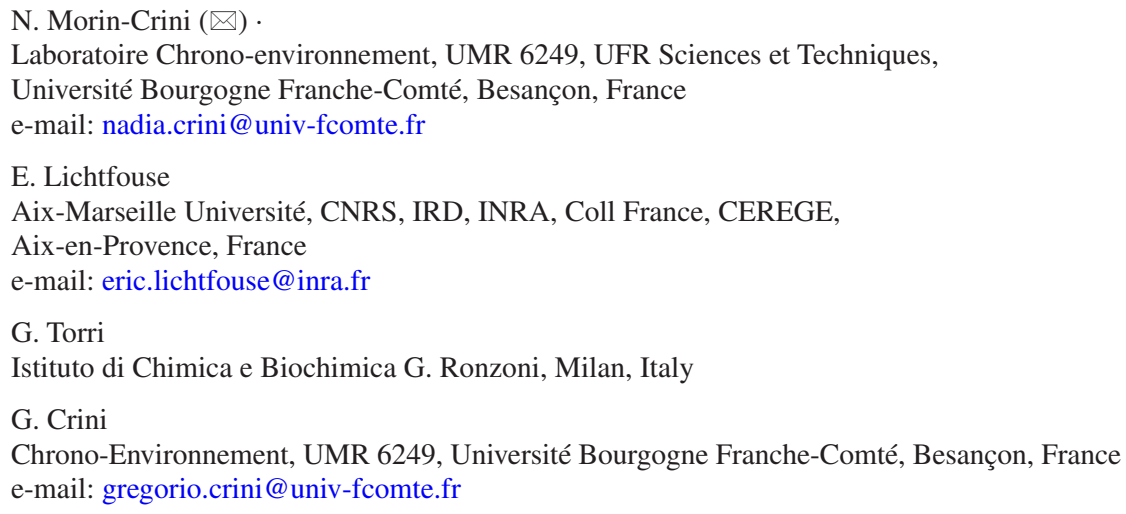


object of numerous fundamental studies. An indication of the widespread exploitation and constantly growing importance of this biopolymer is the total of over 58,625 scientific articles published between 2000 and 2017. In this chapter, after a description of chitosan fundamentals, we highlight selected works on chitosan applications published over the last two decades.

Keywords Chitosan · Chitin · Biopolymer · Fundamentals · Properties ·

Applications

\subsection{Introduction}

Main commercial polymers are derived from petroleum-based raw products using processing chemistry that is not always safe or environmental friendly. Over the past three decades, there has been a growing interest in developing natural alternatives to synthetic polymers, namely biopolymers. Biopolymers are polymers derived from living organisms or synthetized from renewable resources. They have expanded significantly due to their biological origin and mostly to their non-toxicity and biodegradable nature. Biopolymers include polysaccharides such as cellulose, starch, chitin/chitosan, and alginates.

Because of its remarkable macromolecular structure, physical and chemical properties, bioactivities, and versatility, quite different from those of synthetic polymers, the biopolymer chitosan has received much attention in fundamental science, applied research and industrial biotechnology (Crini et al. 2009; Kim 2011, 2014; Miranda Castro and Lizárraga Paulín 2012; Teng 2012; Sashiwa and Harding 2015; Dima et al. 2017; Philibert et al. 2017). Chitosan and its derivatives have practical applications in numerous fields: food industry and nutrition, agriculture and agrochemistry, aquaculture, pharmacy, medicine and biomedicine, dentistry, ophthalmology, cosmetology, hygiene and personal care, bio-imaging, veterinary medicine, textile and fiber industries, paper industry, chemistry, catalysis, chromatography, beverage industry, photography, wastewater treatment and sludge dewatering, biotechnology, and nanotechnology (Davis 2011; Ferguson and O'Neill 2011; Sarmento and das Neves 2012; Yao et al. 2012; Bautista-Baños et al. 2016; Dutta 2016; Ahmed and Ikram 2017; Amber Jennings and Bumgardner 2017a, b; Han et al. 2018; Pakdel and Peighambardoust 2018; Pellá et al. 2018; Sharif et al. 2018; Song et al. 2018; Wei et al. 2018; Zhao et al. 2018).

Chitosan is a semi-synthetic commercial aminopolysaccharide derived by deacetylation of the naturally occurring biopolymer chitin. Chitin is the most abundant of the renewable polysaccharides in the marine environment and one of the most abundant on Earth after cellulose (Muzzarelli 1977; Roberts 1992a; Kurita 2006; Rinaudo 2006; Souza et al. 2011). Chitin is an important source of carbon and nitrogen for marine organisms and its ecological importance in the marine environment is nowadays recognized. The main sources exploited for chitin and chitosan 
production at industrial scale are marine crustaceans, the shells of shrimps and crabs and the bone plate of squids (Kean and Thanou 2011; Nwe et al. 2011a, b; Kim 2014; Younes and Rinaudo 2015; Elieh-Ali-Komi and Hamblin 2016; Dima et al. 2017; Philibert et al. 2017; El Knidri et al. 2018).

Chitosan extraction from crustaceans in food industry wastes is economically feasible (Truong et al. 2007; Crini et al. 2009). In addition, its commercial production allows the recovery of pigments, proteins, fish meal additive in aquaculture, and also nutraceuticals which are beneficial in human health promotion (Philibert et al. 2017; Dave and Routray 2018). Chitosan can be marketed as a green product. Chitosan is also of great commercial interest due to its high percentage of nitrogen, of $6-7 \%$, compared to synthetically substituted cellulose, of $1.25 \%$, that makes it an effective chelating and complexing agent. Other reasons are undoubtedly its appealing polyelectrolyte properties at acidic $\mathrm{pH}$, and biological properties. Indeed, most of the applications can be related to its cationic nature, which is unique among abundant polysaccharides and natural polymers. Chitosan has unique characteristics such as biocompatibility and biodegradability, and possess reactive functional groups that make is useful in different areas of applications in the form of solutions, suspensions, gels/hydrogels, powders, microparticles/nanoparticles, beads, sponges, foams, membranes and films, or fibers/nanofibers (Muzzarelli 1977; Roberts 1992a; Crini 2005; Kurita 2006; Rinaudo 2006; Crini et al. 2009; Younes and Rinaudo 2015).

The literature on chitosan is vast and spread across different disciplines including chemistry, biochemistry, health science, agriculture and ecology. The past two decades have shown a fast increase in the number of studies on chitosan. Between 2000 and 2017, 58,625 chitosan-related publications have been published including 18,097 on applications (ISI Web of Science database). It is interesting to note that a majority of these works come from Asian nations including Japan (the undisputed leader), Korea, China, Singapore, Taiwan and Thailand (Khor and Lim 2003). A large number of generalist reviews and book chapters has been also published on practically all the aspects of chitosan biopolymer, so many that it would not be feasible to cite them all. Table 2.1 lists selected comprehensive reviews and book chapters on the history, production, characterization, structure, chemistry, derivatives, and toxicology of chitosan. Table 2.2 shows the top ten most cited reviews in the ISI Web of Science database for 2000-2017 with "Chitosan" and "Review" in the topic.

This chapter summarizes some of the developments related to the applications of this biopolymer, based on a substantial number of relevant references, and provides useful information about its most important features. After a brief description of chitosan fundamentals, we present an overview of the applications of chitosan. We include an extensive bibliography of recent studies on chitosan, both basic and applied. Nevertheless, the examples presented are not exhaustive due to the very large number of papers published. 
Table 2.1 Selected reviews published during the last two decades on the history, production, characterization, structure, chemistry, derivatives and toxicology of chitosan

\begin{tabular}{|c|c|}
\hline General topic & References \\
\hline $\begin{array}{l}\text { Characterization } \\
\text { Degree of deacetylation } \\
\text { Molecular weight } \\
\text { Distribution of N-acetyl } \\
\text { groups } \\
\text { Spectroscopy: IR, NMR, } \\
\text { Raman, X-Ray } \\
\text { Elemental analysis } \\
\text { Acid-base titration } \\
\text { Conductometric/ } \\
\text { Potentiometric titration } \\
\text { Colloid titration } \\
\text { Chemical/Enzymatic } \\
\text { hydrolysis }\end{array}$ & $\begin{array}{l}\text { Heux et al. (2000), No and Meyers (2000), Jiang et al. } \\
\text { (2003), Shahidi and Abuzaytoun (2005), Wang et al. (2006), } \\
\text { Kasaai (2008, 2009, 2011), Crini et al. (2009), Dos Santos } \\
\text { et al. (2009), Maniukiewicz (2011), de Alvarenga (2011), } \\
\text { Czechowska-Biskup et al. (2012), Zając et al. (2015), } \\
\text { Sivashankari and Prabaharan (2017), and Tsai and Chen } \\
\text { (2017) }\end{array}$ \\
\hline $\begin{array}{l}\text { Chemistry } \\
\text { Solubility } \\
\text { Solution state/Gel state } \\
\text { Chain conformation } \\
\text { Polyelectrolyte complexes, } \\
\text { macromolecular complexes, } \\
\text { electrostatic properties } \\
\text { Aggregation } \\
\text { Self-assembly/Self-assembled } \\
\text { systems }\end{array}$ & $\begin{array}{l}\text { Hudson and Smith (1998), Ravi Kumar (2000), Hejazi and } \\
\text { Amiji (2001), Kubota and Shimoda (2004), Bodnar et al. } \\
\text { (2005), Muzzarelli and Muzzarelli (2005), Shahidi and } \\
\text { Abuzaytoun (2005), Crini et al. (2009), Pillai et al. (2009), } \\
\text { Hamman (2010), Uragami and Tokura (2010), Jayakumar } \\
\text { et al. (2010a), Lakshmanan et al. (2011), Ujang et al. (2011), } \\
\text { Rinaudo (2012), Teng (2012), Zambito (2013), Kim and } \\
\text { Venkatesan (2014), Mateescu et al. (2015a, b), Younes and } \\
\text { Rinaudo (2015), Lizardi-Mendoza et al. (2016), and Salehi } \\
\text { et al. (2016) }\end{array}$ \\
\hline $\begin{array}{l}\text { Derivatives } \\
\text { Physical modifications } \\
\text { Chemical modifications: } \\
\text { derivatization, cross-linking, } \\
\text { grafting reactions, hydrolysis } \\
\text { Gels/Hydrogels } \\
\text { Glucosamines/ } \\
\text { Oligosaccharides } \\
\text { Chitooligosaccharides/ } \\
\text { Chitosan oligomers/ } \\
\text { Chitooligomers } \\
\text { Technology/Nanotechnology/ } \\
\text { Electrospinning } \\
\text { Films/Membranes } \\
\text { Fibers/Nanofibers }\end{array}$ & $\begin{array}{l}\text { Synowiecki and Al-Khateeb (2003), Canh et al. (2004), Jalal } \\
\text { Zohuriaan-Mehr (2005), Wang et al. (2006), Kurita (1986, } \\
\text { 1998, 2006), Crini et al. (2009), Muzzarelli and Muzzarelli } \\
\text { (2009), Dutta and Dutta (2011), Kim (2011, 2014), Kim and } \\
\text { Je (2011), Kim and Kim (2011), Vidanarachchi et al. (2011), } \\
\text { Xiao et al. (2012), Yao et al. (2012), Ahmadi et al. (2015), } \\
\text { Ahmed and Ikram (2017), Aminabhavi and Dharupaneedi } \\
\text { (2017), Ruiz and Corrales (2017), Argüelles-Monal et al. } \\
\text { (2018), Divya and Jisha (2018), Liang et al. (2018), and } \\
\text { Liaqat and Eltem (2018) }\end{array}$ \\
\hline History & $\begin{array}{l}\text { Jeuniaux (1966), Muzzarelli (1977), Roberts (1992a), } \\
\text { Winterowd and Sandford (1995), Labrude (1997), Labrude } \\
\text { and Becq (2003), Shahidi and Abuzaytoun (2005), Rauh and } \\
\text { Dornish (2006), Wisniak (2007), Crini et al. (2009), } \\
\text { Khoushab and Yamabhai (2010), Nwe et al. (2011b), } \\
\text { Muzzarelli et al. (2012), Berezina (2016), Annu et al. (2017), } \\
\text { and Karthik et al. (2017) }\end{array}$ \\
\hline
\end{tabular}


Table 2.1 (continued)

\begin{tabular}{|c|c|}
\hline General topic & References \\
\hline $\begin{array}{l}\text { Production } \\
\text { Sources } \\
\text { Industrial production } \\
\text { Extraction: chemical, } \\
\text { biological, enzymatic } \\
\text { Microorganisms } \\
\text { Chitin deacetylases }\end{array}$ & $\begin{array}{l}\text { Viney and Harish (2002), Synowiecki and Al-Khateeb } \\
\text { (2003), Sen (2005), Kurita (2006), Abdou et al. (2008), } \\
\text { Peniche et al. (2008), Crini et al. (2009), Brück et al. (2011), } \\
\text { Davis (2011), Jo et al. (2011), Knezevic-Jugovic et al. } \\
\text { (2011), Nwe et al. (2011a, b, 2013, 2014), Arbia et al. } \\
\text { (2013), Gortari and Hours (2013), Setyahadi (2013), Kaur } \\
\text { and Dhillon (2014, 2015), Aljawish et al. (2015), Younes and } \\
\text { Rinaudo (2015), Majekodunmi (2016), Sivashankari and } \\
\text { Prabaharan (2017), Dave and Routray (2018), de Lima } \\
\text { Batista et al. (2018), El Knidri et al. (2018), and Grifoll- } \\
\text { Romero et al. (2018) }\end{array}$ \\
\hline $\begin{array}{l}\text { Structure } \\
\text { Structural aspects/ } \\
\text { Morphology/Crystallinity } \\
\text { Crystallography } \\
\text { Structure-property relationship }\end{array}$ & $\begin{array}{l}\text { Vårum and Smidsrød (2004a), Dutta et al. (2004), Kurita } \\
\text { (2006), Rinaudo (2006), Dash et al. (2011), Younes and } \\
\text { Rinaudo (2015), and Sahariah and Másson (2017) }\end{array}$ \\
\hline $\begin{array}{l}\text { Toxicology } \\
\text { Toxicity } \\
\text { Cytotoxicity } \\
\text { Biodegradation }\end{array}$ & $\begin{array}{l}\text { Kurita (1998), Pillai et al. (2009), Kean and Thanou (2010), } \\
\text { Dash et al. (2011), Jimtaisong and Saewan (2014), Sahariah } \\
\text { and Másson (2017), and Sadler and Funnell (2018) }\end{array}$ \\
\hline
\end{tabular}

Table 2.2 The top ten most cited reviews in the ISI Web of Science database for 2000-2017 with "Chitosan" AND "Review" in the topic; out of a total of 2702 reviews appearing, October 01, 2018

1. Rinaudo M (2006) Chitin and chitosan: Properties and applications. Progress in Polymer Science 31:603-632. Times cited: 3092.

2. Kumar MNVR (2000) A review of chitin and chitosan applications. Reactive and Functional Polymers 46:1-27. Times cited: 2297.

3. Crini G (2006) Non-conventional low-cost adsorbents for dye removal. Bioresource Technology 97:1061-1085. Times cited: 2229.

4. Rabea EI, Badawy MET, Stevens CV, Smagghe G, Steurbaut W (2003) Chitosan as antimicrobial agent: Applications and mode of action. Biomacromolecules 4:1457-1465. Times cited: 1401.

5. Agnihotri SA, Malikarjuna NN, Aminabhavi TM (2004) Recent advances on chitosan-based micro- and nanoparticles in drug delivery. Journal of Controlled Release 100:5-28. Times cited: 1388.

6. Suh JKF, Matthew HWT (2000) Application of chitosan-based polysaccharide biomaterials in cartilage tissue engineering: A review. Biomaterials 21:2589-2598. Times cited: 1221.

7. Berger J, Reist M, Mayer JM, Felt O, Peppas NA, Gurny R (2004) Structure and interactions in covalently and ionically crosslinked chitosan hydrogels for biomedical applications. European Journal of Pharmaceutics and Biopharmaceutics. 57:19-34. Times cited: 1120.

8. Dash M, Chiellini F, Ottenbrite RM, Chiellini E (2011) Chitosan - A versatile semi-synthetic polymer in biomedical applications. Progress in Polymer Science 36:981-1014. Times cited: 1110.

9. Shahidi F, Arachchi JKV, Jeon YJ (1999) Food applications of chitin and chitosans. Trends in Food Science Technology. 10:37-51. Times cited: 1066.

10. Khor E, Lim LY (2003) Implantable applications of chitin and chitosan. Biomaterials 24:2339-2349. Times cited: 1053. 


\subsection{Chitosan Production and Properties}

\subsubsection{History}

In 1811, Braconnot, Director of the Jardin Botanique of Nancy, France, discovered an alkaline-insoluble fraction from mushrooms by treatment with dilute warm alkali (Simonin 1856, 1870, 2013; Prévost and D’Amat 1956; Tracey 1957; Jeuniaux 1966; Muzzarelli 1977; Roberts 1992a; Winterowd and Sandford 1995; Labrude 1997; Labrude and Becq 2003; Wisniak 2007). Braconnot described this new product containing a substantial percent of nitrogen and found that the liquid contained acetate of ammonia contaminated with oil (Braconnot 1811, 1813). This fraction also produced acetic acid by degradation with concentrated sulfuric acid (Braconnot 1811; Tracey 1957; Rudall and Kenchington 1973). Braconnot gave the name alkaline-insoluble fraction as fongine/fungine, a substance "d'une nature particulière".

In 1823, Odier isolated a similar alkaline-insoluble fraction from the elytra of insects by repeated treatments with hot hydroxide solutions (Odier 1823). He gave it the name of chitine/chitin, from Greek word chitos, meaning tunic or envelope (Odier 1823; Rudall and Kenchington 1973; Souza et al. 2011). However, Odier tested for nitrogen in this residue and found none. Odier's paper was promptly published in an English translation by Children in 1824 (Children 1824). Children, repeating the same experiments, also extracted an alkaline-insoluble fraction from may bug elytra and found the presence of nitrogen by elemental analysis (Children 1824; Tracey 1957; Nwe et al. 2011b).

In 1843, Lassaigne isolated a chitinous material from treatment of exoskeleton of silkworm butterfly and confirmed the presence of nitrogen in chitin (Lassaigne 1843). He proved that chitin was not a cellulose but a new product containing nitrogen (Tracey 1957). The same year, the Lassaigne's finding were corroborated by Payen (1843), although initially he had convinced himself in 1840 that Braconnot's fungine was cellulose (Tracey 1957).

In the 1870s, Ledderhose hydrolyzed arthropod chitin with the aim to identify the structure of the products (Ledderhose 1876, 1878). In 1875, Ledderhose, treating lobster shells with hot concentrated hydrochloric, found that the shells dissolved in this solution and that on evaporation the solution yielded characteristic crystals. He identified the crystalline compound as a new amino-containing sugar, which he named glykosamin/glucosamine (Ledderhose 1876). Later, Ledderhose showed that acetic acid was also a product of hydrolysis of arthropod chitin (Ledderhose 1878). The presence of glucosamine as the repeated unit of chitin was confirmed a few years later by the works of Winterstein (Winterstein 1893, 1894) and Gilson (Gilson 1894, 1895). At the ends of the 1890s, it was established that chitin occurs in both animals and plants and that there was no detectable chemical differences between products from the two sources. However, the controversy of the structure of chitin has continued. 
The history of chitosan dates back to 1859 with the work of Rouget (Rouget 1859; Brimacombe and Webber 1964; Muzzarelli 1977; Sharon 1980; Roberts 1992a; Winterowd and Sandford 1995). Rouget treated chitin with strong alkali, which resulted in a new substance that could, unlike chitin itself, be dissolved in acidic aqueous solutions (Rouget 1859). He named the product "chitine modifiée", modified chitin. In 1894, Hoppe-Seyler treated the shells of crabs, scorpions and spiders with potassium hydroxide at $180{ }^{\circ} \mathrm{C}$ and found a "new" product (HoppeSeyler 1894). He gave it the name of chitosan. This product was a partially deacetylated, acid-soluble derivative of chitin. This was also prepared from fungal material by both Winterstein (1894) and Gilson (1894).

In the middle of the 1930s, the structure of chitin and chitosan was characterized using data from X-ray diffraction (Meyer and Pankow 1935; Clark and Smith 1936) and later by enzymatic analysis and infrared spectroscopy (Muzzarelli 1977; Roberts 1992a). In 1936, there was the first use in papermaking industry. In the same year, two patents, one for producing chitosan from chitin and the other for making films and fibers from chitosan, were obtained by Rigby. However, lack of adequate manufacturing facilities and mostly cutthroat competition from synthetic polymers restricted their commercial development. "Re-discovery" and revived interest in the 1970s encouraged the need to better utilize biowastes from marine crustaceans (Muzzarelli 1977; Roberts 1992a, 1998; Winterowd and Sandford 1995; Rauh and Dornish 2006; Wisniak 2007; Crini et al. 2009; Khoushab and Yamabhai 2010; Nwe et al. 2011b). Several manufacturers started to produce and to market chitin and chitosan products. Numerous patents have been filed since the 1970s, and an abundant scientific literature has built up (Muzzarelli et al. 2012; Berezina 2016; Annu et al. 2017; Karthik et al. 2017). Today, there are more than 2000 applications of chitin, chitosan and their numerous derivatives (Philibert et al. 2017).

\subsubsection{Chitin}

Among numerous biopolymers, chitin is produced in the largest amounts, and after cellulose, it is the most abundant organic compound from living organisms on Earth. This polysaccharide is widely distributed in the animal and vegetal kingdom, constituting an important renewable resource. Chitin is found in the exoskeleton of crustaceans, the cuticles of insects, and the cell walls of fungi (Rudall and Kenchington 1973; Muzzarelli 1977; Muzzarelli et al. 1986a; Roberts 1992a; Kurita 1986, 1998, 2006; Rinaudo 2006; Nwe et al. 2011b). Other examples are given in Table 2.3. The content of chitin is 30-40\% in shrimps, 15-30\% in crabs, $20-30 \%$ in krills, $20-40 \%$ in squids, 3-6\% in clams, 3-6\% in oysters, 5-25\% in insects and 10-25\% in fungi (Muzzarelli et al. 1986a; Skjåk-Braek et al. 1989; Roberts 1992a; Horst et al. 1993; Felt et al. 1998; Kurita 2006; Rinaudo 2006; Nwe et al. 2011b). A discussion on chitin content can be found in the recent review by Hamed et al. (2016).

From a structural point of view, both chitin and cellulose are polymers of monosaccharide made up of $\beta$-(1 $\rightarrow 4)$-2-acetamido-2-deoxy- $\beta$-D-glucopyranose and 
Table 2.3 Sources of chitin and chitosan in aquatic organisms, terrestrial organisms and microorganisms

\begin{tabular}{|c|c|c|c|c|c|}
\hline $\begin{array}{l}\text { Aquatic } \\
\text { crustaceans }\end{array}$ & $\begin{array}{l}\text { Other sea } \\
\text { animals }\end{array}$ & Insects & $\begin{array}{l}\text { Mushrooms and } \\
\text { Fungi }\end{array}$ & $\begin{array}{l}\text { Other } \\
\text { microorganisms }\end{array}$ & $\begin{array}{l}\text { Other terrestrial } \\
\text { crustaceans }\end{array}$ \\
\hline $\begin{array}{l}\text { Shrimps } \\
\text { Crabs } \\
\text { Lobsters } \\
\text { Crayfishes } \\
\text { Krill }\end{array}$ & $\begin{array}{l}\text { Squids } \\
\text { Cuttlefishes } \\
\text { Annelida } \\
\text { Mollusca } \\
\text { Coelenterata }\end{array}$ & $\begin{array}{l}\text { Scorpions } \\
\text { Spiders } \\
\text { Brachiopods } \\
\text { Cockroaches } \\
\text { Beetles } \\
\text { Silkworms } \\
\text { Ants } \\
\text { Mosquitoes } \\
\text { Honey bees }\end{array}$ & $\begin{array}{l}\text { Agaricus } \\
\text { bisporus } \\
\text { Auricularia } \\
\text { auriculajudae } \\
\text { Lentinula edodes } \\
\text { Trametes } \\
\text { versicolor } \\
\text { Blastocladiaceae } \\
\text { Ascomydes } \\
\text { Aspergillus niger } \\
\text { Mucor rouxii }\end{array}$ & $\begin{array}{l}\text { Green algae } \\
\text { Brown algae } \\
\text { Yeast } \\
\text { Spores }\end{array}$ & $\begin{array}{l}\text { Nematode } \\
\text { Porcellio scaber } \\
\text { Armadillidium } \\
\text { vulgare }\end{array}$ \\
\hline
\end{tabular}

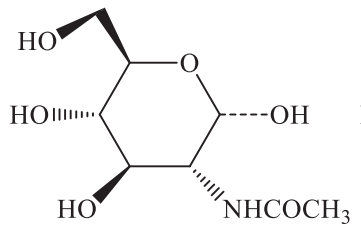

a)

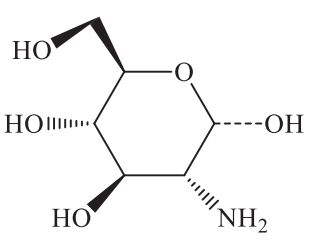

b)

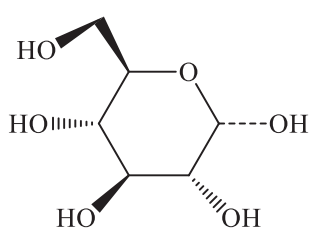

c)

Fig. 2.1 Structure of (a) N-acetyl-glucosamine, monomer of chitin, (b) glucosamine, monomer of chitosan and (c) glucose, monomer of cellulose

$\beta$-(1 $\rightarrow$ 4)-2-deoxy- $\beta$-D-glucopyranose units, respectively (Fig. 2.1). Chitin is generally represented as a linear long-chain homo-polymer composed of $\mathrm{N}$-acetyl glucosamine units, [poly(N-acetyl- $\beta$-D-glucosamine)] (Fig. 2.2). Depending on its source, chitin exists in three different polymorphic forms, namely $\alpha$-, $\beta$ - and $\gamma$-chitin (Bouligand 1965; Neville and Luke 1969a, b; Neville 1975; Neville et al. 1976; Muzzarelli 1977; Roberts 1992a; Horst et al. 1993; Berezina 2016), which can be differentiated by X-ray diffraction, and infrared and NMR spectroscopy (Muzzarelli 1977; Roberts 1992a; Maniukiewicz 2011). $\alpha$-Chitin isomorph is by far the most abundant. The sources for $\alpha$-, $\beta$ - and $\gamma$-chitin are crabs (e.g. Callinectes sapidus, Chionoecetes opilio) and shrimps (Pandalus borealis, Crangon crangon), squids and loligo (Ommastrephes bartrami, Loligo formosana Sasaki), respectively. These forms differ in their arrangement of macromolecular chain. In $\alpha$-chitin, the chains are arranged antiparallel to each other while in $\beta$-chitin they are parallel. In $\gamma$-chitin, the chains are arranged randomly in which two parallel chains and one antiparallel chain form the structure. An update discussion on this topic can be found in the references by Maniukiewicz (2011), Anitha et al. (2014), and Younes and Rinaudo (2015).

Chitin is structurally similar to cellulose: it shares many structural similarities as, for example, the conformation of the monomers and the diequatorial glycosidic 

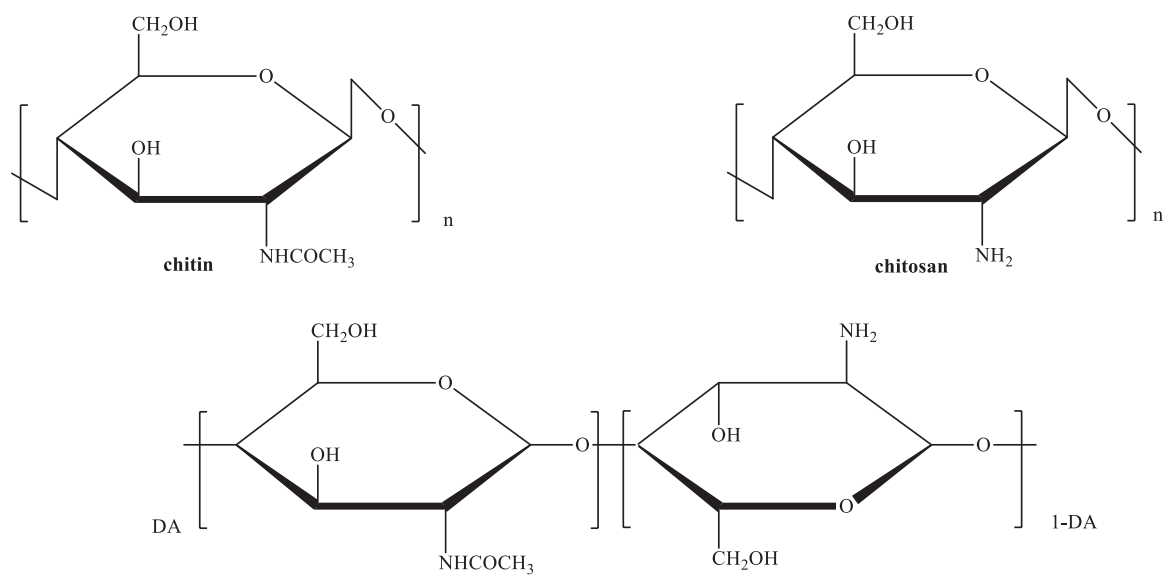

commercial chitosan

Fig. 2.2 Schematic representation of completely acetylated chitin [poly $(N$-acetyl- $\beta$-D-glucosamine], completely deacetylated chitosan [poly(D-glucosamine] and commercial chitosan, a copolymer characterized by its average degree of acetylation (DA) per cent

linkages. Both biopolymers play similar roles since they both act as structural support and defense materials in living organisms. However, chitin is an aminopolymer and has acetamide groups at the $\mathrm{C}-2$ positions in place of the hydroxyl groups in the repeating unit of macromolecular chains (Figs. 2.1 and 2.2). Chitin is also an extremely insoluble material (Austin 1984; Kienzle-Sterzer et al. 1984; Muzzarelli 1977; Muzzarelli et al. 1986b; Skjåk-Braek et al. 1989; Roberts 1992b, c; Hudson and Smith 1998). Despite its huge availability, its insolubility is a major problem that confronts the development of processes and uses of this chitin, and so far, few large-scale industrial uses have been found. For instance, chitin is an effective material for sutures because of its biocompatibility, non-toxicity, biodegradability, antimicrobial activity and low immunogenicity. Chitin also accelerates wound-healing in spray, gel and gauze and it can be used to control drug release (Pillai et al. 2009; Younes and Rinaudo 2015).

More important that chitin is its main derivative, chitosan. Indeed, partial deacetylation of chitin results in the commercial production of chitosan which is a polysaccharide composed by macromolecules of D-glucosamine and $\mathrm{N}$-acetyl glucosamine (Hudson and Smith 1998). The fully deacetylated product is rarely obtained due to the risks of side reactions and chain depolymerization. Chitosans may be considered as a family of linear binary copolymers of $\beta$ - $(1 \rightarrow 4)$-linked $\mathrm{N}$-acetyl glucosamine units and 2-amino-2-deoxy- $\beta$-D-glucose, and do not refer to a uniquely defined polysaccharide, but to products having different proportions of D-glucosamine and $\mathrm{N}$-acetyl glucosamine units and of varying chain lengths. In fact, the "chitosan label" generally corresponds to polymers with less than 25-40\% acetyl content. So, each commercial chitosan is a copolymer characterized by its average degree of acetylation (DA) per cent (Fig. 2.2). This degree of acetylation is 
defined as the percentage DA or fraction $\mathrm{F}_{\mathrm{A}}$ of $\mathrm{N}$-acetylated glycosidic units in chitosan or chitin biopolymer. It is also customary to express this parameter as degree of deacetylation DD $\left(=1-\mathrm{F}_{\mathrm{A}}\right.$ or $=100$-DA per cent $)$. In chitin samples, the degree of acetylation is typically $90 \%$ indicating the presence of some amino groups, as some amount of deacetylation might take place during chitin extraction. Depending on the source, a variable and small proportion of these units are also deacetylated in natural chitin (Peniche et al. 2008). However, this remains always a subject of debate (Peniche et al. 2008; Pillai et al. 2009; Younes and Rinaudo 2015).

\subsubsection{Production}

Although chitin is found in many aquatic organisms, in many insects, in terrestrial crustaceans, in mushrooms, and in some fungi, from a production point of view, the raw biopolymer chitin is only commercially extracted from marine crustaceans primarily because a large amount of wastes/biowastes is available as low-cost byproducts of seafood processing industry (Truong et al. 2007; Nwe et al. 2011b, 2014; Dave and Routray 2018). Shrimps, crabs, lobsters, krill, and squid biowastes from marine industry are the major resources used for the large-scale production of chitin and chitosan. The shells of these marine crustaceans contain $15-40 \%$ chitin, proteins (20-40\%) and calcium carbonate (20-50\%) being two other major components. Pigments, lipids and other minerals including metals and salts are minor components. Of course, the percentages vary considerably with the species used (quality and freshness of shell) and the season (Peniche et al. 2008; Nwe et al. 2014). Other possible sources from marine organisms of chitin production include clams and oysters. Figure 2.3 shows a simplified representation of preparation of chitin, chitosan and their derivatives from aquatic crustacean biowastes. The shells are first ground to the appropriate size and washed profusely with water to remove any organic material adhered to their surface (Acosta et al. 1993). To isolate chitin from the shells of shrimps and crabs, and bone plates of squids, three main steps are then required, namely deproteinization, demineralization, and decolorization. The order of the first two steps is considered irrelevant if protein or pigment recovery is not an objective (Peniche et al. 2008; Nwe et al. 2011b).

The conventional protocol for chitin production is performed through chemical processes using inorganic strong alkali for protein extraction at a given temperature, usually $50-60^{\circ} \mathrm{C}$, and acids for removal of inorganic components, and oxidants for decolorization. These processes permit to dissolve inorganic salts, mainly calcium carbonate and calcium phosphate, using hydrochloric acid and proteins using sodium hydroxide, to eliminate lipids and pigments (melanins, carotenoids), and to obtain a colorless commercial product. The considerable quantities of carotenoids can be used as fish food additives. Calcium carbonate can be converted to calcium oxide and sodium carbonate. The proteins extracted can be recovered by lowering the $\mathrm{pH}$ of the solution to its isoelectric point for precipitation. The recovered proteins can be also used as a high-grade additive for livestock starter feeds. This 


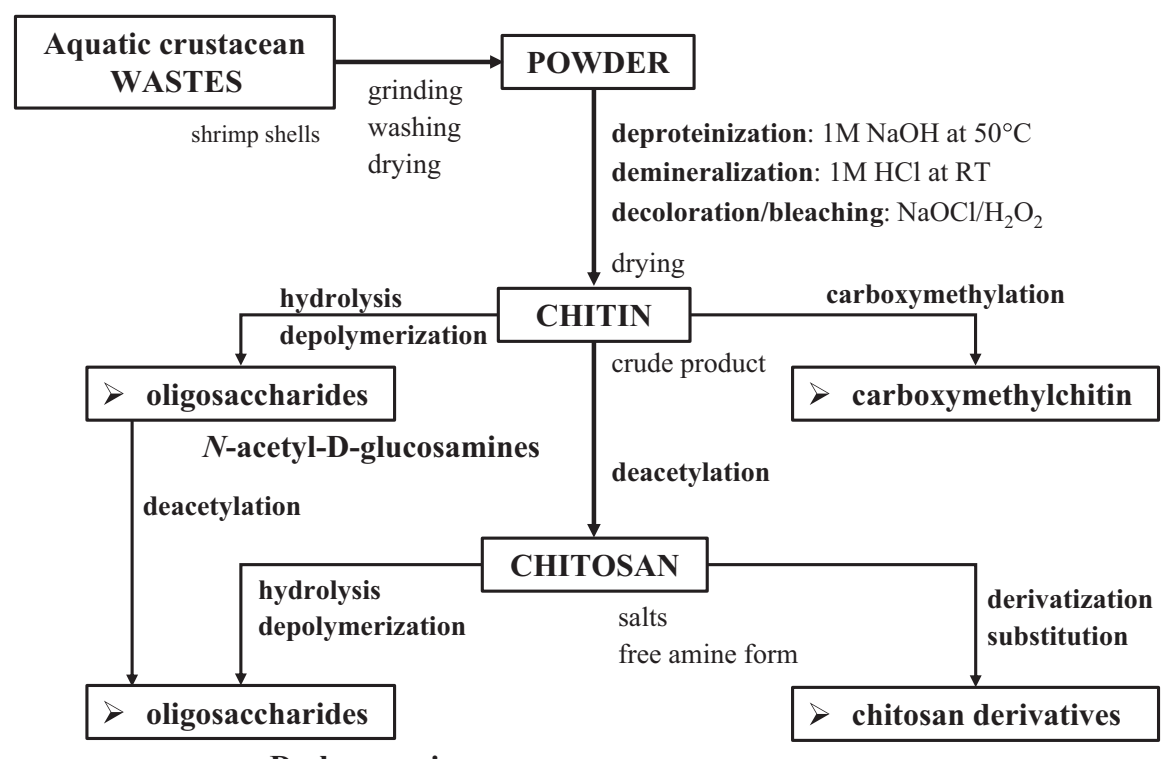

D-glucosamines

Fig. 2.3 Simplified representation of preparation of chitin, chitosan and their derivatives from aquatic crustacean biowastes

decreases the manufacturing costs of chitin. Calcium carbonate is usually eliminated with dilute $\mathrm{HCl}$ solutions at room temperature although other acids have been also studied with success. The acid concentration, reaction time and temperature must be carefully controlled in order to minimize the hydrolytic depolymerization and deacetylation of chitin and/or to prevent thermal degradation (No and Meyers 1995; Percot et al. 2003; Peniche et al. 2008). The color of crustacean shells is due to the presence of pigments such as astaxanthin, cantaxanthin, astacene, lutein and $\beta$-carotene (Acosta et al. 1993; No and Meyers 1995; Kurita 1998). Decolorization/ bleaching is achieved through the use of potassium permanganate or sodium hypochlorite (Kurita 1998, 2006) or by solvent extraction (Acosta et al. 1993; Peniche et al. 2008). Oxidation may attack the free amino groups and introduce modifications in the macromolecules (Acosta et al. 1993). Pigments may be also recovered as high value side products.

Purified chitin is then converted to chitosan by hydrolysis of acetamide groups of chitin using sodium hydroxide solutions 40\%-60\% v/v (No and Meyers 1995; Kurita 1998). The deacetylation process de-esterifies the $\mathrm{N}$-acetyl linkages. Generally, the reaction is carried out under $\mathrm{N}_{2}$ atmosphere or in the presence of a scavenger of oxygen to avoid depolymerization and to prevent chain degradation. The specific reaction conditions depend on several factors such as the origin of the raw material, the previous treatment and the desired degree of acetylation. Deacetylation of chitin is undertaken using homogeneous or heterogeneous processes (Fig. 2.4). Homogeneous deacetylation is achieved with more moderate 


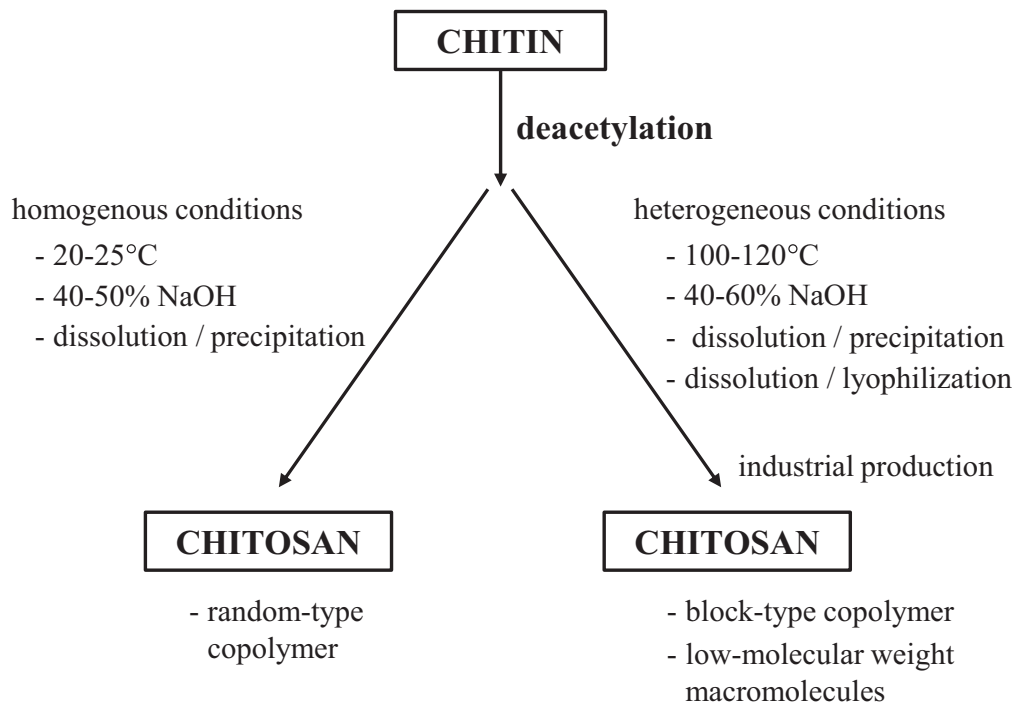

Fig. 2.4 Deacetylation of chitin using homogeneous and heterogeneous processes

alkali concentrations at room temperature and chitosans obtained do not exhibit chain compositional dispersion while chitosans obtained by the heterogeneous process are polydispersed in terms of degree of acetylation of their chains and distribution. High temperatures are preferred for industrial chitosan production (Kurita 1986, 1998, 2006). The chitosan obtained is finally dried into flakes, and then dissolved in acetic acid and filtered to remove extraneous materials resulting in a water-soluble salt. To purify it, the product is dissolved in excess acid and filtered using porous membranes. Adjusting the $\mathrm{pH}$ of the solution to ca. 7.5 by $\mathrm{NaOH}$ causes flocculation due to the deprotonation and the insolubility of the macromolecule chains at neutral $\mathrm{pH}$. The sample is then washed with water and dried. Data published on worldwide chitosan market is estimated to be over 40,000 metric tons in 2018 (Philibert et al. 2017).

The chemical methods for chitin/chitosan production from biowastes are widely used for industrial purposes due to their low cost and suitability to mass production (Nwe et al. 2014; Younes and Rinaudo 2015). However, their production leads to inconsistent physicochemical characteristics of products, e.g. different grades of quality, protein contamination, different levels of degree of acetylation and inconsistent molecular weight, because of seasonal, climate and variable supply of raw materials, e.g. quality of the shell, species nature, as well as macromolecular variability and difficulties of process conditions: long processing times, toxicity of reactants, as previously reported by No and Meyers (1995). This results in a wide unpredictable range of properties and this is a major concern for the use of crustacean chitosan in the medical and pharmaceutical fields.

Another often cited issue is the fact that the extraction processes are not ecological. The industrial methods consume high amounts of water and energy, use large 
amounts of alkali, and generate large quantities of hazardous chemical wastes. To overcome these problems, alternatives to the chemical production of chitin and chitosan are the biological treatments such as microbial production and enzymatic hydrolysis (Kurita 1998, 2006; Kim 2011; Jo et al. 2011; Philibert et al. 2017). Actually, the biotechnology fermentation process of chitin from crustacean wastes is proposed on an industrial scale. However, the proteins and minerals are not completely removed by the biological treatment. Other drawbacks are a lower quality and a higher cost compared with the industrial, chemical process. The fermentation processes offer, however, new perspectives for the production of chitosan. Microorganisms and terrestrial organisms like insects, terrestrial crustaceans, and mushrooms were also considered as alternative sources for the large-scale production of chitin and chitosan. In particular, the biotechnological production of chitin/ chitosan from microbial sources appears promising because the products obtained are pure with specific characteristics. However, the yield of purified chitin and chitosan from these sources is lower than that of aquatic crustacean sources. Different preparation methods often result in differences in the degree of acetylation, distribution of acetyl groups, chain length (molecular weight) and conformational structure of chitin and chitosan. In addition, although significant efforts have been made to optimize the fermentation process for the production of these two biopolymers, the technology may still be significantly improved. For more details on the chitin/chitosan production, the following reviews can be consulted: Muzzarelli et al. 1986a; Skjåk-Braek et al. 1989; Horst et al. 1993; Kurita 1998; Rinaudo 2006; Nwe et al. 2011a, b, 2013, 2014; Younes and Rinaudo 2015; Philibert et al. 2017.

\subsubsection{Nomenclature of Chitin and Chitosan}

Nowadays, chitosan and chitin are known as copolymers of D-glucosamine and $\mathrm{N}$-acetyl-D-glucosamine units, characterized by their average degree of acetylation or degree of deacetylation. However, the nomenclature of chitin and chitosan remains always a subject of debate. Until the end of 1990s, it was agreed to define chitin and chitosan as polymers with degree of acetylation more than $40 \%$ and less than 40\%, respectively (Peters 1995). In the 2000s, Eugene Khor (National University of Singapore) defined that "when the number of $\mathrm{N}$-acetyl glucosamine units is higher than $50 \%$, the biopolymer is termed chitin; conversely, when the number of D-glucosamine units is higher, the term chitosan is used" (Khor 2001; Khor and Lim 2003). In 2008, George AF. Roberts (Nottingham University, UK) proposed to develop a nomenclature system and to characterize chitin and chitosan with their mole fraction of D-glucosamine or $\mathrm{N}$-acetyl glucosamine (source: European Chitin Society). In 2011, Nitar Nwe (Kansai University, Japan) also proposed to develop a systematic nomenclature system for chitin and chitosan products (Nwe et al. 2011a, b).

Chitin and chitosan can be also defined on the basis of their differences in solubility in water. Chitosan is soluble in aqueous acetic acid while chitin is insoluble 
and also in the vast majority of common solvents. This is the reason why chitin was considered an intractable polymer and for many years, it remained mainly a laboratory curiosity (Peniche et al. 2008). Based on the solubility properties of products in acid and alkaline solutions, the name of chitin and chitosan was previously given by Odier in 1823 and Hoppe-Seiler in 1894, respectively. Because of its high cohesive energy related to strong intra- and intermolecular interactions through hydrogen bonds, commercial chitin like cellulose is difficult to dissolve.

Chitin also possesses a low content of amino groups, and therefore, its macromolecules are not soluble in water and do not swell in common solvents, except $\beta$-chitin. Chitosan has a rigid crystalline structure through intra- and inter-molecular hydrogen bonding. However, it is soluble in acidic media, except in benzoic acid and in oxalic acid. Indeed, in contrast to chitin, the presence of free amino groups on the C-2 position of the D-glucosamine unit along the macromolecule chains allows chitosan to dissolve in dilute aqueous acidic solvents through the protonation of these groups and the formation of the corresponding polymer salt. The biopolymer is then converted to a polyelectrolyte in acidic media. Nowadays, the nomenclature described in Table 2.4 is accepted. However, as discussed by Nwe and collaborators, "Do all type of chitosans with 45-50\% degree of acetylation dissolve in water?" The answer to this question is not yet clear (Nwe et al. 2011b).

\subsubsection{Characterization}

Each commercial batch of chitosan is characterized by its degree of acetylation or degree of deacetylation, molecular weight, and others specific characteristics such as appearance of product, purity, crystallinity, solubility, turbidity of polymer solution, ash content, etc. (Nwe et al. 2014; Younes and Rinaudo 2015). These characteristics are of major importance on applications of these products. Several reviews can be consulted on these different aspects of chitosan characterization (Table 2.1). Commercial industrial or technical chitosans are usually offered as flakes or powders with prices ranging from 15 to $100 \mathrm{US} \$ / \mathrm{kg}$, depending mainly on degree of

Table 2.4 Nomenclature of chitin and chitosan

\begin{tabular}{l|l|l|l}
\hline Product & Characteristics & $\begin{array}{l}\text { Degree of } \\
\text { deacetylation }\end{array}$ & $\begin{array}{l}\text { Molecular } \\
\text { weight }\end{array}$ \\
\hline Chitin & $\begin{array}{l}\text { Insoluble in alkaline solution } \\
\text { Insoluble in dilute organic acids }\end{array}$ & $>50 \%$ & $>5 \mathrm{kDa}$ \\
\hline Chitosan & $\begin{array}{l}\text { Insoluble in alkaline solution } \\
\text { Soluble in dilute organic acids } \\
\text { Precipitation in solution with } \\
\text { alkaline pH }\end{array}$ & $<50 \%$ & $>5 \mathrm{kDa}$ \\
\hline $\begin{array}{l}\text { Chito- } \\
\text { oligosaccharide } \\
\text { Oligochitosan }\end{array}$ & $\begin{array}{l}\text { Soluble in alkaline solution } \\
\text { Soluble in acid solution } \\
\text { Soluble in neutral media }\end{array}$ & All & $<5 \mathrm{KDa}$ \\
\hline
\end{tabular}


acetylation/degree of deacetylation and purity parameters and specifications of products, e.g. appearance, viscosity, ash content, and metal content lower than $10 \mathrm{mg} / \mathrm{kg}$. An ultrapure grade chitosan, e.g. with low levels of heavy metals, total metals, bacteria, ash, and of protein, and with no bleaching step during extraction and purification processes, for biomedical applications can cost upward of US\$ 20,000/kg (Fig. 2.5). Several companies also offer chitosan as bead forms.

The main characteristic of a commercial sample is its average degree of acetylation. The most convenient method for the determination of the degree of acetylation for soluble samples is ${ }^{1} \mathrm{H}-\mathrm{NMR}$ spectroscopy (Hirai et al. 1991; Vårum et al. 1991, 1992; Rinaudo 2006; Kasaai 2008, 2009, 2011). The value is calculated from the integral ration between proton of acetyl group of $\mathrm{N}$-acetyl glucosamine and the protons of D-glucosamine. Other methods include solid state NMR, FT-IR, Raman spectroscopy, UV spectroscopy, circular dichroism, potentiometry, conductimetry, hydrolytic and enzymatic techniques (Focher et al. 1992; Raymond et al. 1993; Rinaudo et al. 1997; Peniche et al. 2008; de Alvarenga 2011). The degree of acetylation of a sample is an important factor influencing its physical and chemical properties: solubility, flexibility and polymer conformation, viscosity, crystallinity, conductivity, tensile strength and photoluminescence. It also influences the biological properties of chitosan: biodegradability, biocompatibility, mucoadhesion, hemostatic, analgesic, adsorption enhancer, antimicrobial, anticholesterolemic, and antioxidant.

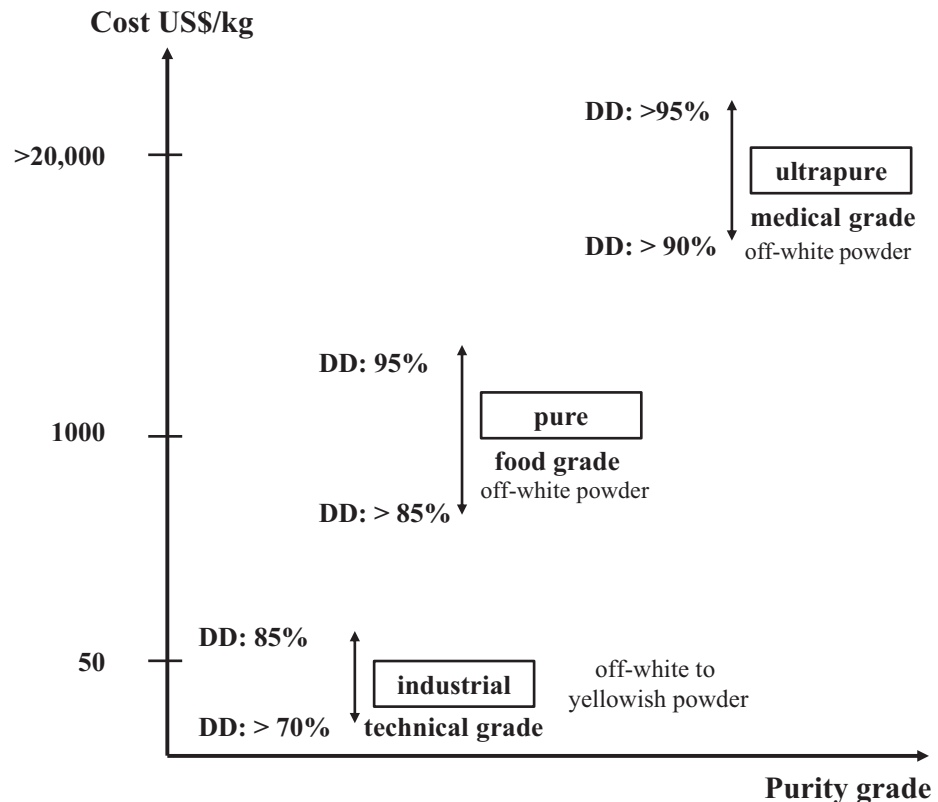

Fig. 2.5 Cost-purity relationship of chitosans (DD: degree of deacetylation) 
Another important characteristic to consider is the molecular weight of each sample, after dissolution, and its distribution. This parameter influences on the viscosity of aqueous solution of chitosan and has also a significant role not only on the chitosan properties but also in the industrial applications in many fields. For example, in medical and agricultural domains, low-molecular weight chitosans are preferred (Nwe et al. 2011b). The most relevant technique used for molecular weight determination is viscosimetry. Other techniques such as gel permeation chromatography, light scattering and osmometry (Rinaudo et al. 1997; Peniche et al. 2008; Kasaai 2011) can be used. Polysaccharides are in general polydisperse with respect to molecular weight, and chitosan products are no exception. The molecular weight of a sample is thus an average over the whole distribution of molecular weights. Each sample can be characterized by a polydispersity index (Rinaudo 2006; Peniche et al. 2008). An important step in chitosan characterization is also the distribution of acetyl groups along the macromolecular chain. Indeed, this may influence the solubility of the sample and the inter-chain interactions (Younes and Rinaudo 2015). This distribution can be evaluated using ${ }^{13}$ C-NMR spectroscopy (Vårum et al. 1991, 1992; Kasaai 2011).

The degree of acetylation and molecular weight are undoubtedly the most important parameters to establish the physical and chemical identity of chitin and chitosan products. These parameters have an important effect of the physical, chemical and biological properties of products. However, both parameters vary with the source of the raw material and the preparation method. In addition, they dictate the functional and technological properties of these biopolymers. Other properties such as solubility, viscosity, and gelling capacity are also dependent on these two parameters (Gunjal et al. 2004; Rinaudo 2006; Nwe et al. 2011a, b, 2014).

\subsubsection{Properties}

Chitosan presents multiple physical-chemical, biological and technological properties as reported in Table 2.5. The main property of chitosan is its cationic nature and its particular behavior in solution. Indeed, this biopolymer is the only natural cationic polymer in the nature (Muzzarelli and Muzzarelli 2005; Rinaudo 2006). Figure 2.6 illustrates chitosan's versatility in aqueous solution. At low pH, usually less than about 6.3 , chitosan's amine groups are protonated conferring polycationic behavior to polymer while at higher $\mathrm{pH}$ (above 6.3), chitosan's amine groups are deprotonated and reactive. Usually, chitosan becomes soluble in all aqueous acidic media when the average degree of acetylation is lower than $50 \%$. Chitosan is soluble in dilute inorganic acids such as $\mathrm{HCl}, \mathrm{HBr}, \mathrm{HNO}_{3}$ and $\mathrm{HCLO}_{4}$, in concentrated $\mathrm{H}_{2} \mathrm{SO}_{4}$, in organic acids, e.g. acetic, citric, formic, lactic, and in organic solvents: tetrahydrofuran, ethyl-acetate, 1,2-dichlorethane. Acetic and formic acids are the most commonly used for solubilization of chitosan. However, the solubility is a difficult parameter to control because it is related to the degree of acetylation, the ionic concentration, the $\mathrm{pH}$ of the solution used, the nature of the acid used for 
Table 2.5 Intrinsic physical-chemical, biological and technological properties of chitosan

\begin{tabular}{|c|c|}
\hline Physical-chemical properties & Selected references \\
\hline $\begin{array}{l}\text { Biopolymer with rigid D-glucosamine } \\
\text { structure containing numerous amino/ } \\
\text { hydroxyl groups } \\
\text { Linear amino-polysaccharide with high } \\
\text { nitrogen content, hydrophilicity and high } \\
\text { crystallinity } \\
\text { Two grades of high and low molecular } \\
\text { weight } \\
\text { Three main grades of purity: technical, } \\
\text { pure and ultra-pure } \\
\text { Reactive amino/hydroxyl groups for } \\
\text { physical modification, chemical activation } \\
\text { or enzymatic modification: high reactivity } \\
\text { Weak base, powerful nucleophile: pK } \\
\text { 6.3 } \\
\text { Soluble in dilute acidic aqueous solutions } \\
\text { Insoluble in water and organic solvents } \\
\text { Forms salts with organic and inorganic } \\
\text { salts } \\
\text { Water retention } \\
\text { Capacity to form hydrogen bonds and } \\
\text { chemical interactions } \\
\text { Aggregation behavior } \\
\text { Electrostatic, chelating and complexing } \\
\text { properties } \\
\text { Surface active properties } \\
\text { Ionic conductivity } \\
\text { Rheological behavior }\end{array}$ & $\begin{array}{l}\text { Muzzarelli et al. (1986a, b), Roberts (1992a), } \\
\text { Winterowd and Sandford (1995), No and Meyers } \\
\text { (1995), Kim et al. (1999), Viney and Harish (2002), } \\
\text { Vårum and Smidsrød (2004b), Yilmaz (2004), } \\
\text { Shahidi and Abuzaytoun (2005), Rinaudo (2006), } \\
\text { Rauh and Dornish (2006), Peniche et al. (2008), } \\
\text { Elsabee et al. (2009), Sahoo and Nayak (2011), } \\
\text { Teng (2012), Sashiwa and Harding (2015), Annu } \\
\text { et al. (2017), and Tripathi and Singh (2018) }\end{array}$ \\
\hline Biological properties & Selected references \\
\hline $\begin{array}{l}\text { Non-toxicity } \\
\text { Biocompatibility; not digestible by } \\
\text { humans: dietary fiber } \\
\text { Biodegradability } \\
\text { Hydrating agent } \\
\text { Encapsulating material, } \\
\text { microencapsulation } \\
\text { Delivery systems and drug releasing } \\
\text { activity; carriers and immunoadjuvants in } \\
\text { vaccine delivery } \\
\text { Bioactivities: analgesic effect, } \\
\text { antimicrobial (antibacterial, antifungal), } \\
\text { antioxidant, anti-inflammatory, anti-acid, } \\
\text { antiulcer, anticoagulant, antihypertensive, } \\
\text { hypolipidemic, antidiabetic, anticancer, } \\
\text { antitumor, anti-HIV, bioadhesivity } \\
\text { Abilities: healing, self-healing, wound } \\
\text { healing; mucoadhesion, bone regeneration, } \\
\text { immuno-adjuvant }\end{array}$ & $\begin{array}{l}\text { Peniche et al. (2003), Rabea et al. (2003), Vårum } \\
\text { and Smidsrød (2004b), Shahidi and Abuzaytoun } \\
\text { (2005), Rinaudo (2006), Goy et al. (2009), } \\
\text { Friedman and Juneaj (2010), Dash et al. (2011), } \\
\text { Kim and Kim (2011), Vyas et al. (2011), Ta et al. } \\
\text { (2011), Dutta and Dutta (2011), Je and Ahn (2011), } \\
\text { Yamazaki and Hudson (2012), Fernandez-Saiz } \\
\text { (2012), Estevinho et al. (2013), Karadeniz and Kim } \\
\text { (2014a, b), Moratti and Cabral (2017), } \\
\text { Tachaboonyakiat (2017), Verlee et al. (2017), } \\
\text { Vunain et al. (2017), Jardine and Sayed (2018), } \\
\text { Perinelli et al. (2018), Sharif et al. (2018), Singh } \\
\text { et al. (2018), Tripathi and Singh (2018), and } \\
\text { Vasconcelos and Pomin (2018) }\end{array}$ \\
\hline
\end{tabular}


Table 2.5 (continued)

\begin{tabular}{l|l}
\hline Technological properties & Selected references \\
\hline $\begin{array}{l}\text { Polyelectrolyte at acidic pH; cationic } \\
\text { biopolymer with high charge density at } \\
\text { pH < 6.3: one positive charge per }\end{array}$ & $\begin{array}{l}\text { Muzzarelli et al. (1986b), Sandford (1989), No and } \\
\text { glucosamine residue }\end{array}$ \\
$\begin{array}{l}\text { Mnteraction with negatively charged } \\
\text { Smidsrød (2004b), Shahidi and Abuzaytoun (2005), } \\
\text { molecules; adheres to negatively charged } \\
\text { surfaces }\end{array}$ & Hamman (2010), Mati-Baouche et al. (2014), and \\
Adhesivity/Bioadhesivity & \\
$\begin{array}{l}\text { Film-forming ability } \\
\text { Versatility: solutions, biosorbent, fibers, films }\end{array}$ & \\
Gelation ability; viscosity: high to low \\
$\begin{array}{l}\text { Coagulating agent / Flocculating agent } \\
\text { Entrapment and adsorption properties }\end{array}$ \\
$\begin{array}{l}\text { Filtration and separation } \\
\text { Materials for isolation of biomolecules }\end{array}$ \\
\hline
\end{tabular}
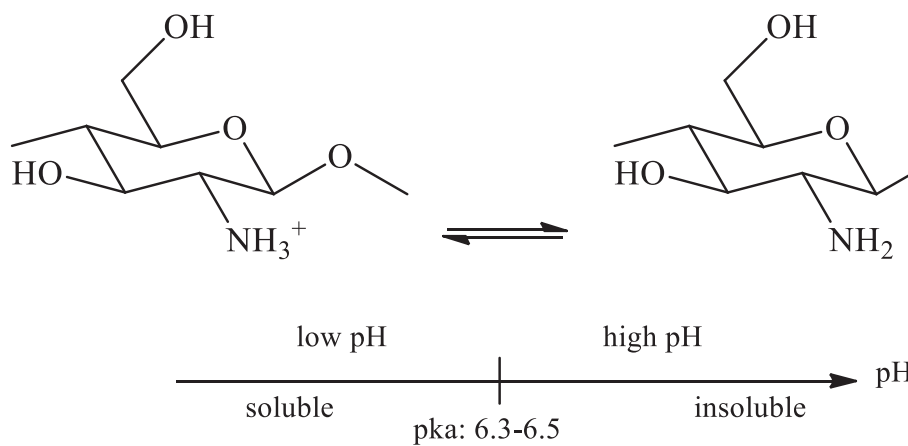

Fig. 2.6 Schematic illustration of chitosan's versatility in aqueous solution: at low pH, less than $\mathrm{pK}_{\mathrm{a}}$, chitosan's amines are protonated conferring polycationic behavior to macromolecules; at higher $\mathrm{pH}$, above $\mathrm{pK}_{\mathrm{a}}$, chitosan's amines are deprotonated and also reactive (useful for derivatization, substitution, etc.); in the latter case, chitosan can undergo associations that can lead to networks such as gels and films to fibers

protonation, and also the distribution of acetyl groups along the macromolecular chain, the latter depending on the conditions of production of chitosan.

The protonation reaction is interesting because, after dissolution, chitosan can be precipitated into beads, cast into films and membranes, spun into fibers or nano-fibers, and also crosslinked to produce fibers or sponges. The processing of chitosan is easier than that of chitin. However, the stability of the products is lower due to the larger hydrophilic character and the $\mathrm{pH}$ sensitivity. For better stability, chitosan may be crosslinked using epoxides or glutaraldehyde. Composites and blends are also produced taking advantage of the polycationic properties of chitosan in acidic conditions.

The polyelectrolyte character of chitosan greatly influences its solution properties. There is an interesting structure-property relationship in chitosan. The excellent previous reviews of Vårum and Smidsrød (2004a), Dash et al. (2011), Younes and Rinaudo (2015), and Sahariah and Másson (2017) can be referred to on these 
subjects. As a polyelectrolyte, chitosan is able to form electrostatic interactions useful for example in wastewater treatment and presents film-forming capacity and bioadhesivity, properties used in packaging and edible films. These electrostatic interactions are also applied for preparation of layer-by-layer polyelectrolyte capsules or films. The behavior of chitosan in solution is also important for medical applications. Its characteristic features such as being cationic, hemostatic and insoluble at high $\mathrm{pH}$ can be reversed by sulfating the amine groups which makes the macromolecule anionic and water-soluble, with the introduction of anticoagulant properties. The presence of the amino groups allows to explain most of chitosan biological properties (Domard and Domard 2001; Vårum and Smidsrød 2004a; Kumirska et al. 2011). Its mucoadhesion can be explained by the interaction between the negatively charged residues in the mucin - the glycoprotein that composes the mucus - and the amino groups positively charged. The hemostatic activity of chitosan can also be related to its cationic character. Red blood cell membranes charged negatively can interact with the positively charged chitosan chains. Besides, chitin shows less effective haemostatic activity than chitosan, confirming this explanation. The polycationic nature of chitosan also allows explaining chitosan analgesic effects. Other examples can be found in the reviews by Croisier and Jérôme (2013), Younes and Rinaudo (2015), and Sahariah and Másson (2017). The facile derivatization also makes chitosan an ideal candidate for the synthesis of biomaterials with specific functionality.

\subsubsection{Biodegradation and Toxicity of Chitosan}

Chitosan (CAS No. 9012-76-4) is widely regarded as being a non-toxic, biologically compatible, and eco-friendly product (Roberts 1992b; Illum 1998; Thanou et al. 2001; Kean and Thanou 2010). It is approved for excipients, food and dietary applications, and in weight-loss products in Japan, Korea, Italy and Finland. It has been approved by the US Food Drug Administration for use in wound dressing, bandages and hemostatic agents (Illum 1998; Felt et al. 1998; Singla and Chawla 2001; Kato et al. 2003; Illum and Davis 2004; Kean and Thanou 2010; Badwan et al. 2015).

Enzymatically, chitosan can be degraded by enzymes able to hydrolyze glucosamine linkages (Dash et al. 2011). Chitosan is known to be degraded in vertebrates predominantly by lysozyme and by certain bacterial enzymes in the colon. Given adequate time and appropriate conditions, chitosans, in most cases would degrades sufficiently to be excreted. However, as already discussed, the term chitosan represents a large group of structurally different chemical entities that may show different specific characteristics (degree of acetylation, molecular weight, ash content), and biodegradation and toxicological profiles. In addition, chitosan modifications, e.g. by derivatization or cross-linking reactions, could make it more or less toxic and any residual reactants should be carefully removed.

An interesting discussion on these topics can be found in the comprehensive review by Kean and Thanou (2010). These authors concluded that regulatory 
agencies encounter many difficulties in approving all existing chitosan-based products as generally regarded as safe (GRAS) materials. Younes and Rinaudo (2015) pointed out that, for biomedical applications, chitin and chitosan need to be highly purified since residual proteins and pigments can cause side effects. Sadler and Funnell (2018) recently discussed the authorized EU health claim for chitosan in relation to its role in the maintenance of normal blood cholesterol levels. Due to the associated risk of elevated blood cholesterol levels with cardiovascular disease, the development of food and beverage products that can help to maintain healthy blood cholesterol concentrations was potentially beneficial to public health. Their review discusses the approved health claim for chitosan, describes the scientific evidence that substantiates the claim, considers how this claim could be used in practice and the consumer perception of health claims.

\subsubsection{Derivatives}

As already mentioned, chitin is water-insoluble and chitosan exhibits a limitation in its solubility in water and reactivity. The poor solubility of unmodified chitosan in organic solvents also make its utilization limited. Therefore, many studies have paid attention to modify their chemical structure (Austin 1984; Kienzle-Sterzer et al. 1984; Muzzarelli et al. 1986b; Skjåk-Braek et al. 1989; Roberts 1992b, c; Zhang et al. 1993; Hudson and Smith 1998). Often, the methods of modification are adapted from the cellulose world (Muzzarelli et al. 1986c; Kurita 2001, 2006; Rinaudo 2006; Harish Prashanth and Tharanathan 2007; Mourya and Inamdar 2008; Kim and Venkatesan 2014). Chitosan has three types of reactive functional groups: two hydroxyl groups on C-3 and C-6 in each repeating unit and one amino group on $\mathrm{C}-2$ in each deacetylated unit (Fig. 2.1). These groups allow the conjugation of many substituents resulting in new modified derivatives (Fig. 2.7). The main reactions are quaternization (useful to increase the solubility of chitosan in neutral water), acetylation, reductive amination, acylation, phosphorylation, Schiff's bases, and crosslinking modifications (Austin 1984; Kienzle-Sterzer et al. 1984; Kurita 1986, 1998, 2006; Muzzarelli et al. 1986b, c; Skjåk-Braek et al. 1989; Roberts 1992b, c; Hudson and Smith 1998; Kurita 2001, 2006; Harish Prashanth and Tharanathan 2007; Thakur and Thakur 2014; Wang et al. 2016). The main derivatives are quaternary ammonium chitosan salts, carboxymethyl-chitosans, carboxyalkyl-chitosans, arylchitosans, hydroxyalkyl-chitosans, sulfated derivatives, phosphorylated chitosan, succinyl-chitosan, and thiolated chitosans (Sashiwa and Aiba 2004; Jayakumar et al. 2006, 2007; Alves and Mano 2008; Mourya and Inamdar 2008). Two update reviews have been compiled by Argüelles-Monal et al. (2018) and Yu et al. (2018). ArgüellesMonal et al. (2018) discussed the latest advances in methods and strategies of chitosan functionalization such as the click chemistry approach. Table 2.6 shows some chitosan derivatives and their potential applications. Carboxymethyl-chitosans are the most fully explored derivatives of chitosan. Under controlled reaction conditions, many products can be obtained with different selectivity (Fig. 2.8) and degree 


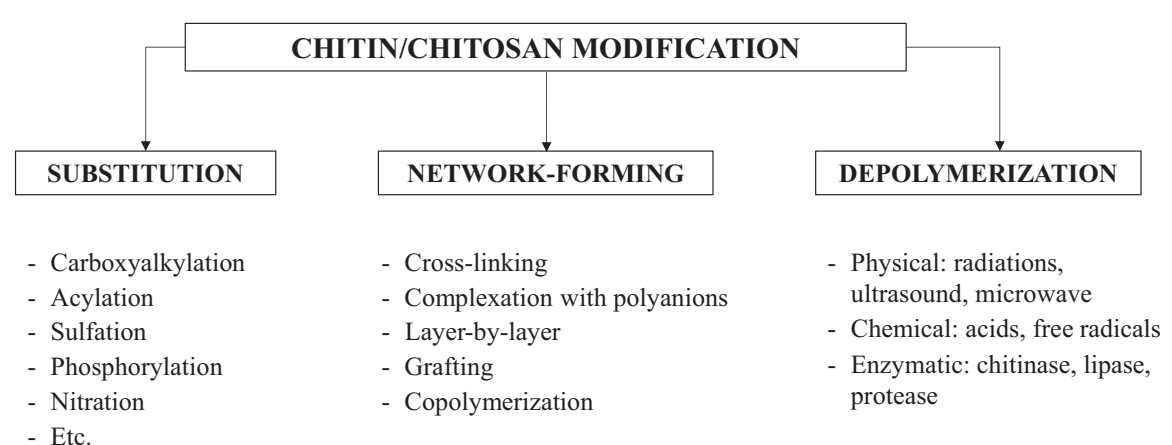

Fig. 2.7 Multifaceted modification potential of chitin and chitosan biopolymers

of substitution. The graft copolymerization of chitosan with particular emphasis on atom transfer radical polymerization as a new strategy to prepare new materials has been discussed by Thakur and Thakur (2014). The authors described the synthesis, characterization, and multifunctional applications of many types of chitosan-based copolymers. They concluded that the technique is promising to incorporate the desired functionalities in chitosan for targeted applications. However, future research needs to look into a better understanding of the structure and chemistry of different polymerization reactions. Wang et al. (2012) also reported that graft copolymerization of chitosan is an alternative route to prepare derivatives for target applications.

Numerous studies have been also conducted to transform the biopolymers chitin and chitosan into low molecular weight chitosans or oligosaccharides using physical, chemical, electrochemical and/or biotechnological processes (Liang et al. 2018; Mourya and Inamdar 2008). Cleavage of glycosidic bonds leads to production of oligomers with important variations in the degree of polymerization (chain lengths). These low molecular weight oligosaccharides, known as chitooligosaccharides, abbreviated COS, or oligochitosans (chitosan oligomers, chitooligomers) present low viscosity and relatively small molecular sizes which in turn make them water soluble and having versatile biological activities such as readily adsorbed in vivo, cholesterol lowering, antibacterial and antitumor effects (Hamed et al. 2016; Liaqat and Eltem 2018). They are also soluble in solutions at acid and alkaline $\mathrm{pH}$. Indeed, these products have a remarkably widespread range of biological activities and own an important potential for numerous industrial applications. In target applications such as biomedicine, cosmetics and agriculture, e.g. as antibacterial agent or for plant growth stimulator, low molecular weight chitosans and oligomers are more effective than high-molecular weight chitosans (Peniche et al. 2008; Nwe et al. 2014). Low molecular weight chitosans or oligosaccharides can be obtained from high-molecular weight chitosans by physical, e.g. gamma-ray irradiation, microwave treatment or ultrasonic method, mechanical method (sonication), chemical treatment (oxidation, hydrolysis) using acids or free radicals $\left(\mathrm{HCl}, \mathrm{H}_{2} \mathrm{O}_{2}, \mathrm{HNO}_{2}\right.$ ) or enzymatic method using specific or non-specific enzymes, e.g. chitinase, chitosanase, cellulases, lipases, lysozyme, and protease (Liaqat and Eltem 2018; Liang 
Table 2.6 Chitosan derivatives and examples of applications

\begin{tabular}{|c|c|c|c|}
\hline $\begin{array}{l}\text { Some chitosan } \\
\text { derivatives }\end{array}$ & $\begin{array}{l}\text { Important } \\
\text { properties and } \\
\text { comment }\end{array}$ & Application & References \\
\hline \multicolumn{4}{|c|}{ Carboxymethyl-chitosans } \\
\hline $\begin{array}{l}\text { O-carboxymethyl- } \\
\text { chitosan } \\
\text { N-carboxymethyl- } \\
\text { chitosan } \\
\text { O,N-carboxymethyl- } \\
\text { chitosan } \\
\text { N,N-carboxymethyl- } \\
\text { chitosan } \\
\text { n-Lauryl- } \\
\text { carboxymethyl- } \\
\text { chitosan }\end{array}$ & \begin{tabular}{|l|} 
The most fully \\
explored derivatives \\
of chitosan \\
Amphoteric \\
products \\
Water soluble in a \\
wide range of pH \\
The solubility \\
depends on pH \\
Film- and \\
gel-abilities \\
Clarifying agent
\end{tabular} & \begin{tabular}{|l|} 
Fruit preservation \\
Plant protection \\
Excipients \\
Drug delivery \\
systems \\
Dental care \\
Carriers for \\
hydrophobic cancer \\
drugs \\
Cosmetics \\
Surfactants \\
Beverage industry \\
(clarification) \\
Cotton fabric
\end{tabular} & $\begin{array}{l}\text { Mourya and Inamdar (2008), } \\
\text { Elsabee et al. (2009), } \\
\text { Jimtaisong and Saewan } \\
\text { (2014), Tastan and Baysal } \\
\text { (2015), Rocha et al. (2017), } \\
\text { Sahariah and Másson (2017), } \\
\text { Verlee et al. (2017), and } \\
\text { Farion et al. (2018) }\end{array}$ \\
\hline \multicolumn{4}{|l|}{ Chitosan 6-O-sulfate } \\
\hline $\begin{array}{l}\text { O-sulfated chitosan } \\
\mathrm{N} \text {-sulfated chitosan } \\
\text { 2-N,6-O- sulfated } \\
\text { chitosan } \\
\text { N-butyl-O-sulfate } \\
\text { chitosan } \\
\text { N-octyl-O-sulfate } \\
\text { chitosan } \\
\text { N-palmitoyl-O-sulfate } \\
\text { chitosan }\end{array}$ & $\begin{array}{l}\text { Structural analogy } \\
\text { to heparin: } \\
\text { 2-N,6-O- sulfated } \\
\text { chitosan } \\
\text { Anticoagulant } \\
\text { activity } \\
\text { Antimicrobial agent } \\
\text { Hemostatic agent } \\
\text { Anti HIV-1 activity }\end{array}$ & \begin{tabular}{|l|} 
Drug delivery \\
Blood anticoagulant \\
Hemagglutination \\
inhibition activity \\
Hemo- \\
compatibility \\
Antitumor activity \\
Antioxidant \\
property \\
Tissue engineering \\
Lipoprotein \\
lipase-releasing \\
activity \\
Treatment of \\
neurological \\
diseases neural \\
repair \\
Superplasticizer
\end{tabular} & $\begin{array}{l}\text { Jayakumar et al. (2007), } \\
\text { Elieh-Ali-Komi and Hamblin } \\
\text { (2016), Verlee et al. (2017), } \\
\text { and Yu et al. (2018) }\end{array}$ \\
\hline \multicolumn{4}{|c|}{ Quaternized derivatives } \\
\hline $\begin{array}{l}\mathrm{N} \text {-substituted } \\
\text { quaternary ammonium } \\
\mathrm{N}, \mathrm{N}, \mathrm{N} \text {-trimethyl- } \\
\text { chitosan chloride } \\
\mathrm{N} \text {-(2-hydroxyl) } \\
\text { propyl-3- } \\
\text { trimethylammonium } \\
\text { chitosan chloride }\end{array}$ & $\begin{array}{l}\text { Cationic derivatives } \\
\text { Water soluble in a } \\
\text { wide range of } \mathrm{pH} \\
\text { Interactions with } \\
\text { negatively species } \\
\text { Mucoadhesion } \\
\text { Better moisture } \\
\text { retention and } \\
\text { absorption } \\
\text { compared to } \\
\text { chitosan }\end{array}$ & $\begin{array}{l}\text { Flocculating agent } \\
\text { Use in } \\
\text { papermaking, paper } \\
\text { packaging } \\
\text { Antistatic agent } \\
\text { Antifungal agent } \\
\text { Dental care } \\
\text { Drug delivery, gene } \\
\text { delivery } \\
\text { Gene transfection } \\
\text { Interactions with } \\
\text { cell membranes }\end{array}$ & $\begin{array}{l}\text { Mourya and Inamdar (2008), } \\
\text { Kedjarune-Leggat and } \\
\text { Leggat (2011), Huang et al. } \\
\text { (2014), Muñoz-Bonilla et al. } \\
\text { (2014), LogithKumar et al. } \\
\text { (2016), Pardeshi and } \\
\text { Belgamwar (2016), and } \\
\text { Sahariah and Másson (2017) }\end{array}$ \\
\hline
\end{tabular}


Table 2.6 (continued)

\begin{tabular}{|c|c|c|c|}
\hline $\begin{array}{l}\text { Some chitosan } \\
\text { derivatives }\end{array}$ & $\begin{array}{l}\text { Important } \\
\text { properties and } \\
\text { comment }\end{array}$ & Application & References \\
\hline \multicolumn{4}{|l|}{ Alkylated derivatives } \\
\hline $\begin{array}{l}\text { Hydroxyethyl chitosan } \\
\text { Hydroxypropyl } \\
\text { chitosan } \\
\text { Hydroxybutyl chitosan } \\
\text { Alkyl-glycosides } \\
\text { branched chitosan } \\
\text { N-acyl derivatives } \\
\text { N-carboxyacyl chitosan } \\
\text { N-lauryl derivatives }\end{array}$ & \begin{tabular}{|l|} 
Amphiphilic \\
products \\
Hydrophobic \\
properties \\
Highly substituted \\
derivatives \\
Modifications \\
require multiple \\
protection and \\
deprotection steps \\
Ability to form \\
physical gels, \\
sponges \\
Rapid gelation \\
kinetics \\
Micelle formation \\
High moisture \\
absorption rate \\
Compatible with \\
neutral and cationic \\
surfactants \\
Rheological \\
modifiers
\end{tabular} & $\begin{array}{l}\text { Surfactant agents } \\
\text { Papermaking, } \\
\text { hydrophobization } \\
\text { of cellulose fibers } \\
\text { Hemostatic agent } \\
\text { Gene transfection } \\
\text { Paints } \\
\text { Oil recovery }\end{array}$ & $\begin{array}{l}\text { Macquarie and Hardy } \\
\text { (2005), Prabaharan and } \\
\text { Mano (2005), Mourya and } \\
\text { Inamdar (2008), Prabaharan } \\
\text { and Tiwari (2011), Canh } \\
\text { et al. (2004), Muñoz-Bonilla } \\
\text { et al. (2014), Verlee et al. } \\
\text { (2017), and Yu et al. (2018) }\end{array}$ \\
\hline \multicolumn{4}{|c|}{ N-methylene phosphonic chitosans } \\
\hline $\begin{array}{l}\text { Grafted with alkyl } \\
\text { chains } \\
\text { Bifunctional } \\
\text { derivatives }\end{array}$ & $\begin{array}{l}\text { Anionic products } \\
\text { with possible } \\
\text { amphoteric } \\
\text { character } \\
\text { Soluble products } \\
\text { Complexing } \\
\text { properties } \\
\text { Film-forming }\end{array}$ & $\begin{array}{l}\text { Chelating agent } \\
\text { Ability for metal } \\
\text { removal } \\
\text { Cosmetology } \\
\text { Anti-corrosion } \\
\text { protection }\end{array}$ & $\begin{array}{l}\text { Ramos et al. (2003), Canh } \\
\text { et al. (2004), Prabaharan and } \\
\text { Tiwari (2011), and Yu et al. } \\
\text { (2018) }\end{array}$ \\
\hline \multicolumn{4}{|c|}{ Target derivatives/reactions } \\
\hline $\begin{array}{l}\text { Schiff's base formation } \\
\text { Reductive amination } \\
\text { Amide formation } \\
\text { Michael addition } \\
\text { EDTA-chitosan } \\
\text { Thiolated chitosan } \\
\text { Thiourea derivatives } \\
\text { Phosphorylated chitosan } \\
\text { Azidated derivatives } \\
\text { Folate-based derivatives } \\
\text { Imidazole chitosan } \\
\text { Phthaloylated chitosan } \\
\text { Conjugated with lipids }\end{array}$ & \begin{tabular}{|l|} 
Highly porous \\
structure \\
High solubility over \\
a wide range of pH \\
pH-sensitive \\
High transfection \\
efficiency \\
High cellular \\
uptake \\
Mucoadhesive \\
materials
\end{tabular} & \begin{tabular}{|l||} 
Gene carrier \\
Anticancer agent \\
Drug delivery \\
Ocular drug \\
delivery \\
Delivery of contrast \\
agents \\
Metal chelation
\end{tabular} & $\begin{array}{l}\text { Canh et al. (2004), } \\
\text { Macquarie and Hardy } \\
\text { (2005), Prabaharan and } \\
\text { Mano (2005), Jayakumar } \\
\text { et al. (2006, 2008), Mourya } \\
\text { and Inamdar (2008), } \\
\text { Muñoz-Bonilla et al. (2014), } \\
\text { Ahmed and Ikram (2016), } \\
\text { Choi et al. (2016), Osman } \\
\text { and Arof (2017), and Yu } \\
\text { et al. (2018) }\end{array}$ \\
\hline
\end{tabular}


Table 2.6 (continued)

\begin{tabular}{|c|c|c|c|}
\hline $\begin{array}{l}\text { Some chitosan } \\
\text { derivatives }\end{array}$ & $\begin{array}{l}\text { Important } \\
\text { properties and } \\
\text { comment }\end{array}$ & Application & References \\
\hline \multicolumn{4}{|c|}{ Carbohydrate-branched chitosans } \\
\hline $\begin{array}{l}\text { Sugar derivatives } \\
\text { Glycol-based chitosan } \\
\text { Glucosamine chitosan } \\
\text { Galactosylated } \\
\text { chitosan } \\
\text { Mannose or lactose } \\
\text { derivatives } \\
\text { Cyclodextrin-linked } \\
\text { chitosan } \\
\text { Cyclic-host bound } \\
\text { chitosan }\end{array}$ & $\begin{array}{l}\text { Water-soluble } \\
\text { derivatives at wide } \\
\text { range of } \mathrm{pH} \\
\text { Ability to form } \\
\text { physical or } \\
\text { chemical gels } \\
\text { Faster } \\
\text { biodegradability } \\
\text { Enhanced } \\
\text { antimicrobial } \\
\text { properties }\end{array}$ & $\begin{array}{l}\text { Drug delivery } \\
\text { Self-assembled } \\
\text { systems } \\
\text { Bone healing } \\
\text { Coagulating/ } \\
\text { Flocculating agents } \\
\text { Adsorbents }\end{array}$ & $\begin{array}{l}\text { Sashiwa and Aiba (2004), } \\
\text { Jalal Zohuriaan-Mehr } \\
\text { (2005), Prabaharan and } \\
\text { Mano (2006), Alves and } \\
\text { Mano (2008), Mourya and } \\
\text { Inamdar (2008), Prabaharan } \\
\text { and Tiwari (2011), Wang } \\
\text { et al. (2012), and Muñoz- } \\
\text { Bonilla et al. (2014) }\end{array}$ \\
\hline \multicolumn{4}{|c|}{ Chitosan-grafted copolymers } \\
\hline 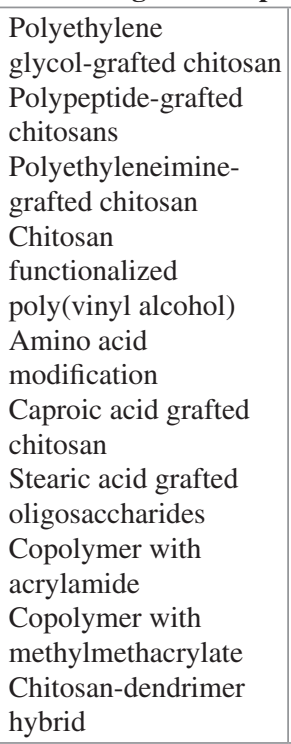 & $\begin{array}{l}\text { Water-soluble } \\
\text { derivatives } \\
\text { The solubility } \\
\text { depends on the } \\
\text { degree of grafting } \\
\text { Induced } \\
\text { hydrophilicity or } \\
\text { hydrophobicity } \\
\text { Biodegradability } \\
\text { and non-toxicity: } \\
\text { poly }(\gamma \text {-glutamic } \\
\text { acid)-chitosan } \\
\text { complexes } \\
\text { Enhance cell } \\
\text { penetrating } \\
\text { Improved } \\
\text { intracellular release } \\
\text { Thermos- } \\
\text { responsive gels }\end{array}$ & $\begin{array}{l}\text { Drug delivery } \\
\text { Self-assembled } \\
\text { systems } \\
\text { Oral delivery of } \\
\text { insulin } \\
\text { Protein vaccine } \\
\text { delivery } \\
\text { Gene carriers } \\
\text { Wastewater } \\
\text { treatment }\end{array}$ & $\begin{array}{l}\text { Canh et al. (2004), Sashiwa } \\
\text { and Aiba (2004), Harish } \\
\text { Prashanth and Tharanathan } \\
\text { (2007), Mourya and Inamdar } \\
\text { (2008), Wang et al. (2012), } \\
\text { Thakur and Thakur (2014), } \\
\text { Choi et al. (2016), Rafique } \\
\text { et al. (2016), Sahariah and } \\
\text { Másson (2017), Farion et al. } \\
\text { (2018), Rahangdale and } \\
\text { Kumar (2018), and Yu et al. } \\
\text { (2018) }\end{array}$ \\
\hline
\end{tabular}


Table 2.6 (continued)

\begin{tabular}{|c|c|c|c|}
\hline $\begin{array}{l}\text { Some chitosan } \\
\text { derivatives }\end{array}$ & $\begin{array}{l}\text { Important } \\
\text { properties and } \\
\text { comment }\end{array}$ & Application & References \\
\hline \multicolumn{4}{|l|}{ Cross-linked chitosans } \\
\hline $\begin{array}{l}\text { Gels/Hydrogels } \\
\text { Glutaraldehyde } \\
\text { chitosan } \\
\text { Self-assembled } \\
\text { systems } \\
\text { Ionic modification } \\
\text { Tripolyphosphate as } \\
\text { cross-linker } \\
\text { Genipin-cross-linked } \\
\text { products } \\
\text { Modification by } \\
\text { aldehydes } \\
\text { Glycosaminoglycan- } \\
\text { based systems }\end{array}$ & $\begin{array}{l}\text { Biocompatible and } \\
\text { cationic products } \\
\text { Thermosensitive } \\
\text { properties } \\
\text { pH-dependent } \\
\text { Biosorbents } \\
\text { Scaffolds } \\
\text { Injectable } \\
\text { hydrogels }\end{array}$ & $\begin{array}{l}\text { Wastewater } \\
\text { treatment } \\
\text { Enzyme } \\
\text { immobilization } \\
\text { Drug delivery } \\
\text { Tissue engineering } \\
\text { Veterinary } \\
\text { applications } \\
\text { Drug eluting stents }\end{array}$ & $\begin{array}{l}\text { Crini (2005), Crini and } \\
\text { Badot (2008), Dash et al. } \\
\text { (2011), Luna-Bárcenas et al. } \\
\text { (2011), Van Vlierberghe } \\
\text { et al. (2011), Yao et al. } \\
\text { (2012), Xiao et al. (2012), } \\
\text { Zhao (2012), Croisier and } \\
\text { Jérôme (2013), Zambito } \\
\text { (2013), Ahmadi et al. (2015), } \\
\text { Tonda-Turo et al. (2016), } \\
\text { Ahmed and Ikram (2017), } \\
\text { Aminabhavi and } \\
\text { Dharupaneedi (2017), and } \\
\text { Ali and Ahmed (2018) }\end{array}$ \\
\hline \multicolumn{4}{|c|}{ Composites/Miscellaneous } \\
\hline $\begin{array}{l}\text { Chitosan complexes } \\
\text { Metal ion chelates } \\
\text { Chitosan/gelatin } \\
\text { microspheres } \\
\text { Glycol chitosan } \\
\text { Cyanoethyl chitosan } \\
\text { Linoleic acid chitosan } \\
\text { complex } \\
\text { Imidazole chitosan } \\
\text { Chitosan-coated } \\
\text { materials } \\
\text { Hyaluronic acid- } \\
\text { chitosan nanoparticles } \\
\text { Alginate-chitosan } \\
\text { systems } \\
\text { Blending with starch } \\
\text { Calcium phosphate- } \\
\text { based systems } \\
\text { Hydroxypropyl- } \\
\text { chitosan/gelatin } \\
\text { systems } \\
\text { Cellulose-chitosan } \\
\text { blends } \\
\text { Hydroxyapatite } \\
\text { composites } \\
\text { Modified ceramic } \\
\text { nanoparticles } \\
\text { Chitosan and clays }\end{array}$ & $\begin{array}{l}\text { Microcapsules } \\
\text { Bioactive } \\
\text { nanoparticles } \\
\text { Nanoemulsions } \\
\text { Membranes } \\
\text { Delivery vehicles } \\
\text { Hybrid scaffolds, } \\
\text { multifunctional } \\
\text { scaffolds } \\
\text { Nanofibers } \\
\text { Biosensors }\end{array}$ & $\begin{array}{l}\text { Insulating papers } \\
\text { and special papers } \\
\text { Dialysis } \\
\text { Drug delivery } \\
\text { Wound dressing } \\
\text { Bone repair } \\
\text { Bone tissue } \\
\text { engineering } \\
\text { Surgical dressing } \\
\text { Gene transfection } \\
\text { ability } \\
\text { Gene therapy } \\
\text { Anticancer agent } \\
\text { Glucose sensor } \\
\text { Antimicrobial } \\
\text { textiles } \\
\text { Veterinary vaccines } \\
\text { Bioimaging agents } \\
\text { Wastewater } \\
\text { treatment }\end{array}$ & $\begin{array}{l}\text { Mourya and Inamdar (2008), } \\
\text { Van Vlierberghe et al. } \\
\text { (2011), Dash et al. (2011), } \\
\text { Gerdts et al. (2013), Elsabee } \\
\text { and Abdou (2013), Islam } \\
\text { et al. (2013), Muñoz-Bonilla } \\
\text { et al. (2014), van den Broek } \\
\text { et al. (2015), Abdul Khalil } \\
\text { et al. (2016), Ahmed and } \\
\text { Ikram (2016), and Elieh-Ali- } \\
\text { Komi and Hamblin (2016) }\end{array}$ \\
\hline
\end{tabular}




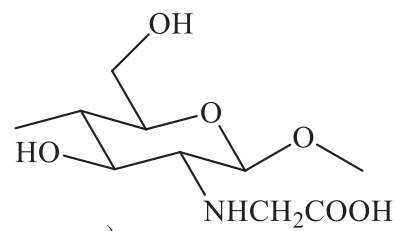

a)

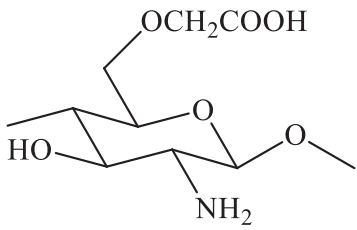

c)

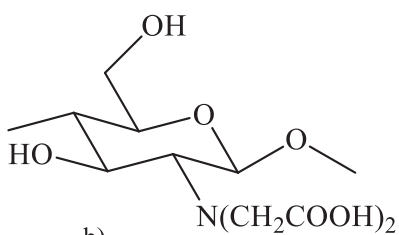

b)

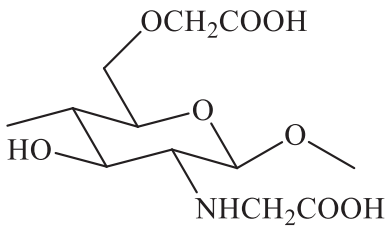

d)

Fig. 2.8 Different chemical structures of carboxymethyl chitosans: (a) N-carboxymethyl chitosan; (b) N,N-carboxymethyl chitosan; (c) O-carboxymethyl chitosan; and (d) N,O-carboxymethyl chitosan

et al. 2018). The biotechnological processes have also been gained interest because they permit the production of high-value commercial by-products such as chitinases, lactic acid, antioxidants, valuable protein hydrolysates, carotenoids, and solubilized calcium ions (Philibert et al. 2017).

\subsection{Chitosan Applications}

Currently, chitosan and its derivatives have practical applications in the form of solutions, suspensions, particles, e.g. beads, resins, spheres, nanoparticles and sponges, gels/hydrogels, foams, membranes and films, fibers, microscopic threads, and scaffolds in many fields: medicine and biomedicine, pharmacy, cosmetology, hygiene and personal care, food industry and nutrition, agriculture and agrochemistry, textile and paper industries, edible film industry and packaging, biotechnology, chemistry, and catalysis, chromatography, beverage industry and enology, photography and other emerging fields such as nutraceuticals, functional textiles and cosmeto-textiles, cosmeceuticals, nanotechnology, and aquaculture (Sandford 1989; Onsoyen and Skaugrud 1990; No and Meyers 1995; Li et al. 1997; Ravi Kumar 2000; Khor 2001; Struszczyk 2002; Honarkar and Barikani 2009; Crini et al. 2009; Ferguson and O'Neill 2011; Kardas et al. 2012; Khor and Wan 2014; Hamed et al. 2016; Amber Jennings and Bumgardner 2017a; Arfin 2017; Badawy and Rabea 2017; Dima et al. 2017; Philibert et al. 2017). Chitosan as biopolymer is also proposed for environmental purposes and applied in clarification and water 
purification, wastewater treatment, remediation, sludge dewatering and membrane filtration (Crini and Badot 2008; Bhatnagar and Sillanpää 2009; Sudha 2011; Ravichandran and Rajesh 2013; Yong et al. 2015; Barbusinski et al. 2016; Kos 2016; Nechita 2017; Desbrières and Guibal 2018; Pakdel and Peighambardoust 2018).

Research on chitosan is also very active in electrochemical sensors, bio-imaging, bio-catalysis, ionic liquids, green solvents, adhesives, and detergents. However, the main markets are the food industry and nutrition, and the pharmaceutical, cosmetic, and medicine industries. It is interesting to note that the vast majority of these biological and chemical applications are based on the cationic nature of chitosan and on its versatility as biomaterial. The markets for chitin and chitosan are Japan, USA, Korea, China, Canada, Norway, Australia, France, UK, Poland, and Germany (Ferraro et al. 2010; Nwe et al. 2011b; Badawy and Rabea 2017; Bonecco et al. 2017). Japan dominated the industry accounting for $35 \%$ of the market in 2015 . Indeed, since the 1980s, Japan is considerably advanced in the technology, commercialization and use of these biopolymers (Badawy and Rabea 2017; Bonecco et al. 2017). The market in this country absorbs about 700-800 tons chitosan per year.

\subsubsection{Food Industry}

Table 2.7 describes applications of chitosan and its oligosaccharides in food industry. Chitosan has been approved by the US Food and Drug Administration as a generally recognized as sage food additive, dietary fibre (hypocholesterolemic effect), and functional ingredients for the consumer. Chitosan is also approved as a food additive in Japan and in Korea since the 1990s (Vidanarachchi et al. 2011; Gutiérrez 2017). Due to its bioactive nature and cationic character, chitosan is used as nutritional ingredient (food additives, functional food), antimicrobial and antioxidant agent (food protection), for antimicrobial coatings for fruits and vegetables, in anticholesterolemic dietary products, and as nutraceuticals (Shahidi et al. 1999; Agulló et al. 2003; Synowiecki and Al-Khateeb 2003; Vidanarachchi et al. 2011; Kardas et al. 2012; Je and Kim 2012, 2013; van den Broek et al. 2015; Gutiérrez 2017; Han et al. 2018).

Friedman and Juneja (2010) pointed out the outstanding antimicrobial activities of chitosan in solution, powders, and edible films and coating against microorganisms. The better results were obtained with low molecular weight chitosan. Actually, research is directed to new chitosan derivatives and oligomers that can be applied as antimicrobial agent against food microorganisms. These derivatives seem promising, in particular for nutraceutical applications. Kardas et al. (2012) demonstrated that chitosan and its derivatives offer a wide range of unique applications in the food industry including preservation of foods from microbial deterioration, shelf-life extension, formation of biodegradable films and food packaging. The products used as a packaging or coating material can be formed into fibers, films, gels, beads, or nanoparticles. Van den Broek et al. (2015), reviewing the development of chitosan 
Table 2.7 Applications of chitosan and its oligosaccharides in food industry (selected reviews)

\begin{tabular}{|c|c|c|}
\hline Topic & Form & Applications \\
\hline $\begin{array}{l}\text { Food technology } \\
\text { Nutrition } \\
\text { Functional foods } \\
\text { Food additives } \\
\text { Food mimetic } \\
\text { Food protection } \\
\text { Food preservation } \\
\text { Seafood quality } \\
\text { preservation } \\
\text { Industrial bio-products } \\
\text { Nutraceutical ingredients } \\
\text { Dietary food additives } \\
\text { Dietary fiber } \\
\text { Prebiotic ingredient } \\
\text { Flavors/Aromas } \\
\text { Essential oils } \\
\text { Feed additives } \\
\text { Immobilization of } \\
\text { enzymes } \\
\text { Edible film industry } \\
\text { Packaging } \\
\text { Coating material } \\
\text { Food processing wastes } \\
\text { Removal of substances }\end{array}$ & $\begin{array}{l}\text { Solution } \\
\text { Film } \\
\text { Blend } \\
\text { Coating } \\
\text { Bead }\end{array}$ & $\begin{array}{l}\text { Additives: fining agent, texture controlling agent, natural } \\
\text { flavor extender, emulsifying agent, gelling agent, color } \\
\text { stabilizer, dye-binding properties, thickener and stabilizer } \\
\text { for sauces, flavor extender } \\
\text { Improve nutritional quality } \\
\text { Bioactivities: antibacterial, antifungal, antioxidants } \\
\text { Preservation of foods from microbial deterioration: } \\
\text { protective for fruits } \\
\text { Filmogenic properties; microbial films (bactericidal, } \\
\text { fungicidal); food wrapping } \\
\text { Edible films: controlled release of antioxidants, flavors or } \\
\text { nutrients; antimicrobial substances controlled release; } \\
\text { reduction of oxygen partial pressure; moisture transfer } \\
\text { control; temperature control; controlled rate of respiration } \\
\text { Diet foods and dietary fibers: not digestible by humans; } \\
\text { glucose dialysis; water holding capacity } \\
\text { Hypolipidemic and hypocholesterolemic activities: } \\
\text { reduction of lipid absorption, bind fats/lipids, reduce } \\
\text { cholesterol } \\
\text { Astringency: able to precipitate saliva proteins } \\
\text { Non-digestible feed ingredients: prebiotics } \\
\text { Production of single cell protein } \\
\text { Enhancement of the calcium absorption } \\
\text { Encapsulation of nutraceuticals } \\
\text { Fractionation of agar } \\
\text { Biotechnology: immobilization matrix } \\
\text { Bioconversion for the production of value-added food } \\
\text { products } \\
\text { Recovery of waste material from food-processing discards } \\
\text { Infant feed ingredient } \\
\text { Animal feed additive } \\
\text { Undesired substances removal: dyes, suspended solids } \\
\text { Water purification }\end{array}$ \\
\hline
\end{tabular}

\section{References}

Goosen (1997), Muzzarelli and de Vincenzi (1997), Shahidi et al. (1999), Domard and Domard (2001), Struszczyk (2002), Agulló et al. (2003), Peniche et al. (2003), Roller and Valley (2003), Begin et al. (2004), Cagri et al. (2004), Shahidi (2004), Krajewska (2005), No et al. (2007), Fernandez-Saiz et al. (2010), Rodrigues et al. (2012), Je and Kim (2012, 2013), Alishahi (2012), Coma (2012), Elsabee and Abdou (2013), Muñoz-Bonilla et al. (2014), van den Broek et al. (2015), Zivanovic et al. (2015), Gallo et al. (2016), Hamed et al. (2016), Gutiérrez (2017), Han et al. (2018), Perinelli et al. (2018), and Wang et al. (2018)

films and blends as packaging material, also reported a similar conclusion. Due to its antimicrobial and film-forming activities, chitosan has been considered as an appropriate alternative as source of food preservative or coating material for replacing the non-biodegradable and non-renewable polymers, and also reducing the extensive application of harmful pesticides in food protection. Indeed, its films have a selective permeability to gasses (Friedman and Juneja 2010; Fernandez-Saiz et al. 
2010; Kardas et al. 2012; Elsabee and Abdou 2013; Muñoz-Bonilla et al. 2014; van den Broek et al. 2015). In addition, the chitosan films have shown superior results, good mechanical properties and they have the advantage of being able to incorporate functional substances such as vitamins and as carriers releasing of antimicrobial agents. However, chitosan films in packaging application are highly permeable to water vapor, and due to their hydrophilic character, they also tend to exhibit resistance to fat diffusion and selective gas permeability. A discussion on the different strategies to overcome these drawbacks can be found in the reviews by Kardas et al. (2012), Elsabee and Abdou (2013), van den Broek et al. (2015), and Wang et al. (2018). Blends, composites and multilayer systems containing chitosan have been proposed as films in food packaging fields and seem promising.

The field of food industry and nutrition is the most important user of chitosan (Gutiérrez 2017; Philibert et al. 2017) and the main markets are localized in Asia (Japan, Korea, China), North America, and in Europe. In the USA, the market in food and beverages is estimated to be 2288 metric tons in 2018. The demand for chitosan is growing rapidly, in particular for potential applications in nutraceutical ingredients and feed stocks. Nutraceuticals as an industry emerged in the early 1990's in Asia, in particular in Japan. The nutraceutical industry includes functional foods, dietary supplements and herbal/natural products. Actually, the US market represents the largest nutraceutical market in the world and the Europe (Germany, France, Netherlands, Sweden) the second. China is expected to be the world's largest consumer of nutraceuticals by 2030. Many products available (ChitoClear ${ }^{\circledR}$, Chitoseen ${ }^{\mathrm{TM}}-\mathrm{F}$, MicroChitosan NutriCology ${ }^{\circledR}$, etc.) are marketed as fat reducers and cholesterol-lowering agents, and also as antioxidant agents. For instance, ChitoClear ${ }^{\circledR}$ is noted as a natural, safe and effective weight loss supplement when used in conjunction with a healthy life style (PRIMEX, Iceland). It seems to have a potential in weight management and obesity treatment. However, there is a debate surrounding the effectiveness of chitosan at blocking fat absorption. The nutraceutical properties of chitosan include its antibacterial, anti-inflammatory, antioxidant, anti-carcinogenic, and antiulcer bioactivities, along with its application as a dietary fiber. Chitosan has non-digestibility in the upper gastrointestinal tract, high viscosity, and high water binding properties (Muzzarelli and de Vincenzi 1997; Roller and Valley 2003; Badawy and Rabea 2017). As a dietary fiber, it has ability to lower cholesterol by blocking the absorption of dietary fat and cholesterols. Chitosan and its derivatives have been shown to facilitate weight and body fat loss in the human body thus decreased systolic and diastolic blood pressure (Philibert et al. 2017). Additionally, it significantly increases the excretion of highly atherogenic saturated fatty acids compared with other fibers. As a valuable prebiotic, chitosan can also promote colonic conditions. Gutiérrez (2017) recently reported that chitosan and its derivatives also exert strong antioxidant activity and their effects are similar to those of phenolic antioxidants. Chitosan products also offer benefits as components of animal feeds and this is also a growing market. They permit food processors to recycle protein from biowastes into animal feed. They have beneficial nutritional properties and they can control the release of feed additives in animals. 


\subsubsection{Beverage Industry}

Table 2.8 summarizes the potential uses of chitosan in beverage industry. In wine production, it can be used for clarification, de-acidification, stabilization, elimination of ochratoxin A, enzymes and other undesired substances, e.g. metals and pesticides (Bornet and Teissedre 2011). Chitosan is also used as eco-friendly coagulant for passion fruit clarification (Domingues et al. 2012) and natural flocculant for beer clarification (Gassara et al. 2015). Recently, Rocha et al. (2017) presented an overview of the recent chitosan-based matrices used for clarification, preservation, encapsulation, and active and intelligent packaging of different beverage types, such as alcoholic, dairy-based drinks, and non-alcoholic, including fruit juices, nectars, concentrated fruit juices, tea, coffee, and tisanes. Only the clarification using chitosan of fungal origin (Oneobrett ${ }^{\circledR}$, Bactiless ${ }^{\mathrm{TM}}$ ) seems to be well implemented in the market.

Table 2.8 Applications of chitosan and its derivatives and oligosaccharides in beverage industry

\begin{tabular}{|c|c|c|}
\hline Topic & Form & Applications \\
\hline $\begin{array}{l}\text { Beverages } \\
\text { Functional } \\
\text { beverages } \\
\text { Enology } \\
\text { Beer industry } \\
\text { Packaging }\end{array}$ & $\begin{array}{l}\text { Solution } \\
\text { Particle } \\
\text { Bead }\end{array}$ & $\begin{array}{l}\text { Filtration and clarification of fruit juices and beverages (wines, } \\
\text { beer, tea) } \\
\text { Natural flocculant: turbidity removal, removal of suspended } \\
\text { solids and colloids (polyphenols, proteins, polysaccharides, } \\
\text { minerals) } \\
\text { Acidity-adjusting agent: de-acidification of fruit juices and } \\
\text { beverages } \\
\text { Stabilization of beverages (white wines) } \\
\text { Preservative in fruit juices, wines and milk } \\
\text { Color stabilizer } \\
\text { Prevention of oxidation of the wine color } \\
\text { Antimicrobial agent: preservation of drinks from microbial } \\
\text { deterioration (bacteria, yeasts, moulds) } \\
\text { Natural flavor extender } \\
\text { Bioactive compounds encapsulation: protection to oxidation, to } \\
\text { improve the bioavaibility of probiotics, making of undesirable } \\
\text { taste } \\
\text { Preservatives and active packaging } \\
\text { Complexing agents in wine industry: metal removal } \\
\text { Removal of dead yeast, excess tannin, particulates } \\
\text { Water purification }\end{array}$ \\
\hline
\end{tabular}

\section{References}

Shahidi et al. (1999), Struszczyk (2002), Chatterjee et al. (2004), Bornet and Teissedre (2005, 2011), Rungsardthong et al. (2006), Domingues et al. (2012), Gassara et al. (2015), Tastan and Baysal (2015), and Rocha et al. (2017) 


\subsubsection{Pharmacy}

For chitosan, pharmaceutical applications started to appear in the late 1980s (Nagai et al. 1984; Felt et al. 1998; Ravi Kumar 2000). In this field, chitosan and its derivatives have been mainly explored as excipients in drug formulations and in drug delivery systems (Badwan et al. 2015). The new approach consisted of replacing potentially toxic compounds by natural products, which rapidly proved to be promising. The pharmaceutical industry rapidly understood the advantages of using chitosan. Although hundreds of papers and patents related to chitosan-based pharmacy have been published since the late 1980s, this sector continues to interest both the scientific community and the industry, mainly in terms of bioactivities. The most important features and advantages of chitosan can be found in the review by Bernkop-Schnürch and Dünnhaupt (2012). Its derivatization also contributed to expansion of application and decrease toxicity.

The main properties used in the pharmaceutical field are: controlled drug release, e.g. anti-inflammatory naproxen, mucoadhesive properties, in situ gelling properties, transfection enhancing properties (deoxyribonucleic acid- and small interfering ribonucleic acid ribonucleic acid-based drugs form stable complexes with chitosan), and permeation enhancing properties (Bernkop-Schnürch and Dünnhaupt 2012). Chitosan also exhibits efflux pump inhibitory properties like other polysaccharides. Chitosan and its derivatives may be used as solutions, gels, tablets, capsules, fibers, films and sponges (Ali and Ahmed 2018). Consequently, they may be used in oral, ocular, nasal, vaginal, buccal, parenteral, intravesical, and transdermal administration, and as implants for drug delivery in both implantable and injectable forms. Table 2.9 reports different methods for the preparation of chitosan-based drug delivery systems (Felt et al. 1998; Ravi Kumar 2000; Peniche et al. 2003; Ravi Kumar et al. 2004; Dash et al. 2011; Ali and Ahmed 2018). Akbar and Shakeel (2018) recently discussed the various forms of chitosan materials as drug delivery device and attempted to report the vast literature available on chitosan based systems in drug delivery applications. Hamedi et al. (2018) also summarized the potential applications of chitosan-based hydrogels for pharmaceutical and biomedical uses, particularly with regard to drug delivery in wound dressings.

Drug delivery applications include not only controlled drug release systems, e.g. site-specific antibiotics delivery in the stomach and controlled release of proteins, but also vaccine and gene delivery (Singh et al. 2018). Chitosan is used as safe excipients in oral dosage form over the last two decades (Felt et al. 1998; Ravi Kumar 2000; Ravi Kumar et al. 2004). Chitosan tablet can exhibit a sustained drug release compared to commercial products. Bernkop-Schnürch and Dünnhaupt (2012) reported that tablets are the likely most favorable dosage form since they provide an accurate dosage, are easy to manufacture and handle, and are favored by patients. The buccal route is an alternative choice to deliver drugs. Chitosan is interesting to be used for buccal delivery due to its mucoadhesive bioactivity and absorption enhancement property. Strong permeation enhancing properties are also mentioned. 
Table 2.9 Chitosan-based drug delivery systems prepared by different methods

\begin{tabular}{l|l|l}
\hline Form & Applications & Drug(s) \\
\hline Microspheres & $\begin{array}{l}\text { Water-in-oil emulsion cross-linking } \\
\text { Coacervation/precipitation } \\
\text { Spray-drying } \\
\text { Ionic gelation } \\
\text { Sieving method }\end{array}$ & $\begin{array}{l}\text { Diclofenac, aspirin, } \\
\text { 5-fluorouracil }\end{array}$ \\
\hline Beads & Coacervation/precipitation & $\begin{array}{l}\text { Bovine serum albumin, } \\
\text { salbutamol }\end{array}$ \\
\hline Nanoparticles & $\begin{array}{l}\text { Emulsion-droplet coalescence } \\
\text { Coacervation/precipitation } \\
\text { Ionic gelation } \\
\text { Reverse micellar method }\end{array}$ & Insulin, cyclosporin A \\
\hline Gels/Hydrogels & Cross-linking reactions & Caffeine, lidocaine \\
\hline Tablets & Matrix coating & Diclofenac, salicylic acid \\
\hline Capsules/Microcapsules & Capsule shell & Insulin \\
\hline Films & Wet casting from salt solutions & Testosterone, trypsin \\
\hline Sponges/Foams & $\begin{array}{l}\text { Freeze drying } \\
\text { Reactions in supercritical fluids }\end{array}$ & Triamcinolone acetonide \\
\hline
\end{tabular}

Injectable preparations containing chitosan have received considerable attention within the last years. The properties of chitosan also resulted in the development of vaccine delivery (Bernkop-Schnürch and Dünnhaupt 2012). The transmucosal administration of drugs has been described in detail by Illum and Davis (2004). The transmucosal absorption promoter effect of chitosan is important for nasal and oral delivery of polar drugs to administrate peptides and proteins, and for vaccine delivery. Films and fibers prepared using chitosan and chitin were developed for tissue engineering and wound care dressing, as oral mucoadhesive and water-resisting adhesive by virtue of their release characteristics and adhesion (Kato et al. 2003; Illum and Davis 2004). The chitosan-based fiber production was discussed in detail by Pillai et al. (2009). Promising developments were under way not only in biomedicine but also in emerging domains such as nutraceuticals and cosmeceuticals. Indeed, pharmaceutical formulations containing chitosan and derivatives are also proposed for slimming application, body weight management and as cosmetics to enhance skincare efficacy for example. The use of nanocomposites in drug delivery also seems promising as recently reported by Ali and Ahmed (2018). Other applications of chitosan and its derivatives are described in Table 2.10.

\subsubsection{Medicine}

The medical and biomedical potential applications of chitosan include pharmaceutical formulation and drug delivery (antibiotics, anti-inflammatory substances, vaccines, proteins, peptides, growth of factors), antimicrobial applications, gene delivery, gene therapy, wounds healing and burns, regenerative medicine, tissue 
Table 2.10 Applications of chitosan and its derivatives including oligosaccharides in pharmacy (selected reviews)

\begin{tabular}{l|l|l}
\hline Topic & Form & Applications \\
\hline Excipients & Solution & Excipients \\
Drug delivery & Powder & Encapsulation of sensitive drugs: to \\
Drug release & Microsphere & increase and to modulate drug release \\
Vaccines & Bead & rate \\
Biopharmaceutics & Tablet & Controlled drug delivery carriers \\
Nutraceuticals & Capsule, microcapsule & Controlled release of proteins and \\
Body weight management & Nanoparticle & peptides \\
Cosmeceuticals & Nanocomposite & Gene delivery (nucleic acid) \\
Dermatology & Sponge & Dermatological products: to treat acne \\
Ophthalmology & & Hydrating agent \\
Oral drug delivery & & Hemostatic and anticoagulant \\
Imaging agents & Bacteriostatic agent \\
& & Mucoadhesion \\
& & Biological adhesive: water-resisting \\
& & adhesive \\
& & In situ gelation \\
& & Transfection \\
& & Permeation enhancement \\
& & Healing: wound healing, self-healing \\
& & Efflux pump inhibitory properties \\
& & Products for radio-pharmaceutical \\
domains \\
Nutraceutical ingredients
\end{tabular}

\section{References}

Goosen (1997), Illum (1998), Dodane and Vilivalam (1998), Felt et al. (1998), Ravi Kumar (2000), Hejazi and Amiji (2001), Agnihotri et al. (2004), Canh et al. (2004), Ravi Kumar et al. (2004), Prabaharan and Mano (2005), Varshosaz (2007), Dash et al. (2009), Kang et al. (2009), Hamman (2010), Riva et al. (2011), Bernkop-Schnürch and Dünnhaupt (2012), Xiao et al. (2012), Zhao (2012), Yong and Wong (2013), Badwan et al. (2015), Mateescu et al. (2015b), Majekodunmi (2016), Lucio and Martínez-Ohárriz (2017), Parhi (2017), Ahsan et al. (2018), Akbar and Shakeel (2018), Ali and Ahmed (2018), Krishnaswami et al. (2018), Naskar et al. (2018), and Tripathi and Singh (2018)

engineering (bone, ligament, cartilage, tendon, liver, neural and skin regeneration), applications in cancer (treatment, therapy, diagnostic strategy), dermatology, ophthalmology, dentistry, biosensors, and many other applications such as bio-imaging (magnetic resonance imaging), support for immobilized enzymes and veterinary medicine (Table 2.11). For medical applications, chitosan and its derivatives as chitooligosaccharides can be easily processed into different forms such as solutions, gels/hydrogels, sponges, microparticles/nanoparticles, membranes and films (pure films or blends, adhesives), and fibers/nanofibers (Allan et al. 1984; Hon 1996; Dumitriu 2001; Yilmaz 2004; Jayakumar et al. 2010b, 2011b; Riva et al. 2011; Elieh-Ali-Komi and Hamblin 2016; Amber Jennings and Bumgardner 2017a, b; Rijal et al. 2017; Ali and Ahmed 2018; Hamedi et al. 2018; Liaqat and Eltem 2018). The use of chitosan-based materials in 2D-scaffolds such as films and fibers and 3D-scaffolds such as gels and sponges is discussed in the reviews by Croisier and 
Table 2.11 Applications of chitosan and its oligosaccharides in medicine and biomedicine (selected reviews)

\begin{tabular}{|c|c|c|}
\hline Topic & Forms & Applications \\
\hline $\begin{array}{l}\text { Drug delivery } \\
\text { Biomedicine } \\
\text { Biomedical engineering } \\
\text { Biofabrication } \\
\text { Tissue engineering } \\
\text { Regenerative medicine } \\
\text { Wound dressing } \\
\text { Growth factor } \\
\text { Biomedical adhesives } \\
\text { Medical materials } \\
\text { Medical devices } \\
\text { Implants } \\
\text { Orthopedics } \\
\text { Therapeutic domains } \\
\text { Microbiology } \\
\text { Immunization } \\
\text { Immunology } \\
\text { Gene therapy } \\
\text { Cell biology } \\
\text { Cell therapy } \\
\text { Cell adhesion and } \\
\text { proliferation } \\
\text { Cell-biomaterials } \\
\text { interactions } \\
\text { Protein adsorption onto } \\
\text { biomaterials } \\
\text { Cancer diagnosis } \\
\text { Cancer therapy } \\
\text { Carriers of anticancer } \\
\text { drugs } \\
\text { Ophthalmology } \\
\text { Bio-sensing } \\
\text { Bio-imaging } \\
\text { Bio-printing } \\
\text { 3D-printing }\end{array}$ & \begin{tabular}{|l|} 
Solution \\
Gel/hydrogel \\
Powder \\
Microsphere \\
Microcapsule \\
Bead \\
Nanoparticle \\
Film \\
Fiber, nanofiber \\
Nonwoven bioactive \\
fiber \\
Sponge \\
2D- and \\
3D-scaffolds \\
Shaped object \\
Adhesive
\end{tabular} & $\begin{array}{l}\text { Drug delivery: delivery of antibiotics, } \\
\text { peptides, proteins, vaccines } \\
\text { Growth factor delivery } \\
\text { Biological response modifier } \\
\text { Gene delivery, targeted delivery, } \\
\text { deoxyribonucleic acids therapy, gene } \\
\text { therapeutics, small interfering ribonucleic acid } \\
\text { delivery } \\
\text { Antifungal, antimicrobial, anti-infectious } \\
\text { Hemostatic effects; enhances blood } \\
\text { coagulation } \\
\text { Anticoagulant hydrogel containing heparin } \\
\text { Blood cholesterol control } \\
\text { Adjuvant properties } \\
\text { Bioadhesive } \\
\text { Artificial skin; skin burn } \\
\text { Promotes tissue growth; tissue repair and } \\
\text { regeneration } \\
\text { Cartilage tissue engineering } \\
\text { Scaffolds for cell culture; stimulates cell } \\
\text { proliferation } \\
\text { Material supporting nerve repair } \\
\text { Wound healing properties } \\
\text { Scaffolds for bone regeneration: bone } \\
\text { substitutes and cements; rebuilding of bone } \\
\text { Biocompatible and biodegradable materials } \\
\text { for use as implants, blood substitutes, blood } \\
\text { vessels or wound dressing material } \\
\text { Antitumor agent, tumor inhibition } \\
\text { Treatment of leukemia, diabetes } \\
\text { Sutures, surgical threads, bandages, sponges } \\
\text { Dental implants } \\
\text { Contact lenses } \\
\text { Magnetic resonance imaging }\end{array}$ \\
\hline
\end{tabular}


Table 2.11 (continued)

\begin{tabular}{l|l|l}
\hline Topic & Forms & Applications \\
\hline Francis Suh and Matthew (2000), Khor and Lim (2003), Elder et al. (2004), Berger et al. \\
(2004a, b), Illum and Davis (2004), Sashiwa and Aiba (2004), Barbosa et al. (2005), Yi et al. \\
(2005), Shi et al. (2006), Jayakumar et al. (2007), Lee (2007), Alves and Mano (2008), Kang \\
et al. (2009), Muzzarelli (2009, 2011), Venkatesan and Kim (2010), Khor (2011), Sahoo and \\
Nayak (2011), Dash et al. (2011), Dutta et al. (2011), Jayakumar et al. (2011a), Lakshmanan \\
et al. (2011), Liu et al. (2011), Luna-Bárcenas et al. (2011), Sarmento and das Neves (2012), \\
Wang et al. (2012), Croisier and Jérôme (2013), Kim and Pangestuti (2013), Anitha et al. \\
(2014), Jana et al. (2014), Junginer and Sadeghi (2014), Muñoz-Bonilla et al. (2014), Balan and \\
Verestiuc (2014), Azuma et al. (2015), Pokhrel et al. (2015), Dutta (2016), Ahmed and Ikram \\
(2016), Elieh-Ali-Komi and Hamblin (2016), Choi et al. (2016), LogithKumar et al. (2016), \\
Ahmad et al. (2017a, b), Amber Jennings and Bumgardner (2017b), Balagangadharan et al. \\
(2017), Bano et al. (2017), Ellis and Korbutt (2017), Harris et al. (2017), Layek and Singh \\
(2017), Vunain et al. (2017), Aljohani et al. (2018), Ahsan et al. (2018), Ahmed et al. (2018), \\
Ahsan et al. (2018), Ali and Ahmed (2018), Anraku et al. (2018), Baranwal et al. (2018), De \\
Mori et al. (2018), Dimassi et al. (2018), Ding et al. (2018), Hamedi et al. (2018), Hu et al. \\
(2018), Li et al. (2018), Komi et al. (2018), Krishnaswami et al. (2018), Liaqat and Eltem \\
(2018), Mohandas et al. (2018), Nezakati et al. (2018), Oryan et al. (2018), Pellá et al. (2018), \\
Qasim et al. (2018), Shariatinia and Jalali (2018), Singh et al. (2018), Tripathi and Singh \\
(2018), Xing et al. (2018), Vasconcelos and Pomin (2018), Xu et al. (2018), and Zhao et al. \\
(2018)
\end{tabular}

Jérôme (2013), Anitha et al. (2014), Ahmed and Ikram (2016), and LogithKumar et al. (2016), with a special focus on tissue engineering and wound healing applications. Their bacteriostatic and fungistatic properties are particularly useful for wound treatment. This application combines two of the most interesting properties of chitosan: antimicrobial activity and biocompatibility. Chitosan and its oligosaccharides have also a stimulatory effect on cells. Materials in the forms of nonwovens, nanofibers, composites, films and sponges can accelerate wound healing and dermal regeneration. These products have been on the market since the early 1990s, mainly in North America and Asia, and more recently in Europe (Germany, France). Actually, the main biomedical commercial applications of chitosan are in wound healing.

Various forms of wound dressing chitosan-based materials are commercially available in the market: HemCon ${ }^{\circledR}$ Bandage, ChitoGauze ${ }^{\circledR}$ PRO, ChitoFlex ${ }^{\circledR}$ PRO, ChitoSam $^{\mathrm{TM}}$,Syvek-Patch ${ }^{\circledR}$, Chitopack $\mathrm{C} \AA$ and Chitopack $\mathrm{S} \AA$, Chitodine ${ }^{\circledR}$, ChitosanSkin ${ }^{\circledR}$, TraumaStat ${ }^{\circledR}, \operatorname{TraumaDEX}{ }^{\circledR}, \operatorname{Celox}^{\mathrm{TM}}$, etc. For example, HemCon ${ }^{\circledR}$ Bandage is an engineered chitosan acetate preparation designed as a high-performance hemostatic dressing (HemCon Medical Technologies, Inc., USA). Other biomedical products are in the market. Reaxon $®$ (Medovent, Germany) is a chitosan-based nerve conduit which is resistant to collapse and helps to avoid the undesired drawbacks of autografts. This hydrogel is bioactive (supports nerve regeneration equivalent to the autograft), biocompatible (prevents irritation and inflammation), antiadhesive (inhibits scar tissue and neuroma formation), and antibacterial (prevents infection). Its particular structure also facilitates the transport of 
nutrients and oxygen. ChitoSeat ${ }^{\mathrm{TM}}$ is a family of chitosan based hemostatic sealants that are suitable for surgical hemorrhage of hard and soft tissue (LUNA, USA).

In tissue engineering, the aim is to restore or replace damaged body parts or lost organs by transplanting supportive scaffolds with appropriate cells that in combination with biomolecules generate new tissue (Dash et al. 2011; Saravanan et al. 2013; Ahmed et al. 2018). Dash et al. (2011) reported that chitosan is an ideal dressing in wound-healing applications due to the fact that not only it protects the wound from bacterial infection but also it promotes healing and it produces less scarring. In addition to the reparative nature of the material, it can also deliver a therapeutic payload to the local wound, for example, fibroblast growth factor- 2 which stimulates angiogenesis by activating capillary endothelial cells and fibroblasts. The potential use of chitosan in this topic is, however, limited due to is poor solubility in water, faster in vivo depolymerization/degradation, hemo-incompatibility, and also weak antimicrobial property. To overcome these problems, chitosan derivatives have been proposed as novel scaffold materials for tissue engineering. A discussion on the use of many derivatives in bone tissue engineering as emerging products can be found in the recent reviews by LogithKumar et al. (2016) and by Ahmed et al. (2018).

For bone regeneration, several injectable materials were used. Chitosan-calcium phosphate composites appear to have a promising clinical application. Chemically modified hyaluronic acid-chitin and chitosan-hyaluronic acid material were reported to be osteoinductive and exhibited rapid degradation and neovascularization in vivo. Chitosan scaffolds are potentially a useful alternative to synthetic cell scaffolds also for cartilage tissue engineering. Anitha et al. (2014) reviewed the use of chitosanbased membranes and scaffolds not only for tissue engineering and wound healing but also as anticancer drug delivery, osteogenic drug delivery, and growth factor delivery. The key features of these biomaterials are their biodegradability, cytocompatibility, multi-functionality and specific mechanical properties. n-Laurylcarboxymethylcellulose has been proposed as carrier for hydrophobic cancer drugs. This amphiphilic substance is safe in terms of membrane toxicity. Materials for cancer chemotherapy are important but still under development (Saneja et al. 2016). Chitosan-based biomaterials were proposed against diabetes and related complications (Kim and Karadeniz 2013; Kim and Pangestuti 2013; Karadeniz and Kim 2014a, b) and also as new adhesives (Mati-Baouche et al. 2014).

Chitosan is a biocompatible substance with no antigenic properties, and thus it is perfectly compatible with living tissues. Its hemostatic and antithrombogenic bioactivities make it suitable in all fields of medicine: for controlled drug release, drugs encapsulation, enzymes and cells immobilization, and also as gene carriers. Chitosan is biodegradable and enzymes break it down into oligo-products that are then dealt with by the metabolism. Many chitosan derivatives are also biocompatible and nontoxic with living tissues. Other advantages of chitosan-based materials often cited are related to their hydrophilic property, biodegradability, antibacterial activity, bioadhesivity, mucoadhesivity, and complexing property. Like alginate polysaccharide, chitosan has the characteristic of forming gels in addition to possessing viscosityrelated properties, complete biodegradability, and even anti-tumor influence. Chitosan forms films that are permeable to air. It facilitates cellular regeneration 
while protecting tissues from microbial attacks. Chitosan has also a stimulating effect on the regeneration of tissues. It is used in making an artificial skin for skin grafts on high degree burns and in surgical applications (suture threads). Chitosan can trap lipids at their insolubilisation $\mathrm{pH}$ in the digestive tract. It considerably reduces the level of cholesterol in the blood. Chitosan possesses bioadhesive properties which make it of interest in adhesive sustained release formulation required. Mucoadhesivity permit to enhance the adsorption of drugs especially at neutral $\mathrm{pH}$ (Dash et al. 2011; Liu et al. 2011; Dutta 2016; Amber Jennings and Bumgardner 2017a, b; Vunain et al. 2017).

Genetic materials such as deoxyribonucleic acids and ribonucleic acid are used in gene therapy as pharmaceutical agents to treat various diseases (Lee 2007; Dash et al. 2011; Kedjarune-Leggat and Leggat 2011; Choi et al. 2016; Badawy and Rabea 2017). However, the use of genetic materials is limited due to rapid degradation by nuclease, large size, poor cellular uptake, high anionic charge density, and also non-specificity. To overcome these problems, non-viral vectors as cationic chitosan were proposed as promising delivery biomaterials in gene therapy (KedjaruneLeggat and Leggat 2011). Chitosan is a prominent system-based gene delivery vector due to its facility to form complexes, biodegradability and biocompatibility, although its transfection efficiency and cell specificity are low. Its role in gene delivery is supported by its ability to protonate in acidic media forming a complex with deoxyribonucleic acids through electrostatic interactions (Choi et al. 2016). The chitosan-deoxyribonucleic acids complexes are easy to prepare and are more effective compared to the commonly used systems. Chitosan/deoxyribonucleic acids complexes were reported to transfect into various cell types: human embryonic kidney cells, cervical cancer cells, primary chondrocytes, and fibroblast cells. As recently reviewed by Badawy and Rabea (2017), the transfection efficiency of chitosan depends on the degree of acetylation, molecular weight, $\mathrm{pH}$ of the transfecting media, cell type, and the charge ratio between the luciferase plasmid to chitosan. Limitations in the use of chitosan for non-viral gene therapy were previously reported by Kedjarune-Leggat and Leggat (2011). Most of the results on gene therapy using chitosan were obtained from experiments in vitro and further research is needed in vivo. In addition, studies still need to understand the effects of the characteristics of the carriers on cellular entry and intracellular trafficking processes (Choi et al. 2016).

Sulfated chitosan has the ability to interfere with blood clotting process. This is a subject of extensive medical applications. Compared to heparin, this derivative has been shown to possess high anticoagulant potency. Unlike heparin, sulfated chitosan does not show anti-platelet activity, which causes excessive bleeding in patients (Badawy and Rabea 2017). Another example of extensive medical studies concern the production of chitosan-based vaginal tablets used as drug delivery systems due to their adequate release properties and good adhesive properties (El-Kamel et al. 2002; Raafat and Sahl 2009; Bernkop-Schnürch and Dünnhaupt 2012). However, as claimed by Raafat and Sahl (2009), the antimicrobial properties of chitosan might have a negative impact on the vaginal microflora. Its vaginal use for treatment of chronic diseases has therefore to be seen with caution. Another application related 
to chitosan is based on the fact its modified particles provide an excellent template for bio-imaging. Chitosan-based nanoparticles containing imaging agents were studied for radiopharmaceutical applications and magnetic resonance imaging (Kumar et al. 2004; Dash et al. 2011).

The medical and biomedical potential applications of chitosan also include ophthalmology, dentistry, and veterinary medicine. In ophthalmology, due to their nontoxic character and permeation enhancing properties, chitosan-based formulations are used as drug delivery systems including coated colloidal systems, hydrogels, and nanoparticles (Bernkop-Schnürch and Dünnhaupt 2012; Elieh-Ali-Komi and Hamblin 2016; Krishnaswami et al. 2018). Chitosan possesses all the characteristics required for making an ideal contact lens: optical clarity, mechanical stability, optical correction, gas (oxygen) permeability, wettability and immunological compatibility (Elieh-Ali-Komi and Hamblin 2016; Badawy and Rabea 2017). The antimicrobial activity, film-forming ability, and wound-healing properties also make chitosan suitable for development of ocular bandage-lenses for traumatic injuries (Elieh-Ali-Komi and Hamblin 2016).

\subsubsection{Dentistry}

The relevant properties of chitosan cited for dentistry are: bioactivity, antiinflammatory, wound healing, hemostatic activities and bone repair (Queiroz et al. 2015; Kmiec et al. 2017; Navarro-Suarez et al. 2018; Zheng et al. 2018). Chitosan is used in the form of solution (acetic or methanesulfonic acid used as solvents), microspheres, hydrogel and toothpastes, and its association with additives such as amorphous calcium phosphate, amelogenin and quinic acid improved the ability of these chitosan preparations in preventing dental caries and enamel erosion. Its applications in dentistry are described in Table 2.12. Chitosan in gel/hydrogel form applies to the treatment of chronic periodontitis and canker sores. Due to its inherent versatility, efficiency and ability to act as a protective barrier to the penetration of acids into enamel and its mineral loss, chitosan can play an important role in preventive dentistry. In addition, when associated with remineralizing agents, chitosan preparations are able to repair early caries lesions (Queiroz et al. 2015). Toothpastes, mouthwashes and chewing gums based on chitosan and herbs fullness functions antimicrobial effect on oral bio film and reduction of the number of Streptococcus mutans in the oral cavity (Kmiec et al. 2017). They freshen the breath and prevent the formulation of plaque and tooth decay. Salts of chitosan added to tooth paste mask the unpleasant taste of silicon oxide and bind powders, so that they maintain their granular shapes. Chitosan complex and fluoride microparticles increase fluoride absorption and protection cavities. Endodontic cements based on chitosan reduces inflammation and support bone regeneration. Navarro-Suarez et al. (2018) recently discussed the use of nanotechnology in dentistry and the latest innovations in nanobiomaterials products. Zheng et al. (2018) also reviewed the application of biomaterials in dentistry, with a focus on new techniques using a 
Table 2.12 Applications of chitosan and its oligosaccharides in dentistry

\begin{tabular}{|c|c|c|}
\hline Topic & Form & Applications \\
\hline $\begin{array}{l}\text { Dental surgery } \\
\text { Dental therapy } \\
\text { Dental materials } \\
\text { Implants } \\
\text { Drug delivery systems } \\
\text { Oral hygiene } \\
\text { Antibacterial effect } \\
\text { Restorative dentistry } \\
\text { Dental composites } \\
\text { Wound healing } \\
\text { Nanodentistry }\end{array}$ & $\begin{array}{l}\text { Solution } \\
\text { Hydrogel } \\
\text { Toothpastes } \\
\text { Bioadhesive } \\
\text { Powder } \\
\text { Granule } \\
\text { Nanoparticle } \\
\text { Sponge } \\
\text { Composites }\end{array}$ & $\begin{array}{l}\text { Agent to prevent diseases: dental caries, } \\
\text { periodontitis, erosive lesion, dental plaque inhibitor } \\
\text { Ingredient in dentifrices } \\
\text { Oral care, dental care: toothpaste, chewing gum } \\
\text { Chitosan-containing chewing gum having } \\
\text { antibacterial effects or to increase salivary secretion } \\
\text { Delivery of fluoride } \\
\text { Dental adhesives } \\
\text { Nanobiomaterials } \\
\text { Agent to promote wound healing in bone tissue } \\
\text { Scaffolds and carriers for molecular therapy } \\
\text { Cell protective activity }\end{array}$ \\
\hline
\end{tabular}

\section{References}

Sapelli et al. (1986), Khor and Lim (2003), Stamford Arnaud et al. (2010), Hayashi (2011), Keegan et al. (2012), Hayashi et al. (2013), Farea et al. (2014), Queiroz et al. (2015), Kmiec et al. (2017), Wieckiewic et al. (2017), Elkassas and Arafa (2017), Ahsan et al. (2018), Navarro-Suarez et al. (2018), and Zheng et al. (2018)

combination of scaffolds, cells and biologically active molecules to assemble functional constructs that restore, maintain or improve damaged tissues for dental purposes.

\subsubsection{Veterinary Medicine}

Senel and McClure (2004) previously reviewed the applications of chitosan in veterinary medicine including wound healing, bone regeneration, analgesic and antimicrobial effects. They also discussed the potential application of chitosan to drug and vaccine delivery in veterinary species, and as nutritional ingredient. Given the restrictions imposed by financial and animal restraint considerations, especially in fanning applications, the veterinary drug delivery areas most likely to benefit from chitosan are the delivery of chemotherapeutics such as antibiotics, antiparasitics, anaesthetics, painkillers and growth promotants to mucosal epithelium for absorption for local or systemic activity, and the delivery of immunomodulatory agents to the mucosal associated lymphoid tissue for induction or modulation of local immune responses. Other applications in veterinary medicine are showed in Table 2.13. The use of nanoparticles for drug delivery, diagnostics and vaccine formulation has described by Underwood and van Eps (2012). Nanomedicine using innovative nanosystems seems to be a promising domain. Products have already reached the market. For instance, chitosan-based nutritional supplements (Epakitin ${ }^{\mathrm{TM}}$, Nutri+Gen $\left.{ }^{\circledR}\right)$ are commercially available for use as essential nutrients supplement or in chronic kidney disease in dogs and cats. The Epakitin formulation containing both chitosan and calcium carbonate is a safe and highly palatable kidney-protective 
Table 2.13 Applications of chitosan and its oligosaccharides in veterinary medicine

\begin{tabular}{l|l|l}
\hline Topic & Forms & Applications \\
\hline Delivery systems & Solution & Time release drugs for animals \\
Vaccine delivery & Powder & Mucosal formulations \\
Adjuvant & Microsphere & Mucosal delivery of antigens \\
Biological properties & Microcapsule & Improve the immune response \\
Mucosal immunization & Nanoparticle & Hemostatic \\
Wound healing & Gel, hydrogel & Wound-healing activity \\
Tissue regeneration & Sponge & Regenerative medicine: tissue engineering \\
Nutritional supplement & Film & Vaccines \\
Nanomedicine & Filament & Surgical threads \\
& & Food for dogs \\
& & Reduce urea levels \\
& & Body-care products: shampoo, sprays \\
\hline
\end{tabular}

\section{References}

Şenel and McClure (2004), Şenel (2011), Underwood and van Eps (2012), Drewnowska et al. (2013), Gerdts et al. (2013), Tonda-Turo et al. (2016)

phosphate binder. Many body care are also available (ChitoCure®, ChitoClear ${ }^{\circledR}$ ): shampoo, ear-cleaner, conditioner, sprays for companion animals, etc.

\subsubsection{Cosmetics}

It is possible to produce chitosans as well as chitosan derivatives with varying chain lengths and differentiated properties for applications in cosmetics, hygiene and personal care. The molecular weight of most chitosan products are so high that they cannot penetrate the skin and this is an important advantage that make it suitable for skin care. These materials include chitosan hydrochloride, chitosan acetate, chitosan lactate, carboxymethyl-chitosan, quaternized-derivatives, oligosaccharides, and also chitin sulphate and carboxymethyl-chitin. They can be dissolved in aqueous solutions or used in solid form. In cosmetics, the specific properties employed are: cationic (chitosan and hair carry opposite electrical charges), bacteriostatic, fungistatic, antistatic, film-forming, moisture-retaining (chitosan retain moisture in low humidity and maintain hair's style in high humidity), and controlled release of bioactive agents. Chitosan is also of great interest in cosmetic formulations because it is compatible with other ingredients such as starch, glucose, saccharose, polyols, oils, fats, waxes, acids, non-ionic emulsifiers and non-ionic water-soluble gums. However, chitosan is incompatible with ionic gums, sulphonated surface-active agents, alkalis, and sulphuric acids. Chitosan and its derivatives can be combined with other hydrating agents, solar filters and other bioactive products used in the formulations. They facilitate their effects. Some derivatives of chitosan can form foam and create emulsifying actions.

Some of the chitosan applications (Table 2.14) are: hair care, e.g. shampoos, coloring products, hairspray, and setting lotion, creams and lotions (face, hand and 
Table 2.14 Applications of chitosan and its oligosaccharides in cosmetics

\begin{tabular}{|c|c|c|}
\hline Topic & Form & Applications \\
\hline $\begin{array}{l}\text { Toiletry } \\
\text { Hygiene } \\
\text { Personal care } \\
\text { Skin care } \\
\text { Oral care } \\
\text { Dental care } \\
\text { Hair care } \\
\text { Cosmeceuticals } \\
\text { Fragrances } \\
\text { Essential oils }\end{array}$ & $\begin{array}{l}\text { Solution } \\
\text { Powder } \\
\text { Film }\end{array}$ & $\begin{array}{l}\text { Functional additives } \\
\text { Moisturizers: maintain skin moisture, tone skin } \\
\text { Thickening agent } \\
\text { Hydrating and film-forming agent } \\
\text { Role in surfactant stability; stabilize emulsion } \\
\text { Antistatic effect } \\
\text { Bacteriostatic } \\
\text { Encapsulating agent } \\
\text { Delivery systems } \\
\text { Products: shampoos, creams, skin creams, creams for acne } \\
\text { treatment, lotions, bath lotions, nail polish, fixtures, make-up } \\
\text { powder, lacquers, nail lacquers, nail enamel, varnishes, hair } \\
\text { sprays, hair colorants, wave agents } \\
\text { Cleaning products: cleansing milk, face peel, facial toner, soap, } \\
\text { bath agent } \\
\text { Hair care: elastic film on hair, increase its softness and } \\
\text { mechanical strength, improve suppleness of hair, remove oils } \\
\text { and sebum from hairs; reduce static electricity in hair, retain } \\
\text { moisture and maintain hair's style } \\
\text { Oral care, dental care: toothpaste, chewing gum }\end{array}$ \\
\hline
\end{tabular}

\section{References}

Goosen (1997), Struszczyk (2002), Rinaudo (2006), Crini et al. (2009), Muñoz et al. (2012), Lima et al. (2012), Senevirathne et al. (2012), Chalongsuk and Sribundit (2013), Jimtaisong and Saewan (2014), Costa and Santos (2017), and Rahangdale and Kumar (2018)

body products), color cosmetics (make-up, nail polish, eye shadow, and lipstick), deodorizing products, micro-encapsulation of active agents, and dental care, e.g. toothpaste, tooth-gel, and mouth wash. Chitin is also interesting in cosmetology because it is well tolerated by the skin. It is an effective hydrating agent and a filmforming tensor having two advantages often cited: it supplies water and it avoids dehydration. Chitosan and chitin also present chelating properties towards metals that are responsible for very many contact allergies. Carboxymethyl-chitosans products are mainly used in cosmetics as antioxidant agent, moisture absorptionretention agent, antimicrobial agent, delivery system and emulsion stabilization. Jimtaisong and Saewan (2014) comprehensively discussed the utilization of carboxymethyl-chitosans as multifunctional ingredients in the formulation of cosmetics. They also included in their review information on cytotoxicity of these products to ensure their safety.

Numerous chitosan-based products for cosmetic use are commercially available: Curasan $^{\mathrm{TM}}$, Hydamer ${ }^{\mathrm{TM}}$, Zenvivo ${ }^{\mathrm{TM}}$, Ritachitosan ${ }^{\circledR}$, Chitosan MM222, etc. Cosmetic industry is a strongly growing market. The cosmeceutical market has also

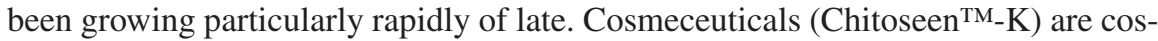
metics with pharmaceutical/medicinal benefits. These products seem to provide not only a health benefit but also cosmetic qualities. They contain essential oils and active ingredients such as vitamins, enzymes, antioxidants, and phytochemicals. They can be applied as creams, lotions and ointments (Lima et al. 2012; Muñoz 
et al. 2012; Senevirathne et al. 2012). Since the last decade, they continue to revolutionize the world of hair, lip, tooth and skin care by offering safe and natural ingredients for consumer's personal use.

\subsubsection{Agriculture}

Applications of chitosan in agriculture are summarized in Table 2.15. Chitosan products are used in plant protection from the 1990s against plant pathogenic bacteria that induce decay and harmful effects of agricultural crops during the growing season and postharvest phase (Yin and Du 2011). They behave as bactericidal (killing the bacteria) and/or bacteriostatic (hindering the growth of bacteria). However, the exact mechanism is still not fully understood. A discussion on models proposed for antibacterial actions of chitosan can be found in the review by Muñoz-Bonilla et al. (2014). The most accepted mechanism involves the polycationic character of chitosan which permits to interact with negatively charged species (bacterium cell membrane). The chelating properties of chitosan also make it an excellent antifungal agent (Rabea et al. 2003; Muñoz-Bonilla et al. 2014; Badawy and Rabea 2016; Divya and Jisha 2018). The presence of chitosan activates many defense responses in plants. Usually, it is employed in plant disease control as a powerful elicitor.

Table 2.15 Applications of chitosan and its oligosaccharides in agriculture

\begin{tabular}{l|l|l}
\hline Topic & Form & Applications \\
\hline Plant protection & Solution & Protection of plants \\
Antimicrobial agent & Spray & Coating material: seeds, fruits, vegetables \\
Antioxidant & Coating & Stimulation of plant growth and plant production \\
Horticulture & Powder & Increase of crop yields \\
Agrochemistry & Gel & Reduce the growth of phytopathogenic fungi \\
Soil enrichment & Powder & Effects on gene expression \\
Postharvest & Nanoparticle & Pest control \\
& & Soil treatment (nutrients) \\
& Modify plant-microbial interactions \\
& Elicitor to stimulate the accumulation of secondary \\
& metabolites and to induce plant defenses \\
& Frost protection \\
& Controlled agrochemical release \\
& Fertilizers and biocontrol agent (time release of \\
& products) \\
& Bio-fertilizer, fertilizer protectant \\
& Spray for pesticide removal (fruits) \\
& Pesticide formulations; biopesticides; biofungicides \\
\hline
\end{tabular}

\section{References}

Goosen (1997), El Hadrami et al. (2010), Yin and Du (2011), Sharp (2013), Muñoz-Bonilla et al. (2014), Katiyar et al. (2014), Xing et al. (2015), Badawy and Rabea (2016, 2017), Bautista-Baños et al. (2016), Hadwiger (2017), Ippólito et al. (2017), Orzali et al. (2017), Divya and Jisha (2018), Grande-Tovar et al. (2018), and Sharif et al. (2018) 
Chitosan products were proposed as devices for controlling the release of agrochemicals (fertilizers, pesticides). They are used as biocides either alone or blended with other products against plant diseases (control of plant bacteria and fungi), pests and insects, plant growth promotion, seed-coating, and postharvest (Divya and Jisha 2018; Grande-Tovar et al. 2018; Sharif et al. 2018). Chitosan has also inhibitory effect on viruses and viroid of plants. It has a great potential as biopesticide. It can function as a seed-soaking agent, a root-applying agent, and a spray agent. These activities play an important role on plant disease control and stress resistance. Blending of chitosan with other products, such as gum, starch, and alginate, is a convenient method to improve its properties for slow release of pesticides. The use of chitosan products can elicit defense to more than 60 diseases on several plants. Their potent effect on plant disease control is from their antimicrobial and plant innate immunity elicited activity. The inhibition activity was observed on different stages of fungal growth such as mycelia, sporulation, spore viability and germination, and production of fungal virulence factors. Chitosan products can be used in various ways: coating seed (soybean, cotton, cucumber, wheat, rice), soil enrichment (for potato, soybean lettuce, spinach), foliar spraying (for peanut, soybean, cabbage, rice, maize, cotton), supplement in hydroponic (rice, wheat, peanut), and supplement in plant tissue culture medium (Chrysanthemum, Limonium, carrot). As seed coating agent, they protect plants, e.g. cotton, tomato, wheat, and have a positive effect on germination rate, seedling growth parameters, and the yield of different cultivars, e.g. soybean sprouts, ornamental plants, maize, wheat, lentil, rice, and peanut. Their bioactivities as antifungal activity, enhancement crop yield, induction of defensive system of plants and plant-growth promotion play key roles in their application for agriculture.

The two main problems of chitosan in agriculture applications are commercial chitosan standardization and solubility. Indeed, chitosan bioactivities are dependent on several parameters including degree of acetylation, molecular weight, concentration of chitosan, $\mathrm{pH}$ of the solution, its viscosity, and the target of microorganism. The antimicrobial activity of non-modified chitosan against various microorganisms such as bacteria, yeasts, fungi and viruses has received much attention in the last two decades. The literature data showed that this bioactivity property depends on various factors such as molecular weight, which is probably the main factor affecting the efficacy, although literature is sometimes contradictory. Generally, the antibacterial activity increase as the molecular weight decreases. However, it is difficult to find a clear correlation between the molecular weight and this bioactivity (Badawy and Rabea 2017). In spite of its unique biological aspects, the waterinsoluble property is another major limiting factor for its wide application in agriculture. Recently, to overcome these problems, chitosan derivatives and oligomers produced by enzymatic and chemical modifications have been proposed. It is expected that these biopolymers would be promising candidates in agriculture. Research are also in progress on the mechanisms of chitosan-induced defense and on the signal perception of chitosan. Nanotechnology using innovative chitosan nanoparticles seems to be a promising domain. The methods of preparation of 
chitosan nanoparticles and their potential applications as antimicrobial agent, plant growth-promoting agent and plant protector have been discussed in the recent review by Divya and Jisha (2018).

\subsubsection{Aquaculture}

A prerequisite for the greater use of chitin in industry is cheap manufacturing processes and/or the development of profitable processes to recover chitin and byproducts such as proteins and pigments. It is well-known that the recovery of chitinous products from wastes is an additional source of revenue. Crustacean shells contain considerable quantities of carotenoids which so far have not been synthesized, and which are marketed as a fish food additive in aquaculture, mainly for salmon. The use of chitosan and its derivatives in the aquaculture was described by Alishahi and Aïder (2012). It can be used as functional food, nutritional supplements (synbiotics), carrier abilities for bioactive compounds, drug release, encapsulation of pathogens or nucleic acids, and for pollutant removal from water and wastewaters (Table 2.16). There is also a constant need for the development of efficient vaccines and delivery systems to prevent and control the emerging and re-emerging infectious diseases in aquaculture. There are innumerable infectious diseases for which the development of efficient vaccines has been difficult to achieve. The failure is mainly due to the inability to design vaccines evoking appropriate immune responses. The use of chitosan-based nanoparticles has provided a tremendous opportunity to design vaccine delivery systems that are efficient in targeted delivery, providing stability to antigens, and act as efficient adjuvants. Many of the

Table 2.16 Applications of chitosan in aquaculture

\begin{tabular}{|c|c|c|}
\hline Topic & Form & Applications \\
\hline $\begin{array}{l}\text { Quality water } \\
\text { Nutrition } \\
\text { Functional foods } \\
\text { Nutritional supplements } \\
\text { Probiotics/Prebiotics } \\
\text { Controlled release of } \\
\text { compounds } \\
\text { Treatment of seafood } \\
\text { effluents }\end{array}$ & $\begin{array}{l}\text { Powder } \\
\text { Microsphere } \\
\text { Bead }\end{array}$ & $\begin{array}{l}\text { Removal of organic compounds and inorganic } \\
\text { nutrients; removal of bacteria, of ammonia } \\
\text { Functional food; to enhance gelling properties } \\
\text { Micro-carrier abilities for bioactive compounds: } \\
\text { proteins, pigments } \\
\text { Probiotics to improve feed conversion, growth } \\
\text { rates, weight gain, immune system and disease } \\
\text { resistance of fish } \\
\text { Microencapsulation of drugs and drug delivery; } \\
\text { oral delivery (vaccination) } \\
\text { Immuno-stimulant against bacterial diseases } \\
\text { Antimicrobial, antioxidant and antioxidative } \\
\text { stress }\end{array}$ \\
\hline
\end{tabular}

\section{References}

Chung et al. (2005), Chung (2006), Borgogna et al. (2011), Cerezuela et al. (2011), Alishahi and Aïder (2012), Harikrishnan et al. (2012), Niu et al. (2013), Zaki et al. (2015), Lian et al. (2016), and Bernardi et al. (2018) 
nanoparticles are able to enter the antigen presenting cells by different pathways and induce appropriate immune responses to the antigen. Vinay et al. (2018) reviewed the use of chitosan for the delivery of fish vaccines and compared the potential of these delivery systems for the development of new vaccines against different fish pathogens.

\subsubsection{Textile Industry}

Applications of chitosan and its derivatives in textile industry are described in Table 2.17. Among the possible approaches initiated by the textile industry, the use of chitosan presents an innovative possible avenue for large scale development of bioactive textiles (Giri Dev et al. 2005; Enescu 2008; Sahan and Demir 2014; Gutiérrez 2017; Roy et al. 2017). Indeed, more research and practical use results indicate that chitosan might act as active compounds in textiles, e.g. as antimicrobial finishing of textiles, and cosmetotextiles. The characteristics of chitosan used in textile industry include cost-effectiveness, non-toxic, biocompatible, biodegradable, antimicrobial activity, antistatic activity, chelating property, deodorizing property, film-forming ability, chemical reactivity, dyeing improvement ability, thickening property, and also wound healing activity. Although the antimicrobial activity of chitosan is well document in the literature, its mode of action is yet not fully understood (Islam et al. 2013). There are many possibilities for the development of new textile and cosmetic products containing chitosan-based nanoparticles with advanced properties (UV-blocking, water repellence, self-cleaning). Their applications seem promising.

Table 2.17 Applications of chitosan and its derivatives in textile industry

\begin{tabular}{l|l|l}
\hline Topic & Forms & Applications \\
\hline Textiles & Microcapsule & Dye-binder for textiles \\
Functional textiles & Gel & Impregnated textile materials \\
Cosmeto-textiles & Gelatinous dispersion & Binding agent for non-woven \\
Medical textiles & Coating & Surface modification of textiles \\
& Fiber & Textiles with anti-bacterial properties \\
& & Textile printing and antimicrobial finishing \\
& & Textile preservative and deodorant agent \\
& & Non-allergenic fibers \\
& & Sanitary fibrous products \\
& & Surgical threads \\
\hline
\end{tabular}

\section{References}

Giri Dev et al. (2005), Enescu (2008), Ummu Habeeba et al. (2007), Crini et al. (2009), Francesko et al. (2010), Islam et al. (2013), Şahan and Demir (2014), Hamed et al. (2016), Voncina et al. (2016), Gutiérrez (2017), and Roy et al. (2017) 
Table 2.18 Applications of chitosan and its derivatives in pulp and paper industry

\begin{tabular}{l|l|l}
\hline Topic & Form & Applications \\
\hline Papermaking industry & Coating & Wet strength agent; strengthening additive \\
Pulp and paper & Powder & Retention and drainage agents \\
Water treatment & Nanoparticle & Paper sizing and finishing \\
Papermaking-related & & Surface coating application: coated papers with \\
industries & antibacterial and antimicrobial properties \\
& & Confer strength to paper against moisture \\
& Biodegradable packaging for food wrapping \\
& Wrapping and toilet paper \\
& Chromatography paper \\
& Card board \\
& Carbonless copy paper \\
& Modification of cellulose fibers \\
& Photochromic paper \\
& Papermaking wastewater treatment \\
\hline
\end{tabular}

References

Muzzarelli (1983), Struszczyk (2002), Crini et al. (2009), Cheba (2011), Samyn et al. (2018), and Song et al. (2018)

\subsubsection{Pulp and Paper Industry}

Applications of chitosan in pulp and paper industry are described in Table 2.18. The first use of chitosan in the papermaking industry was reported in 1936 (Struszczyk 2002). The main use was to improve wet-strength of paper. Chitosan as functional material is also able to interact with cellulose pulp during the formation of paper and to be film-forming to offer cohesive resistance to rupture (Song et al. 2018). This biopolymer is also non-toxic, biodegradable and eco-friendly in order to facilitate compliance with environmental regulations. Chitosan as chelating and complexing agent is also used in the decontamination of pulp and paper wastewaters for removal of lignin, color and undesired contaminants, and for the decrease in total organic carbon and chemical oxygen demand. Samyn et al. (2018) recently reviewed the use of nanoparticles and nanostructured materials in papermaking.

\subsubsection{Biotechnology}

Some applications of chitosan in biotechnology are described in Table 2.19. Numerous enzymes (lysozyme, urease, Escherichia coli cells, amylases) were immobilized with chitosan. They are entrapped and absorbed in the macromolecule chains. In biochemistry, chitosan is used as a support for enzymes, mainly by crosslinking reactions. Chitosan and its derivatives have also shown biotechnology applications as biosensors and biodevices. Depolymerization and de-N-acetylation of chitin by chitinases and deacetylases generates a series of derivatives such as 
Table 2.19 Applications of chitosan and its derivatives in biotechnology

\begin{tabular}{l|l|l}
\hline Topic & Form & Applications \\
\hline Enzymology & Powder & Enzyme and cell immobilization \\
Enzyme technology & Bead & Cell recovery \\
Separation & Microsphere & Cell-stimulating materials \\
Bioseparation & Nanoparticle & Protein separation \\
Biomembranes & Sponge & Matrix for affinity and gel permeation \\
Electrodes & Membrane & chromatography \\
Biosensors & & Electronic devices, biosensor construction \\
& & Metabolic analysis of biological fluids \\
\hline
\end{tabular}

References

Zikakis (1984), Struszczyk (2002), Krajewska (2005), Wang (2012), Suginta et al. (2013), Philibert et al. (2017), and Grifoll-Romero et al. (2018)

chitooligosaccharides which find numerous applications in biotechnology as recently reviewed by Grifoll-Romero et al. (2018).

\subsubsection{Chemistry}

Table 2.20 describes some applications of chitosan in chemistry. Chitosan is the object of numerous studies concerning applications in chromatography, green chemistry, catalysis, membrane technology and electrochemistry. It has been proposed in thin layer chromatography for separation of nucleic acids and in green chemistry for the generation of green solvents. It is believed that chitosan will play a very important role in these new developments. The utilization of chitosan as a catalyst support is also of particular interest. This application combines several upto-date techniques (freeze drying, utilization of supercritical $\mathrm{CO}_{2}$ ) to increase the surface exchange capabilities and/or utilization of ionic liquids. Chitosan contributes to the implementation of green chemistry principles. The state of the art review of the design of electrochemical biosensor applications based on chitosan and chitin was presented by Suginta et al. (2013) and comprehensively discussed. Membranes are produced by casting chitosan solutions either alone or with suitable ingredients (reagents, polymers) to give desired properties for target applications. Preparation and application of chitosan-based adsorptive membranes for separation and for water purification were reviewed by Salehi et al. (2016) and by Thakur and Voicu (2016), respectively. Chitosan has been proposed for the separation of organic liquid mixtures using evapomeation membranes. This membrane separation technique makes use of the advantage of pervaporation and simultaneously removes a fault of pervaporation. The main applications of chitosan membranes are their use in biomedicine and biotechnology. Albumin blended chitosan membranes have been used in hemodialysis, artificial skin and also drug targeting. Further developments are expected in the near future in these domains (Galiano et al. 2018). 
Table 2.20 Applications of chitosan and its derivatives in chemistry

\begin{tabular}{l|l|l}
\hline Topic & Form & Applications \\
\hline Analytical chemistry & Solution & Analytical reagent \\
Chromatography & Ionic liquids & Reverse osmosis \\
Dialysis & Powder & Permeability control \\
Reverse osmosis & Film & Solvent separation \\
Ultrafiltration & Coating & Organic/organic separation \\
Gas permeation & Fiber & Alcohol/water selective pervaporation \\
Pervaporation & Membrane & Transport direction of target molecules \\
Evapomeation technique & Composite & Membranes for lithium batteries \\
Carrier transport membranes & Blend & Biosensors, electrochemical devices \\
Green chemistry & Sensors & CO recovery \\
Green solvents & & Alternative solvents in catalytic organic \\
Catalysis/Biocatalysis & & reactions \\
Adhesives & & Adhesive role between metallic \\
Corrosion protection & & surfaces \\
Polymer science & & Corrosion protection of aluminum \\
Click chemistry & & Ionic liquids \\
Electrochemistry & & Deep eutectic solvents \\
\hline Referencs & &
\end{tabular}

\section{References}

Goosen (1997), Guibal (2005), Krajewska (2005), Macquarie and Hardy (2005), Li et al. (2008), Crini et al. (2009), Cheba (2011), Dash et al. (2011), Suginta et al. (2013), MatiBaouche et al. (2014), Carneiro et al. (2015), Salehi et al. (2016), Thakur and Voicu (2016), Osman and Arof (2017), Argüelles-Monal et al. (2018), Galiano et al. (2018), Marpu and Benton (2018), Xie and Yuan (2018), and Zdanowicz et al. (2018)

\subsubsection{Environmental Chemistry}

A growing number of papers have been published since the 1980s concerning chitosan for applications in environmental chemistry (Table 2.21). This natural polymer possesses several intrinsic characteristics that make it an effective material for environmental purposes. Its use is justified by four important advantages:(i) its relatively low cost compared with commercial activated carbon or organic resins, (ii) its outstanding pollutant-binding capacities and excellent selectivity, (iii) its versatility, and (iv) its possible biodegradability after use. Indeed, one of the major applications of chitosan is based on its great ability to tightly bind a whole range of pollutants. In addition, chitosan and its derivatives can be used in soluble or insoluble forms including gels, beads, sponges, films and membranes, and fibers through coagulation-, filtration-, flocculation- or adsorption-oriented processes. In a previous review, Crini and Badot (2008) comprehensively discussed the development of chitosanbased materials (grafted and crosslinked derivatives) used as useful adsorbent polymeric matrices for dye removal. Their review highlighted results that have been obtained in their decolorizing application as biosorbents. The effects of various parameters such as chitosan's characteristics, the activation conditions, the process variables, the chemistry of the dye and the experimental conditions used in batch systems, on biosorption were presented and discussed. The authors also reviewed the various adsorption mechanisms involved. They concluded that the biosorbents 
Table 2.21 Main applications of chitosan and its derivatives in environmental chemistry (selected reviews)

\begin{tabular}{|c|c|c|}
\hline Topic & Form & Applications \\
\hline $\begin{array}{l}\text { Water treatment } \\
\text { Wastewater } \\
\text { treatment } \\
\text { Coagulation } \\
\text { Flocculation } \\
\text { Adsorption } \\
\text { Biosorption } \\
\text { Solid-phase } \\
\text { extraction } \\
\text { Filtration } \\
\text { Membrane filtration } \\
\text { Remediation } \\
\text { Biological } \\
\text { denitrification }\end{array}$ & $\begin{array}{l}\text { Solution } \\
\text { Gel/hydrogel } \\
\text { Powder } \\
\text { Microsphere } \\
\text { Bead } \\
\text { Nanoparticle } \\
\text { Fiber } \\
\text { Hollow fiber } \\
\text { Membrane } \\
\text { Sponge }\end{array}$ & $\begin{array}{l}\text { Coagulant/Flocculant: clarification of drinking water, } \\
\text { pools and spas, wastewaters } \\
\text { Adsorbent/Biosorbent: recovery of precious metals; } \\
\text { metal chelation; dye removal; removal of pesticides, } \\
\text { phenol derivatives, PCB and radioisotopes } \\
\text { Interactions with proteins and amino acids } \\
\text { Reduce odors } \\
\text { Antifouling agent } \\
\text { Polymer-assisted ultrafiltration } \\
\text { Sludge treatment and dehydration agent } \\
\text { Drilling muds }\end{array}$ \\
\hline
\end{tabular}

\section{References}

Hirano (1997), Varma et al. (2004), Crini (2005, 2006, 2015), Krajewska (2005), Tang et al. (2007), Gérente et al. (2007), Alves and Mano (2008), Crini and Badot (2008), Li et al. (2008), Bhatnagar and Sillanpää (2009), Elwakeel (2010), Sudha (2011), Rhazi et al. (2012),

Ravichandran and Rajesh (2013), Vakili et al. (2014), Liu and Bai (2014), Boamah et al. (2015), Yong et al. (2015), Azarova et al. (2016), Barbusinski et al. (2016), Kos (2016), Ahmad et al. (2017a, b), Crini et al. (2017), Sudha et al. (2017), Nechita (2017), Alaba et al. (2018), de Andrade et al. (2018), Desbrières and Guibal (2018), El Halah et al. (2018), Pakdel and Peighambardoust (2018), Van Tran et al. (2018), and Wei et al. (2018)

were efficient in pollutant removal with the additional advantage of being cheap, non-toxic and biocompatible. More recently, Kyzas et al. (2017), Desbrières and Guibal (2018) and Pakdel and Peighambardoust (2018) also indicated that biosorption onto chitosan is a promising alternative to replace conventional adsorbents used for decolorization purposes, and metal and organic removal. Chitosan-based versatile materials are also widely proposed in clarification and water purification, and water and wastewater treatment as coagulating and flocculating agents (Crini et al. 2009). As ecofriendly materials, they can be a potential substitute for metallic salts and synthetic polyelectrolytes in the treatment of water for the removal of both particulate and dissolved substances. However, despite a large number of studies on the use of chitosan for pollutant recovery in the literature, processes are basically at the stage of laboratory-scale study in spite of unquestionable progress. Indeed, these research fields for chitosan have failed to find practical applications on the industrial scale. The actual applications in industry remain rather rare, e.g. Pennofloc ${ }^{\mathrm{TM}}$ for water clarification, ChitoVan ${ }^{\mathrm{TM}}$ for biofiltration, as concurrent flocculating and adsorbing agents are cheaper. Even if chitosan shows better performances in term of pollutant elimination, the conventional products are sufficient to fulfill current regulatory frameworks. 


\subsubsection{Miscellaneous}

Table 2.22 describes applications of chitosan in miscellaneous domains. Due to its optical characteristics, film-forming ability and reactions with silver complexes, chitosan and derivatives found applications in photography. In color photography, chitosan has been proposed as a fixing agent for acid dyes in gelatin and also acts as an aid to improve diffusion (Dutta et al. 2004). Ecological concerns about antifouling paints containing non-green tin and copper compounds have highlighted the need for environmentally friendly alternatives (Pelletier et al. 2009; Banerjee et al. 2011). Novel chitosan-based technologies may prevent fouling by means of unfavorable surface chemical and physical properties or by concentrating antifouling compounds around surfaces. A prototype of antifouling paints was proposed as a possible replacement for traditional antifouling paints by Heuser and co-workers (Heuser et al. 2009; Heuser and Cárdenas 2014). In cement industry, chitosan has been proposed as water proofing and water repellent (Cheba, 2011). Chitosan has been also explored in the production of plastics (Galiano et al. 2018) or in the stabilization of photonic materials (Marpu and Benton 2018).

Table 2.22 Applications of chitosan in miscellaneous domains

\begin{tabular}{l|l|l}
\hline Field & Main form & Applications \\
\hline Photography & Solution & Photographic paper \\
Detergents & Powder & Film forming ability \\
Surfactants & Coating & Fixing agent for color photography \\
Paints & Nanoparticles & Color film \\
Adhesives & Nanoclusters & Nanoimprinting lithography \\
Wood industry & & Antifouling paints \\
Cement industry & Thermosensitive materials \\
Leather & Improvement of wood quality \\
Plastics & & Wood adhesive \\
Bioplastics & Protection of wood (fungicide) \\
Cigarette industry & Lithium batteries \\
Semiconductors & & Specific targeting \\
Luminescent nanoparticles & Cellular imaging \\
Photonics & & Bio-imaging and cancer research \\
Imaging applications & Bioconjugation to biomolecules \\
Quantum dots & Sensors and biosensing \\
Carbon dots & & Temperature sensing \\
\hline
\end{tabular}

\section{References}

Struszczyk (2002), Crini et al. (2009), Elsabee et al. (2009), Heuser et al. (2009), Pelletier et al. (2009), Desbrières et al. (2010), Banerjee et al. (2011), Cheba (2011), Heuser and Cárdenas (2014), Mati-Baouche et al. (2014), Al-Naamani et al. (2017), Argüelles-Monal et al. (2017), Galiano et al. (2018), and Marpu and Benton (2018) 


\subsection{Conclusion}

Isolated from mushrooms in 1811 by Braconnot, chitin is the first polysaccharide identified by man, preceding cellulose by about 30 years, while its deacetylated derivative was discovered by Rouget in 1859. In 1894, Hoppe-Seyler confirmed that the product was deacetylated chitin and named it chitosan. Since, these biopolymers, in particular chitosan, have considerably attracted the interest of scientists and industries in different disciplines including health science, agriculture, chemistry, biochemistry, and environment. The main reasons for this growing interest are its intrinsic biological properties and its versatility as biomaterial. Today, chitosan continue to offer new horizons to scientists and industrials with a wide range of possible modifications and forms. In this chapter, we aim to present an overview of the state of the art in the applications of chitosan, based on a substantial number of relevant references published in the last two decades on various biological, biotechnological, chemical, and physical topics for both academic and industrial applications. Of course, this is an ambitious project and the examples discussed in this chapter are not exhaustive but clearly demonstrate the benefit of chitosan in many fields. The main markets for chitosan are food, pharmaceutical and cosmetic industries. The chitosan market is expected to grow rapidly because of increasing consumption not only in cosmetics but also in water treatment, beverage industry, and nutrition. Indeed, nutraceuticals and cosmeceuticals are growing actual markets. There is also an increased demand for chitosan in emerging countries. Therapeutic and biomedical products are also expected to have a positive impact on the market. It is important to point out that, although numerous papers and patents have been reported in the last two decades, the applications of chitosan in the biomedical area are still limited, mainly due to the extreme difficulty to access sufficient purity and source reliability of the biopolymer. In addition, the development of new materials are rather limited, mainly due to their cost, which remains higher than that of petroleum based polymers with similar properties. Finally, in vivo studies are currently limited. Further industrial developments are expected in the near future in the following domains: anticancer drugs, gene delivery, catalysis, sensor applications, wrapping materials and packaging, cosmetotextiles, and bio-imaging.

\section{References}

Abdou ES, Nagy KS, Elsabee MZ (2008) Extraction and characterization of chitin and chitosan from local sources. Bioresour Technol 99:1359-1367. https://doi.org/10.1016/j. biortech.2007.01.051

Abdul Khalil HPS, Saurabh CK, Adnan AS, Nurul Fazita MR, Syakir MI, Davoudpour Y, Rafatullah CK, Hafiz MKM, Dungani R (2016) A review on chitosan-cellulose blends and nanocellulose reinforced chitosan biocomposites: properties and their applications. Carbohydr Polym 150:216-226. https://doi.org/10.1016/j.carbpol.201605.028

Acosta N, Jiménez C, Borau V, Heras A (1993) Extraction and characterization of chitin from crustaceans. Biomass Bioenergy 5:145-153 
Agnihotri SA, Mallikarjuna NN, Aminabhavi TM (2004) Recent advances on chitosan-based micro- and nanoparticles in drug delivery. J Control Release 100:5-28. https://doi.org/10.1016/j. jconrel.2004.08.010

Agulló E, Rodriguez MS, Ramos V, Albertengo L (2003) Present and future role of chitin and chitosan in food. Macromol Biosci 3:521-530. https://doi.org/10.1002/mabi.200300010

Ahmad M, Manzoor K, Ikram S (2017a) Versatile nature of hetero-chitosan based derivatives as biodegradable adsorbent for heavy metal ions: a review. Int J Biol Macromol 105:190-203. https://doi.org/10.1016/j.ijbiomac.2017.07.008

Ahmad M, Manzoor K, Singh S, Ikram S (2017b) Chitosan centered bionanocomposites for medical specialty and curative applications: a review. Int J Pharm 529:200-217. https://doi. org/10.1016/j.ijpharm.2017.06.079

Ahmadi F, Oveisi Z, Mohammadi Samani S, Amoozgar Z (2015) Chitosan based hydrogels: characteristics and pharmaceuticals applications. Res Pharm Sci 10:1-16

Ahmed S, Ikram S (2016) Chitosan based scaffolds and their applications in wound healing. Achievem Life Sci 10:27-37. https://doi.org/10.1016/j.als.2016.04.001

Ahmed S, Ikram S (eds) (2017) Chitosan - derivatives, composites and applications. Beverly: Scrivener Publishing LLC, Wiley., 516 p. ISBN: 978-1-119-36350-7

Ahmed S, Annu AA, Sheikh J (2018) A review on chitosan centred scaffolds and their applications in tissue engineering. Int J Biol Macromol 116:849-862. https://doi.org/10.1016/j. ijbiomac.2018.04.176

Ahsan SM, Thomas M, Reddy KK, Sooraparaju SG, Asthana A, Bhatnagar I (2018) Chitosan as biomaterial in drug delivery and tissue engineering. Int J Biol Macromolecules 110:97-109. https://doi.org/10.1016/j.ijbiomac.2017.08.140

Akbar A, Shakeel A (2018) A review on chitosan and its nanocomposites in drug delivery. Int J Biol Macromolecules 109:273-286. https://doi.org/10.1016/j.ijbiomac.2017.12.078

Alaba PA, Oladoja NA, Sani YM, Ayodele OB, Mohammed IY, Olupinla SF, Daud WMW (2018) Insight into wastewater decontamination using polymeric adsorbents. J Environ Chem Eng 6:1651-1672. https://doi.org/10.1016/j.jece.2018.02.019

Ali A, Ahmed S (2018) A review on chitosan and its nanocomposites in drug delivery. Int J Biol Macromol 109:273-286. https://doi.org/10.1016/j.ijbiomac.2017.12.078

Alishahi A (2012) Chapter 15: Chitosan: a bioactive polysaccharide in marine-based foods. In: Karunaratne DN (ed) The complex world of polysaccharides, Croatia. InTech, Rijeka, pp 409428. https://doi.org/10.5772/48199

Alishahi A, Aïder M (2012) Applications of chitosan in the seafood industry and aquaculture: a review. Food Bioprocess Technol 5:817-830. https://doi.org/10.1007/s11947-011-0664-x

Aljawish A, Chevalot I, Jasniewski J, Scher J (2015) Enzymatic synthesis of chitosan derivatives and their potential applications. J Mol Catalysis B Enzymatic 112:25-39. https://doi. org/10.1016/j.molcatb.2014.10.014

Aljohani W, Ullah MW, Zhang XL, Yang G (2018) Bioprinting and its applications in tissue engineering and regenerative medicine. Int J Biol Macromol 107:261-275. https://doi. org/10.1016/j.ijbiomac.2017.08.171

Allan GG, Altman LC, Bensinger RE, Ghosh DK, Hirabayashi Y, Neogi AN, Neogi S (1984) Biomedical application of chitin and chitosan. In: Zikakis JP (ed) Chitin, chitosan, and related enzymes, part II. Academic, Orlando, pp 119-133. https://doi.org/10.1016/ B978-0-12-780950-2.50013-7

Al-Naamani L, Dobretsov S, Dutta J, Burgess JG (2017) Chitosan-zinc oxide nanocomposite coatings for the prevention of marine biofouling. Chemosphere 168:408-417. https://doi. org/10.1016/j.chemosphere.2016.10.033

Alves NM, Mano JF (2008) Chitosan derivatives obtained by chemical modifications for biomedical and environmental applications. Int J Biol Macromolecules 43:401-414. https://doi. org/10.1016/j.ijbiomac.2008.09.007

Amber Jennings J, Bumgardner JD (eds) (2017a) Chitosan based biomaterials. Volume 1: fundamentals. Woodhead Publishing Series in Biomaterials, vol 122. Elsevier, Kidlington, 342 p. ISBN: 978-0-08-100230-8. https://doi.org/10.1016/C2014-0-03147-4 
Amber Jennings J, Bumgardner JD (eds) (2017b) Chitosan based biomaterials. Volume 2: tissue engineering and therapeutics. Woodhead Publishing Series in Biomaterials, number 123. Elsevier, Kidlington, 296 p. ISBN: 978-0-08-100228-5. https://doi.org/10.1016/ C2014-0-03150-4

Aminabhavi TM, Dharupaneedi SP (2017) Production of chitosan-based hydrogels for biomedical applications. In: Amber Jennings J, Bumgardner JD (eds) Chitosan based biomaterials. Volume 1: fundamentals. Woodhead Publishing series in biomaterials, vol 122, part III, chapter 12. Elsevier, Kidlington, pp 295-319. https://doi.org/10.1016/B978-0-08-100230-8.00012-1

Anitha A, Sowmya S, Sudheesh Kumar PT, Deepthi S, Chennazhi KP, Ehrlich H, Tsurkan M, Jayakumar R (2014) Chitosan - a versatile semi-synthetic polymer in biomedical applications. Prog Polym Sci 39:1644-1667. https://doi.org/10.1016/j.progpolymsci.2014.02.008

Annu, Ahmed S, Ahmed S, Ikram S (2017) Chitin and chitosan: history, composition and properties. In: Ahmed S, Ikram S (eds) Chitosan - derivatives, composites and applications, section I, chapter 1. Scrivener Publishing LLC, Wiley, Beverly. https://doi.org/10.1002/9781119364849. ch1

Anraku M, Gebicki JM, Iohara D, Tomida H, Uekama K, Maruyama T, Hirayama F, Otagiri M (2018) Antioxidant activities of chitosans and its derivatives in in vitro and in vivo studies. Carbohydr Polym 199:141-149. https://doi.org/10.1016/j.carbpol.2018.07.016

Arbia W, Arbia L, Adour L, Amrane A (2013) Chitin extraction from crustacean shells using biological methods - a review. Food Technol Biotechnol 51:15-25

Arfin T (2017) Chapter 5: Chitosan and its derivatives: Overview of commercial applications in diverse fields. In: Ahmed S, Ikram S (eds) Chitosan - derivatives, composites and applications. Scrivener Publishing LLC, Wiley, pp 115-150. https://doi.org/10.1002/9781119364849.ch5

Argüelles-Monal W, Recillas-Mota M, Fernández-Quiroz D (2017) Chapter 13: Chitosan-based thermosensitive materials. In: Shalaby EA (ed) Biological activities and application of marine polysaccharides. InTech, Rijeka, pp 279-301. https://doi.org/10.5772/65713

Argüelles-Monal WM, Lizardi-Mendoza J, Fernandez-Quiroz D, Recillas-Mota MT, MontielHerrera M (2018) Chitosan derivatives: introducing new functionalities with a controlled molecular architecture for innovative materials. Polymers 10:342. https://doi.org/10.3390/ polym 10030342

Austin PR (1984) Chitin solvents and solubility parameters. In: Zikakis JP (ed) Chitin, chitosan, and related enzymes, part IV. Academic, Orlando, pp 227-238. https://doi.org/10.1016/ B978-0-12-780950-2.50020-4

Azarova YA, Pestov AV, Bratskaya SZ (2016) Application of chitosan and its derivatives for solidphase extraction of metal and metalloid ions: a mini-review. Cellulose 23:2273-2289. https:// doi.org/10.1007/s10570-016-0962-6

Azuma K, Izumi R, Osaki T, Ifuku S, Morimoto M, Saimoto H, Minami S, Okamoto (2015) Chitin, chitosan and its derivatives for wound healing: old and new materials. J Funct Biomater 6:104-142. DOI: https://doi.org/10.3390/jfb6010104

Badawy MEI, Rabea EI (2016) Chapter 7: Chitosan and its derivatives as active ingredients against plant pests and diseases. In: Chitosan in the preservation of agricultural commodities, pp 179216. https://doi.org/10.1016/B978-0-12-802735-6.00007-0

Badawy MEI, Rabea EI (2017) Chapter 1: Chitosan and its modifications as biologically active compounds in different applications. In: Masuell M, Renard D (eds) Advances in physicochemical properties of biopolymers. Bentham e-Books. Bentham Science Publishers, Sharjah, pp 1-108. ISBN: 978-1-68108-545-6

Badwan AA, Rashid I, Omari MM, Daras FH (2015) Chitin and chitosan as direct compression excipients in pharmaceutical applications. Mar Drugs 13:1519-1547. https://doi.org/10.3390/ md13031519

Balagangadharan K, Dhivya S, Selvamurugan N (2017) Chitosan based nanofibers in bone tissue engineering. Int $\mathrm{J}$ Biol Macromol 104:1372-1382. https://doi.org/10.1016/j. ijbiomac.2016.12.046

Balan V, Verestiuc L (2014) Strategies to improve chitosan hemocompatibility: a review. Eur Polym J 53:171-188. https://doi.org/10.1016/j.eurpolymj.2014.01.033 
Banerjee I, Pangule RC, Kane RS (2011) Antifouling coatings: recent developments in the design of surfaces that prevent fouling by proteins, bacteria, and marine organisms. Adv Mater 23:690-718. https://doi.org/10.1002/adma.201001215

Bano I, Arshad M, Yasin T, Ghauri MA, Younus M (2017) Chitosan: a potential biopolymer for wound management. Int J Biol Macromolecules 102:380-383. https://doi.org/10.1016/j. ijbiomac.2017.04.047

Baranwal A, Kumar A, Priyadharshini A, Oggu GS, Bhatnagar I, Srivastava A, Chandra P (2018) Chitosan: an undisputed bio-fabrication material for tissue engineering and bio-sensing applications. Int J Biol Macromol 110:110-123. https://doi.org/10.1016/j.ijbiomac.2018.01.006

Barbosa MA, Granja PL, Barrias CC, Amaral IF (2005) Polysaccharides as scaffolds for bone regeneration. ITBM RBM 26:212-217. https://doi.org/10.1016/j.rbmret.2005.04.006

Barbusiński K, Salwiczek S, Paszewska A (2016) The use of chitosan for removing selected pollutants from water and wastewater - short review. Architecture Civil Eng Environ 9:107-115

Bautista-Baños S, Romanazzi G, Jiménez-Aparicio A (eds) (2016) Chitosan in the preservation of agricultural commodities. Oxford: Academic Press, Elsevier Inc., 384 p. ISBN: 9780128027578

Bégin A, Dupuis I, Dufaux M, Leroux G (2004) Chapter 14: Use of chitosan for storage of mangoes. In: Shahidi F, Simpson BK (eds) Seafood quality and safety, Advances in the new millennium. ScienceTech Publishing Company, Canada, pp 187-194. ISBN: 0-9683220-2-6

Berezina N (2016) Chapter 3: Production and application of chitin. In: Luque R, Xu CP (eds) Biomaterials. Biological production of fuels and chemicals. De Gruyter, Berlin, pp 61-72. https://doi.org/10.1515/9783110342420-004

Berger J, Reist M, Mayer JM, Felt O, Peppas NA, Gurny R (2004a) Structure and interactions in covalently and ionically crosslinked chitosan hydrogels for biomedical applications. Eur J Pharm Biopharm 57:19-34. https://doi.org/10.1016/S0939-6411(03)00161-9

Berger J, Reist M, Mayer JM, Felt O, Gurny R (2004b) Structure and interactions in chitosan hydrogels formed by complexation or aggregation for biomedical applications. Eur J Pharm Biopharm 57:35-52. https://doi.org/10.1016/S0939-6411(03)00160-7

Bernardi F, Zadinelo IW, Alves HJ, Meurer F, dos Santos LD (2018) Chitins and chitosans for the removal of total ammonic of aquaculture effluents. Aquaculture 483:203-212. https://doi. org/10.1016/j.aquaculture.2017.10.027

Bernkop-Schnürch A, Dünnhaupt S (2012) Chitosan-based drug delivery. Eur J Pharm Biopharm 81:463-469. https://doi.org/10.1016/j.ejpb.2012.04.007

Bhatnagar A, Sillanpää M (2009) Applications of chitin- and chitosan-derivatives for the detoxification of water and wastewater - a short review. Adv Colloid Int Sci 152:26-38. https://doi. org/10.1016/j.cis.2009.09.003

Boamah PO, Huang Y, Hua MQ, Zhang Q, Wu JB, Onumah J, Sam-Amoah LK, Boamah PO (2015) Sorption of heavy metal ions onto carboxylate chitosan derivatives - a mini-review. Ecotoxicol Environ Safety 116:113-120. https://doi.org/10.1016/j.ecoenv.2015.01.012

Bodnar M, Hartmann JF, Borbely J (2005) Preparation and characterization of chitosan-based nanoparticles. Biomacromolecules 6:2521-2527. https://doi.org/10.1021/bm0502258

Bonecco MB, Martínez Sáenz MG, Buffa LM (2017) Chapter 4: Chitosan, from residue to industry. In: Masuell M, Renard D (eds) Advances in physicochemical properties of biopolymers. Bentham e-Books. Bentham Science Publishers, Sharjah, pp 224-256. ISBN: 978-1-68108-545-6

Borgogna M, Bellich B, Cesaro A (2011) Marine polysaccharides in microencapsulation and application to aquaculture: from sea to sea. Mar Drugs 9:2572-2604. https://doi.org/10.3390/ md9122572

Bornet A, Teissedre PL (2005) Applications and interest of chitin, chitosan and their derivatives in enology. J Int Sci Vigne Vin 39:199-207

Bornet A, Teissedre PL (2011) Chapter 36: Chitin, chitosan, and their derivatives in beverage industry. In: Kim SK (ed) Chitin, chitosan, oligosaccharides and their derivatives: biological activities and applications. CRC Press/Taylor \& Francis Group LLC, Boca Raton, pp 519-530. eBook ISBN: 9781439816042 
Bouligand Y (1965) Sur une architecture torsadée répandue dans de nombreuses cuticules d'Arthropodes. Compte Rendus Acad Sci Paris D 261:4864-4867

Braconnot H (1811) Recherches analytiques sur la nature des champignons. Annales de Chimie. Recueil de Mémoires concernant la chimie et les arts qui en dépendent et spécialement la pharmacie. 31 juillet 1811, tome soixante-dix-neuf. Klostermann J (ed) Librairie des Ecoles Impériales Polytechnique et des Ponts et Chaussées, Paris, pp 265-304

Braconnot H (1813) Nouvelles recherches analytiques sur la nature des champignons, pour servir de suite à celles qui ont été insérés dans les tomes LXXIX et LXXX des annales de chimie. Ann Chim 87:237-270

Brimacombe JS, Webber JM (1964) Mucopolysaccharides chemical structure, distribution and isolation, vol 6. BBA Library, Elsevier, Amsterdam, pp 18-42

Brück WM, Slater JW, Carney BF (2011) Chapter 2: Chitin and chitosan from marine organisms. In: Kim SK (ed) Chitin, chitosan, oligosaccharides and their derivatives: biological activities and applications. CRC Press/Taylor \& Francis Group LLC, Boca Raton, pp 11-24. eBook ISBN: 9781439816042

Cagri A, Ustunol Z, Ryser ET (2004) Antimicrobial edible films coatings. J Food Protection 67:833-8448

Canh LT, Lacroix M, Szabo PI, Mateescu MA (2004) Chapter 19: Chitosan modifications for pharmaceutical applications. In: Shahidi F, Simpson BK (eds) Seafood quality and safety. Advances in the new millennium. ScienceTech Publishing Company, Canada, pp 251-258

Carneiro J, Tedim J, Ferreira MGS (2015) Chitosan as a smart coating for corrosion protection of aluminum alloy 2024: a review. Prog Org Coatings 89:348-356. https://doi.org/10.1016/j. porgcoat.2015.03.008

Cerezuela R, Mesequer J, Angeles Esteban M (2011) Current knowledge in symbiotic use for fish aquaculture: a review. J Aquac Res Development S1:008. DOI: https://doi. org/10.4172/2155-9546

Chalongsuk R, Sribundit N (2013) Usage of chitosan in Thai pharmaceutical and cosmetic industries. Silpakorn U Sci Tech J 7:49-53

Chatterjee S, Chatterjee S, Chatterjee BP, Guha AK (2004) Clarification of fruit juice with chitosan. Process Biochem 39:2229-2232. https://doi.org/10.1016/j.procbio.2003.11.024

Cheba BA (2011) Chitin and chitosan: marine biopolymers with unique properties and versatile applications. Global J Biotechnol Biochem 6:149-153

Children JG (1824) Memoir on the chemical composition of the corneous parts of insects; by Augustus Odier. Translated from the original French, with some additional remarks and experiments. Bell T, Children JG, Sowerby JDC, Sowerby GB (eds) London, Zool J, volume 1, n I, march, 1824, article XV, pp 104-115

Choi C, Nam JP, Nah JW (2016) Application of chitosan and chitosan derivatives as biomaterials. J Ind Eng Chem 33:1-10. https://doi.org/10.1016/j.jiec.2015.10.028

Chung YC (2006) Improvement of aquaculture wastewater using chitosan of different degrees of deacetylation. Environ Technol 27:1199-1208

Chung YC, Li YH, Chen CC (2005) Pollutant removal from aquaculture wastewater using the biopolymer chitosan at different molecular weights. J Environ Sci Health A Tox Hazard Subst Environ Eng 40:1755-1790

Clark GL, Smith AF (1936) X-ray diffraction studies of chitin, chitosan and derivatives. J Phys Chem 40:863-879. https://doi.org/10.1021/j150376a001

Coma V (2012) Chapter 5: Recent developments in chitin and chitosan bio-based materials used for food preservation. In: Habibi Y, Lucia A (eds) Polysaccharide building blocks: a sustainable approach to the development of renewable biomaterials. Wiley, HobokenInc, pp 143-176. https://doi.org/10.1002/9781118229484.ch5

Costa R, Santos L (2017) Delivery systems for cosmetics - from manufacturing to the skin of natural antioxidants. Powder Technol 322:402-416. https://doi.org/10.1016/j.powtec.2017.07.086

Crini G (2005) Recent developments in polysaccharide-based materials used as adsorbents in wastewater treatment. Prog Polym Sci 30:38-70. https://doi.org/10.1016/j.progpolymsci.2004.11.002 
Crini G (2006) Non-conventional low-cost adsorbents for dye removal. Bioresour Technol 97:1061-1085. https://doi.org/10.1016/j.biortech.2005.05.001

Crini G (2015) Non-conventional adsorbents for dye removal. In: Sharma SK (ed) Green chemistry for dyes removal from wastewater. Scrivener Publishing LLC, Beverly, pp 359-407

Crini G, Badot PM (2008) Application of chitosan, a natural aminopolysaccharide, for dye removal from aqueous solutions by adsorption processes using batch studies: a review of recent literature. Prog Polym Sci 33:399-447. https://doi.org/10.1016/j.progpolymsci.2007.11.001

Crini G, Badot PM, Guibal E (eds) (2009) Chitine et chitosane - du biopolymère à l'application. Besançon, PUFC, p 303

Crini G, Morin-Crini N, Fatin-Rouge N, Déon S, Fievet P (2017) Metal removal from aqueous media by polymer-assisted ultrafiltration with chitosan. Arab J Chem 10:S3826-S3839. https:// doi.org/10.1016/j.arabjc.2014.05.020

Croisier F, Jérôme C (2013) Chitosan-based biomaterials for tissue engineering. Eur Polym J 49:780-792. https://doi.org/10.1016/j.eurpolymj.2012.12.009

Czechowska-Biskup R, Jarosińska D, Rokita B, Ulański P, Rosiak J (2012) Determination of degree of deacetylation of chitosan - comparison of methods. Progress on chemistry and application of chitin, vol XVII, pp 5-20

Dash M, Piras AM, Chiellini F (2009) Chitosan-based beads for controlled release of proteins. In: Barbucci R (ed) Hydrogels. Biological properties and applications. Springer, Milan, pp 111-120

Dash M, Chiellini F, Ottenbrite RM, Chiellini E (2011) Chitosan - a versatile semi-synthetic polymer in biomedical applications. Prog Polym Sci 36:981-1014. https://doi.org/10.1016/j. progpolymsci.2011.02.001

Dave D, Routray W (2018) Current scenario of Canadian fishery and corresponding underutilized species and fisheries byproducts: a potential source of omega-3 fatty acids. J Cleaner Product 180:617-641. https://doi.org/10.1016/j.jclepro.2018.01.091

Davis SP (ed) (2011) Chitosan: Manufacture, properties, and usage. Biotechnology in agriculture, industry and medicine. New York: Nova Science Publishers, Inc., 507 p. ISBN: 9781617288319

de Alvarenga ES (2011) Chapter 5: Characterization and properties of chitosan. In: Elnashar M (ed) Biotechnology of biopolymers. InTech, Rijeka, pp 91-108. https://doi.org/10.5772/17020

de Andrade JR, Oliveira MF, da Silva MGC, Vieira MGA (2018) Adsorption of pharmaceuticals from water and wastewater using nonconventional low-cost materials: a review. Ind Eng Chem Res 57:3103-3127. https://doi.org/10.1021/acs.iecr.7b05137

de Lima Batista AC, de Souza Neto FE, Paiva WD (2018) Review of fungal chitosan: past, present and perspectives in Brazil. Polimeros Cienca e Technologia 28:275-283. https://doi. org/10.1590/0104-1428.08316

De Mori A, Fernandez MP, Blunn G, Tozzi G, Roldo M (2018) 3D printing and electrospinning of composite hydrogels for cartilage and bone tissue engineering. Polymers 10:285. https://doi. org/10.3390/polym10030285

Desbrières J, Guibal E (2018) Chitosan for wastewater treatment. Polym Int 67:7-14. https://doi. org/10.1002/pi.5464

Desbrières J, Bousquet C, Babak V (2010) Surfactant-chitosan interactions and application to emulsion stabilization. Cellulose Chem Technol 44:395-406

Dima JB, Sequeiros C, Zaritzky N (2017) Chapter 3: Chitosan from marine crustaceans: production, characterization and applications. In: Shalaby EA (ed) Biological activities and application of marine polysaccharides. InTech, Rijeka, pp 39-56. https://doi.org/10.5772/65258

Dimassi S, Tabary N, Chai F, Blanchemain N, Martel B (2018) Sulfonated and sulfated chitosan for biomedical applications: a review. Carbohydr Polym 202:382-396. https://doi.org/10.1016/j. carbpol.2018.09.011

Ding FY, Li HB, Du YM, Shi XW (2018) Recent advances in chitosan-based self-healing materials. Res Chem Intermed 44:4827-4840. https://doi.org/10.1007/s11164-018-3339-7

Divya K, Jisha MS (2018) Chitosan nanoparticles preparation and applications. Environ Chem Lett 16:101-112. https://doi.org/10.1007/s10311-017-0670-y 
Dodane V, Vilivalam VD (1998) Pharmaceutical applications of chitosan. PSTT Pharm Sci Technol Today (6):246-253

Domard A, Domard M (2001) Chitosan: Structure-properties relationship and biomedical applications. In: Severian D (ed) Polymeric biomaterials. Marcel Dekker, New York, pp 187-212

Domingues RCC, Junior SBF, Silva RB, Cardoso VL, Reis MHM (2012) Clarification of passion fruit juice with chitosan: effects of coagulation process variables and comparison with centrifugation and enzymatic treatments. Process Biochem 47:467-471. https://doi.org/10.1016/j. procbio.2011.12.002

Dos Santos ZM, Caroni AL, Pereira MR, Da Silva DR, Fonseca JL (2009) Determination of deacetylation degree of chitosan: a comparison between conductometric titration and CHN elemental analysis. Carbohydr Res 344:2591-2595. https://doi.org/10.1016/j.carres.2009.08.030

Drewnowska O, Turek B, Cartanjen B, Gajewski (2013) Chitosan - a promising biomaterial in veterinary medicine. Polish J Veterinary Sci 16:843-848. https://doi.org/10.2478/pjvs-2013-0119

Dumitriu S (ed) (2001) Chapter 1: Polysaccharides as biomaterials. In: Polymeric biomaterials, Marcel Dekker, Inc, Basel, pp 1-62

Dutta PK (ed) (2016) Chitin and chitosan for regenerative medicine. Springer series on polymer and composite materials, Springer India, $389 \mathrm{p}$

Dutta J, Dutta PK (2011) Chapter 15: Antimicrobial activity of chitin, chitosan, and their oligosaccharides. In: Kim SK (ed) Chitin, chitosan, oligosaccharides and their derivatives: biological activities and applications. CRC Press/Taylor \& Francis Group LLC, Boca Raton, pp 195-214. eBook ISBN: 9781439816042

Dutta PK, Dutta J, Tripathi VS (2004) Chitin and chitosan: chemistry, properties and applications. J Sci Ind Res 63:20-31

Dutta PK, Rinki K, Dutta J (2011) Chitosan: a promising biomaterial for tissue engineering scaffolds. In: Jayakumar R, Prabaharan M, Muzzarelli RAA (eds) Chitosan for biomaterials II, Advances in polymer science 244. Springer, Berlin, pp 45-80

El Hadrami A, Adam LR, El Hadrami I, Daayf F (2010) Chitosan in plant protection. Mar Drugs 8:968-987. https://doi.org/10.3390/md8040968

El Halah A, López-Carrasquero F, Contreras J (2018) Applications of hydrogels in the adsorption of metallic ions. Revista Ciencia e Ingenieria 39:57-70

El Knidri H, Belaabed R, Addaou A, Laajeb A, Lahsini A (2018) Extraction, chemical modification and characterization of chitin and chitosan. Int J Biol Macromol 120:1181-1189. https:// doi.org/10.1016/j.ijbiomac.2018.08.139

Elder SH, Nettles DL, Bumgardner JD (2004) Chapter 4: Synthesis and characterization of chitosan scaffolds for cartilage-tissue engineering. In: Hollander AP, Hatton PV (eds) Biopolymer methods in tissue engineering. Methods in molecular biology, vol 238. Humana Press, Totowa, pp 41-48

Elieh-Ali-Komi D, Hamblin MR (2016) Chitin and chitosan: production and application of versatile biomedical nanomaterials. Int J Adv Res 4:411-427

El-Kamel A, Sokar M, Naggar V, Al Gamal S (2002) Chitosan and sodium alginate-based bioadhesive vaginal tablets. AAPS J 4:224-230

Elkassas D, Arafa A (2017) The innovative applications of therapeutic nanostructures in dentistry. Nanomedicine 13:1543-1562. https://doi.org/10.1016/j.nano.2017.01.018

Ellis CE, Korbutt GS (2017) Chitosan-based biomaterials for treatment of diabetes. In: Amber Jennings J, Bumgardner JD (eds) Chitosan based biomaterials. Volume 2: tissue engineering and therapeutics. Woodhead Publishing series in biomaterials, vol 123, part II, chapter 4. Elsevier, Kidlington, pp 91-113. https://doi.org/10.1016/B978-0-08-100228-5.00004-3

Elsabee MZ, Abdou ES (2013) Chitosan based edible films and coatings: a review. Mat Sci Eng C 33:1819-1841. https://doi.org/10.1016/j.msec.2013.01.010

Elsabee MZ, Morsi RE, Al-Sabagh AM (2009) Surface actvities properties of chitosan and its derivatives. Colloids Surfs B Biointerf 74:1-16. https://doi.org/10.1016/j.colsurfb.2009.06021

Elwakeel KZ (2010) Environmental application of chitosan resins for the treatment of water and wastewater: a review. J Dispers Sci Technol 31:273-288. https://doi. org/10.1080/01932690903167178 
Enescu D (2008) Use of chitosan in surface modification of textile materials. Roumanian Biotechnol Lett 13:4037-4048

Estevinho BN, Rocha F, Santos L, Alves A (2013) Microencapsulation with chitosan by spray drying for industry applications - a review. Trends Food Sci Technol 31:138-155. https://doi. org/10.1016/j.tifs.2013.04.001

Farea M, Halim AS, Omar NS (2014) Current scenario and future prospects of chitosan in dentistry. In: Kim SK (ed) Chitin and chitosan derivatives. Advances in drug discovery and developments, part III, chapter 23. CRC Press/Taylor \& Francis Group LLC, Boca Raton, pp 439-450

Farion IA, Burdukovskii VF, Kholkhoev BC, Timashev PS, Chailakhyan RK (2018) Functionalization of chitosan with carboxylic acids and derivatives of them: synthesis issues and prospects of practical use: a review. Express Polym Lett 12:1081-1105. https://doi. org/10.3144/expresspolymlett.2018.95

Felt O, Nuri P, Gurny R (1998) Chitosan: a unique polysaccharide for drug delivery. Drug Dev Ind Pharm 24:979-993. https://doi.org/10.3109/03639049809089942

Ferguson AN, O’Neill AG (2011) Focus on chitosan research. Nova Science Publishers, New York, $477 \mathrm{p}$

Fernandez-Saiz P (2012) Chapter 4: Chitosan and chitosan blends as antimicrobials. In: Lagaron JM, Ocio MJ, Lopez-Rubion A (eds) Antimicrobial polymers. Wiley, Hoboken. https://doi. org/10.1002/9781118150887.ch4

Fernandez-Saiz P, Ocio MJ, Lagaron JM (2010) The use chitosan in microbial films for food protection. In: Reviews: perspectives in agriculture, veterinary science, nutrition and natural resources, vol 5, pp 1-11. https://doi.org/10.1079/PAVSNNR20105024

Ferraro V, Cruz IB, Jorge RF, Malcata FX, Pintado ME, Castro PML (2010) Valorisation of natural extracts from marine source focused on marine by-products: a review. Food Res Int 43:22212233. https://doi.org/10.1016/j.foodres.2010.07.034

Focher B, Naggi A, Torri G, Cosani A, Terbojevich M (1992) Structural differences between chitin polymorphs and their precipitates from solutions - evidence from CP-MAS ${ }^{13} \mathrm{C}-\mathrm{NMR}$, FT-IR and FT-Raman spectroscopy. Carbohydr Polym 17:97-102

Francesko A, Díaz González M, Lozano GR, Tzanov T (2010) Chapter 12: Developments in the processing of chitin, chitosan and bacterial cellulose for textile and other applications. Advances in textile biotechnology. A volume in Woodhead Publishing series in textiles. Elsevier, pp 288-311. https://doi.org/10.1533/9780857090232.2.288

Francis Suh JK, Matthew HWT (2000) Application of chitosan-based polysaccharide biomaterials in cartilage tissue engineering: a review. Biomaterials 21:2589-2598

Friedman M, Juneja VK (2010) Review of antimicrobial and antioxidative activities of chitosans in food. J Food Prot 73:1737-1761

Galiano F, Briceno K, Marino T, Molino A, Christensen KV, Figoli A (2018) Advances in biopolymer-based membrane preparation and applications. J Membrane Sci 564:562-586. https://doi.org/10.1016/j.memsci.2018.07.059

Gallo M, Naviglio D, Caruso AA, Ferrara L (2016) Chapter 13: Applications of chitosan as a functional food. In: Novel approaches of nanotechnology in food, vol 1, pp 425-464. https:// doi.org/10.1016/B978-0-12-804308-0.00013-3

Gassara F, Antzak C, Ajila CM, Sarma SJ, Brar SK, Verma M (2015) Chitin and chitosan as natural flocculants for beer clarification. J Food Eng 166:80-85. https://doi.org/10.1016/j. jfoodeng.2015.05.028

Gerdts V, Mutwiri G, Richards J, Hurk SVDLVD, Potter AA (2013) Carrier molecules for use in veterinary vaccines. Vaccine 31:596-602. https://doi.org/10.1016/j.vaccine.2012.11.067

Gérente C, Lee VKC, Le Cloirec P, McKay G (2007) Application of chitosan for the removal of metals from wastewaters by adsorption - mechanisms and models review. Critical Rev Environ Sci Technol 37:41-127. https://doi.org/10.1080/10643380600729089

Gilson E (1894) Recherches chimiques sur la membrane cellulaire des champignons. Bull Soc Chim France 3:1099-1102

Gilson E (1895) Das chitin und die membranen der pilzzellen. Ber Dtsch Chem Ges 28:821-822. https://doi.org/10.1002/cber.189502801185 
Giri Dev VR, Neelakandan R, Sudha S, Shamugasundram OL, Nadaraj RN (2005) Chitosan - a polymer with wider applications. Text Mag 46:83.86

Goosen MFA (ed) (1997) Applications of chitin and chitosan. CRC Press LLC, Boca Raton. 336 p

Gortari MC, Hours RA (2013) Biotechnological processes for chitin recovery out of crustacean waste: a mini-review. Electron J Biotechnol 16:1-18. https://doi.org/10.2225/ vol16-issue3-fulltext-10

Goy RC, De Britto D, Assis OB (2009) A review of the antimicrobial activity of chitosan. Polímeros 19:241-247. https://doi.org/10.1590/S0104-14282009000300013

Grande-Tovar CD, Chaves-Lopez C, Serio A, Rossi C, Paparella A (2018) Chitosan coatings enriched with essential oils: effects on fungi involved in fruit decay and mechanisms of action. Trends Food Sci Technol 78:61-71. https://doi.org/10.1016/j.tifs.2018.05.019

Grifoll-Romero L, Pascual S, Aragunde H, Biarnes X, Planas A (2018) Chitin deacetylases: structures, specificities, and biotech applications. Polymers 10:352. https://doi.org/10.3390/ polym 10040352

Guibal E (2005) Heterogenous catalysis on chitosan-based materials: a review. Prog Polym Sci 30:71-109. https://doi.org/10.1016/j.progpolymsci.2004.12.001

Gunjal K, Teftal H, Simpson BK, Goldsmith P (2004) Chapter 20: Economics of chitin, chitosan and carotenoprotein production from shrimp waste. In: Shahidi F, Simpson BK (eds) Seafood quality and safety. Advances in the new millennium. ScienceTech Publishing Company, Canada, pp 259-274

Gutiérrez TJ (2017) Chapter 8: Chitosan applications in textile and food industry. In: Ahmed S, Ikram S (eds) Chitosan - derivatives, composites and applications. Scrivener Publishing LLC, Wiley, pp 185-232. https://doi.org/10.1002/9781119364849.ch8

Hadwiger LA (2017) Chitosan - molecular forms with potential in agriculture and medicine. J Drug Design Res 4:1036

Hamed I, Özogul F, Regenstein JM (2016) Industrial applications of crustacean by-products (chitin, chitosan, and chitooligosaccharides): a review. Trends Food Sci Technol 48:40-50. https:// doi.org/10.1016/j.tifs.2015.11.007

Hamedi H, Moradi S, Hudson SM, Tonelli AE (2018) Chitosan based hydrogels and their applications for drug delivery in wound dressings: a review. Carbohydr Polym 199:445-460. https:// doi.org/10.1016/j.carbpol.2018.06.114

Hamman JH (2010) Chitosan based polyelectrolyte complexes as potential carrier materials in drug delivery systems. Mar Drugs 8:1305-1322. https://doi.org/10.3390/md8041305

Han JW, Ruiz-Garcia L, Qian JP, Yang XT (2018) Food packaging: a comprehensive review and future trends. Comprehensive Rev Food Sci Food Safety 17:860-877. https://doi. org/10.1111/1541-4337.12343

Harikrishnan R, Kim JS, Balasundaram C, Heo MS (2012) Immunomodulatory effects of chitin and chitosan enriched diets in Epinephelus bruneus against Vibrio alginolyticus infection. Aquaculture 326(329):46-52. https://doi.org/10.1016/j.aquaculture.2011.11.034

Harish Prashanth KV, Tharanathan (2007) Chitin/chitosan: modifications and their unlimited application potential - an overview. Trends Food Sci Technol 18:117-131. https://doi.org/10.1016/j. tifs.2006.10.022

Harris M, Alexander C, Wells CM, Bumgardner JD (2017) Chitosan for the delivery of antibiotics. In: Amber Jennings J, Bumgardner JD (eds) Chitosan based biomaterials. Volume 2: tissue engineering and therapeutics. Woodhead Publishing series in biomaterials, vol 123, part III, chapter 6. Elsevier, Kidlington, pp 147-174

Hayashi Y (2011) Chapter 32: Applications of chitosan oligosaccharide and glucosamine in dentistry. In: Kim SK (ed) Chitin, chitosan, oligosaccharides and their derivatives: biological activities and applications. CRC Press, Taylor \& Francis Group LLC, Boca Raton, pp 447-460. eBook ISBN: 9781439816042

Hayashi Y, Yanagiguchi K, Koyama Z, Ikeda T, Yamada S (2013) Chapter 16: Chitosan application in dentistry. In: Kim SK (ed) Marine nutraceuticals. Prospects and perspectives. CRC Press, Taylor \& Francis Group, Boca Raton, pp 233-242. ISBN 9781138199965 
Hejazi R, Amiji M (2001) Chapter 10: Chitosan-based delivery systems: physicochemical properties and pharmaceutical applications. In: Dumitriu S (ed) Polymeric biomaterials. Marcel Dekker, Inc., Basel, pp 213-238. https://doi.org/10.1201/9780203904671.ch10

Heuser M, Cárdenas G (2014) Chitosan-copper paint types as antifouling. J Chil Chem Soc 59:2415-2419. https://doi.org/10.4067/S0717-97072014000200004

Heuser M, Rivera C, Nuñez C, Cárdenas G (2009) Chitosan-copper paint types as antifouling. J Chil Chem Soc 54:448-453. https://doi.org/10.4067/S0717-97072009000400028

Heux L, Brugnerotto J, Desbrières J, Versal MF, Rinaudo M (2000) Solid state NMR for determination of degree of acetylation of chitin and chitosan. Biomacromolecules 1:746-751. https:// doi.org/10.1021/bm000070y

Hirai A, Odani H, Nakajima A (1991) Determination of degree of deacetylation of chitosan by $1 \mathrm{H}$ NMR spectroscopy. Polym Bull 26:87-94. https://doi.org/10.1007/BF00299352

Hirano S (1997). Chapter 2: Applications of chitin and chitosan in the ecological and environmental fields. In: Goosen MFA (ed) Applications of chitin and chitosan. CRC Press LLC, Boca Raton, pp 31-56

Hon DNS (1996) Chitin and chitosan: Medical applications. In: Dumitriu S (ed) Polysaccharides in medicinal applications, part II, chapter 21. Marcel Dekker, Inc., New York, pp 631-651

Honarkar H, Barikani M (2009) Applications of biopolymers I: chitosan. Monatsh Chem 140:1403-1420. https://doi.org/10.1007/s00706-009-0197-4

Hoppe-Seyler F (1894) Ueber chitin and cellulose. Ber Dtsch Chem Ges 27:3329-3331

Horst MN, Walker AN, Klar E (1993) Chapter 4: The pathway of crustacean chitin synthesis. In: Horst MN and Freeman (eds) The crustacean integument - morphology and biochemistry. CRC Press, Boca Raton, pp 113-149

Hu Z, Zhang DY, Lu ST, Li PW, Li SD (2018) Chitosan-based composite materials for prospective hemostatic applications. Mar Drugs 16(8). https://doi.org/10.3390/md16080273

Huang J, Cheng ZH, Xie HH, Gong JY, Lou J, Ge Q, Wang YJ, Wu YF, Liu SW, Sun PL, Mao JW (2014) Effect of quaternization on physiochemical and biological activities of chitosan from squid pens. Int J Biol Macromol 70:545-550. https://doi.org/10.1016/j.ijbiomac.2014.07.017

Hudson SM, Smith C (1998). Chapter 4: Polysaccharides: chitin and chitosan. Chemistry and technology of their use as structural materials. In: Kaplan DL (ed) Biopolymers from renewable resources. Springer, Berlin, pp 96-118

Illum L (1998) Chitosan and its use as a pharmaceutical excipient. Pharm Res 15:1326-1331

Illum L, Davis SBS (2004) Chapter 27: Chitosan as delivery system for the transmucosal administration of drugs. In: Dumitriu S (ed) Polysaccharides. Structural diversity and functional versatility. Marcel Dekker, New York, pp 643-659

Ippólito SD, Mendieta JR, Terrile MC, Tonón CV, Mansilla AY, Colman S, Albertengo L, Rodríguez MS, Casalongué C (2017) Chapter 1: Chitosan as source for pesticide formulations. In: Shalaby EA (ed) biological activities and application of marine polysaccharides. InTech, Rijeka, pp 3-15. https://doi.org/10.5772/65588

Islam SU, Shahid M, Mohammad F (2013) Green chemistry approaches to develop antimicrobial textiles based on sustainable biopolymers - a review. Ind Eng Chem Res 52:5245-5260. https://doi.org/10.1021/ie30627x

Jalal Zohuriaan-Mehr M (2005) Advances in chitin and chitosan modification through graft copolymzerization: a comprehensive review. Iranian Polym J 14:235-265

Jana S, Gandhi A, Sen KK, Basu SK (2014) Biomedical applications of chitin and chitosan derivatives. In: Kim SK (ed) Chitin and chitosan derivatives. Advances in drug discovery and developments, part III, chapter 18. CRC Press/Taylor \& Francis Group LLC, Boca Raton, pp 337-360. ISBN 9781466566286

Jardine A, Sayed S (2018) Valorisation of chitinous biomass for antimicrobial applications. Pure Appl Chem 90:293-304. https://doi.org/10.1515/pac-2017-0707

Jayakumar R, Reis RL, Mano JF (2006) Chemistry and applications of phosphorylated chitin and chitosan. e-Polymers n 35, pp 1-16, ISSN 1618-7229

Jayakumar R, Nwe N, Tokura S, Tamura H (2007) Sulfated chitin and chitosan as novel biomaterials. Int J Biol Macromol 40:175-181. https://doi.org/10.1016/j.ijbiomac.2006.06.021 
Jayakumar R, Selvamurugan N, Nair SV, Tokura S, Tamura H (2008) Preparative methods of phosphorylated chitin and chitosan - an overview. Int J Biol Macromol 43:221-225. https:// doi.org/10.1016/j.ijbiomac.2008.07.004

Jayakumar R, Prabaharan M, Nair SV, Tamura H (2010a) Novel chitin and chitosan nanofibers in biomedical applications. Biotechnol Adv 28:142-150. https://doi.org/10.1016/j. biotechadv.2009.11.001

Jayakumar R, Menon D, Manzoor K, Nair SV, Tamura H (2010b) Biomedical applications of chitin and chitosan based nanomaterials - a short review. Carbohydr Polym 82:227-232. https:// doi.org/10.1016/j.carbpol.2010.04.074

Jayakumar R, Prabaharan M, Muzzarelli RAA (2011a) Chitosan for biomaterials I. In: Jayakumar R, Prabaharan M, Muzzarelli RAA (eds) Advances in polymer science volume 243. Springer. Berlin, $236 \mathrm{p}$

Jayakumar R, Prabaharan M, Muzzarelli RAA (eds) (2011b) Chitosan for biomaterials II. Advances in polymer science 244 . Springer, Berlin. $212 \mathrm{p}$

Je JY, Ahn CB (2011) Chapter 20: Antihypertensive actions of chitosan and its derivatives. In: Kim SK (ed) Chitin, chitosan, oligosaccharides and their derivatives: biological activities and applications. CRC Press/Taylor \& Francis Group LLC, Boca Raton, pp 263-270. eBook ISBN: 9781439816042

Je JY, Kim SK (2012) Chitosan as potential marine nutraceutical. In: Kim SK (ed) Marine medicinal foods: implications and applications - animals and microbes. Advances in food and nutrition research. vol 65, chapter 7. Academic, Oxford, pp 121-135. https://doi.org/10.1016/ B978-0-12-416003-3.00007-X

Je JY, Kim SK (2013) Chapter 18: Chitosan and its derivatives: potential use as nutraceuticals. In: Kim SK (ed) Marine nutraceuticals. Prospects and perspectives. CRC Press/Taylor \& Francis Group, Boca Raton, pp 257-266. ISBN 9781138199965

Jeuniaux C (1966) Chitinases. In: Neufeld EF, Ginsburg V (eds) methods in enzymology, vol VIII. Academic, New York, pp 644-650

Jiang X, Chen L, Zhong W (2003) A new linear potentiometric titration method for the determination of deacetylation degree of chitosan. Carbohydr Polym 54:457-463. https://doi. org/10.1016/j.carbpol.2003.05.004

Jimtaisong A, Saewan (2014) Utilization of carboxymethyl chitosan in cosmetics. Int J Cosmetic Sci 36:12-21

Jo GH, Park RD, Jung WJ (2011) Chapter 4: Enzymatic production of chitin from crustacean shell waste. In: Kim SK (ed) Chitin, chitosan, oligosaccharides and their derivatives: biological activities and applications. CRC Press/Taylor \& Francis Group LLC, Boca Raton, pp 37-45. eBook ISBN: 9781439816042

Junginer HE, Sadeghi AMM (2014) Synthesis, characterization, and biomedical applications of chitosan. In: Kim SK (ed Chitin and chitosan derivatives. Advances in drug discovery and developments, part I, chapter 2. CRC Press/Taylor \& Francis Group LLC, Boca Raton, pp 15-68. ISBN 9781466566286

Kang ML, Cho CS, Yoo HS (2009) Application of chitosan microspheres for nasal delivery of vaccines. Biotechnol Adv 27:857-865. https://doi.org/10.1016/j.biotechadv.2009.06.007

Karadeniz F, Kim SK (2014a) Antidiabetic applications of chitosan and its derivatives. In: Kim SK (ed) Chitin and chitosan derivatives. Advances in drug discovery and developments, part II, chapter 10. CRC Press/Taylor \& Francis Group LLC, Boca Raton, pp 191-200. ISBN 9781466566286

Karadeniz F, Kim SK (2014b) Antidiabetic applications of chitosan and its derivatives: a mini review. Adv Food Nutr Res 73:33-44. https://doi.org/10.1016/B978-0-12-800268-1.00003-2

Kardas I, Struszczyk MH, Kucharska M, van den Broek LAM, van DAM JEG, Ciechańska D (2012) Chitin and chitosan as functional biopolymers for industrial applications. In: Narvard P (ed) The European Polysaccharide Network of Excellence (EPNOE). Springer, Wien, pp 329373. https://doi.org/10.1007/978-3-7091-0421-7_11 
Karthik N, Binod P, Pandey A (2017) Chapter 15: Chitinases. In: Pandey A, Negi S, Soccol CR (eds) Current developments in biotechnology and bioengineering production, isolation and purification of industrial products. Elsevier, Amsterdam, pp 335-368

Kasaai MR (2008) A review of several reported procedures to determine the degree of $\mathrm{N}$-acetylation for chitin and chitosan using infrared spectroscopy. Carbohydr Polym 71:497-508. https://doi. org/10.1016/jcarbpol.2007.07.009

Kasaai MR (2009) Various methods for determination of the degree of $\mathrm{N}$-acetylation of chitin and chitosan: a review. J Agric Food Chem 57:1667-1676. https://doi.org/10.1021/jf803001m

Kasaai MR (2011) Chapter 12: The use of various type of NMR and IR spectroscopy for structural characterization of chitin and chitosan. In: Kim SK (ed) Chitin, chitosan, oligosaccharides and their derivatives: biological activities and applications. CRC Press/Taylor \& Francis Group LLC, Boca Raton, pp 149-170. eBook ISBN: 9781439816042

Katiyar D, Hemantaranjan A, Singh B, Bhanu N (2014) A future perspective in crop protection: Chitosan and its oligosaccharides. Adv Plants Agriculture Res 1:00006

Kato Y, Onishi H, Machida Y (2003) Application of chitin and chitosan derivatives in the pharmaceutical field. Current Pharm Biotechnol:303-309

Kaur S, Dhillon GS (2014) The versatile biopolymer chitosan: potential sources, evaluation of extraction methods and applications. Critical Rev Microbiol 40:155-175. https://doi.org/10.31 09/1040841X.2013.770385

Kaur S, Dhillon GC (2015) Recent trends in biological extraction of chitin from marine shell wastes: a review. Crit Rev Biotechnol 35:44-61. https://doi.org/10.3109/07388551.2013.798 256

Kean T, Thanou M (2010) Biodegradation, biodistribution and toxicity of chitosan. Adv Drug Deliv Rev 62:3-11. https://doi.org/10.1016/j.addr.209.09.004

Kean T, Thanou M (2011) Chapter 10: Chitin and chitosan: sources, production and medical applications. In: Williams PA (ed) Renewable resources for functional polymers and biomaterials. Polysaccharides, proteins and polyesters. RSC polymer chemistry series, RSC Publishing, Cambridge, pp 292-318

Kedjarune-Leggat U, Leggat PA (2011) Chapter 18: Chitosan and its modification: are they possible vehicles for gene therapy? In: Xubo Y (ed) Non-viral gene therapy. InTech Publisher, Rijeka, pp 439-454

Keegan GM, Smart JD, Ingram MJ, Barnes LM, Burnett GR, Rees GD (2012) Chitosan microparticles for the controlled delivery of fluoride. J Dentistry 40:229-240. https://doi.org/10.1016/j. jdent.2011.12.012

Khor E (2001) Chitin: fulfilling a biomaterials promise. Elsevier Ltd. 1st edn, 148 p. https://doi. org/10.1016/B978-008044018-7/50001-4

Khor E (2011) Chapter 30: Medical applications of chitin and chitosan: Going forward. In: Kim SK (ed) Chitin, chitosan, oligosaccharides and their derivatives: biological activities and applications. CRC Press/Taylor \& Francis Group LLC, Boca Raton, pp 405-413. eBook ISBN: 9781439816042

Khor E, Lim LY (2003) Implantable applications of chitin and chitosan. Biomaterials 24:23392349. https://doi.org/10.1016/S0142-9612(03)00026-7

Khor E, Wan ACA (2014) Chapter 1: Overview of chitin and chitosan research. In: Khor E, Wan ACA (eds) Chitin. Fulfilling a biomaterials promise. Elsevier, Oxford, pp 1-20

Khoushab F, Yamabhai M (2010) Chitin research revisited. Mar Drugs 8:1988-2012. https://doi. org/10.3390/md8071988

Kienzle-Sterzer C, Rodriguez-Sanchez D, Rha C (1984) Solution properties of chitosan: chain conformation. In: Zikakis JP (ed) Chitin, chitosan, and related enzymes, part V. Academic, Orlando, pp 383-396

Kim SK (ed) (2011) Chitin, chitosan, oligosaccharides and their derivatives: biological activities and applications. CRC Press/Taylor \& Francis Group LLC, Boca Raton, 666 p. eBook ISBN: 9781439816042

Kim SK (ed) (2014) Chitin and chitosan derivatives. Advances in drug discovery and developments. CRC Press/Taylor \& Francis Group LLC, Boca Raton, 511 p. ISBN 9781466566286 
Kim SK, Je JY (2011) Chapter 5: Continuous production of chitooligosaccharides by enzymatic hydrolysis. In: Kim SK (ed) Chitin, chitosan, oligosaccharides and their derivatives: biological activities and applications. CRC Press/Taylor \& Francis Group LLC, Boca Raton, pp 47-52. eBook ISBN: 9781439816042

Kim SK, Karadeniz F (2013) Chapter 16: Chitosan and its derivatives for treatment of diabetic complications. In: Kim SK (ed) Marine pharmacognosy. Trends and applications. CRC Press/ Taylor \& Francis Group, Boca Raton, pp 191-200. ISBN 9781439892299

Kim MM, Kim SK (2011) Chapter 16: Anti-inflammatory activity of chitin, chitosan, and their derivatives. In: Kim SK (ed) Chitin, chitosan, oligosaccharides and their derivatives: biological activities and applications. CRC Press/Taylor \& Francis Group LLC, Boca Raton, pp 215-223. eBook ISBN: 9781439816042

Kim SK, Pangestuti R (2013) Chapter 4: Chitosan-based biomaterials against diabetes and related complications. In: Kim SK (ed) Marine nutraceuticals. Prospects and perspectives. CRC Press/ Taylor \& Francis Group, Boca Raton, pp 33-44. ISBN 9781138199965

Kim SK, Venkatesan J (2014) Chitin and chitosan derivatives. In: Kim SK (ed) Chitin and chitosan derivatives. Advances in drug discovery and developments, part I, Chapter 1. CRC Press/Taylor \& Francis Group LLC, Boca Raton, pp 3-14. ISBN 9781466566286

Kim SK, Choi JH, Balmaceda EA, Rha CK (1999) Chitosan. In: Kühtreiber WM, Lanza RP, Chick WL (eds) Cell encapsulation technology and therapeutics, part II. Encapsulation systems, section 1, chapter 13. Birkhäuser, Boston, pp 151-172. ISBN 978-1-4612-1586-8

Kmiec M, Pighinelle L, Tedesco MF, Silva MM, Reis V (2017) Chitosan-properties and applications in dentistry. Adv Tissue Eng Regenerat Med 2:00035. https://doi.org/10.15406/ atroa.2017.02.00035

Knezevic-Jugovic Z, Petronijevic Z, Smelcerovic A (2011) Chapter 3: Chitin and chitosan from microorganisms. In: Kim SK (ed) Chitin, chitosan, oligosaccharides and their derivatives: biological activities and applications. CRC Press/Taylor \& Francis Group LLC, Boca Raton, pp 25-36. eBook ISBN: 9781439816042

Komi DEA, Sharma L, Dela Cruz CS (2018) Chitin and its effects on inflammatory and immune responses. Clin Rev Allergy Immunol 54:213-223. https://doi.org/10.1007/s12016-017-8600-0

Kos L (2016) Use of chitosan for textile wastewater decolourization. Fibres Text 24:130-135. https://doi.org/10.5604/12303666.1196623

Krajewska B (2005) Membrane-base processes performed with use of chitin/chitosan materials. Sep Purif Technol 41:305-312. https://doi.org/10.1016/j.seppur.2004.03.019

Krishnaswami V, Kandansamy R, Alagarsamy S, Palanisamy R, Natesan S (2018) Biological macromolecules for ophthalmic drug delivery to treat ocular diseases. Int J Biol Macromol 110:7-19. https://doi.org/10.1016/j.ijbiomac.2018.01.120

Kubota N, Shimoda K (2004) Chapter 29: Macromolecular complexes of chitosan. In: Dumitriu S (ed) Polysaccharides. Structural diversity and functional versatility. Marcel Dekker, New York, pp 679-705

Kumirska J, Weinhold MX, Czerwicka M, Kaczyński Z, Bychowska A, Brzozowski K, Thöming J, Stepnowski P (2011) Chapter 2: Influence of the chemical structure and physicochemical properties of chitin- and chitosan-based materials on their biomedical activity. In: Laskovski A (ed) Biomedical engineering, trends in materials science. InTech Publisher, Rijeka, pp 25-64

Kurita K (1986) Chemical modifications of chitin and chitosan. In: Muzzarelli R, Jeuniaux C, Gooday GW (eds) Chitin in nature and technology. Plenum Press, New York, pp 287-293. https://doi.org/10.1007/978-1-4613-2167-5_37

Kurita K (1998) Chemistry and application of chitin and chitosan. Polym Degrad Stab 59:117-120

Kurita K (2001) Controlled functionalization of the polysaccharide chitin. Prog Polym Sci 26:1921-1971

Kurita K (2006) Chitin and chitosan: functional biopolymers from marine crustaceans. Mar Biotechnol 8:203-226. https://doi.org/10.1007/s10126-005-0097-5

Kyzas GZ, Bikiaris DN, Mitropoulos AC (2017) Chitosan adsorbents for dye removal: a review. Polym Int 66:1800-1811. https://doi.org/10.1002/pi.5467 
Labrude P (1997) De quelques pharmaciens célèbres, aux noms sur des plaques de rues ou ignorées par elles, à Nancy et dans l'agglomération nancéienne. Bulletin des Académie et Société Lorraines des Sciences 36:171-181

Labrude P, Becq C (2003) Le pharmacien et chimiste Henri Braconnot. Rev Hist Pharm 337:61-78

Lakshmanan VK, Snima KS, Bumgardner JD, Nair SV, Jayakumar R (2011) Chitosan-based nanoparticles in cancer therapy. In: Jayakumar R, Prabaharan M, Muzzarelli RAA (eds) Chitosan for biomaterials I. Springer, Berlin. Adv Polym Sci 243:55-91

Lassaigne IL (1843) Sur les tissus tégumentaires des insectes de différents ordres. Compte Rendus des Séances de l'Académie des Sciences 16:1087-1089

Layek B, Singh J (2017) Chitosan for DNA and gene therapy. In: Amber Jennings J, Bumgardner JD (eds) Chitosan based biomaterials. Volume 2: tissue engineering and therapeutics. Woodhead Publishing series in biomaterials, vol 123, part III, chapter 8. Elsevier, Kidlington, pp 209-244. https://doi.org/10.1016/B978-0-08-100228-5.00008-0

Ledderhose G (1876) Über salzsäures glycosamin. Ber Dtch Chem Ges 9:1200-1201

Ledderhose G (1878) Über chitin und seine spaltungs produkte. Z Physiol Chem 2:213-227

Lee KY (2007) Chitosan and its derivatives for gene delivery. Macromol Res 15:195-201

Li Q, Dunn ET, Grandmaison, Goosen MFA (1997). Chapter 1: Applications and properties of chitosan. In: Goosen MFA (ed) Applications of chitin and chitosan. CRC Press LLC, Boca Raton, pp 3-30

Li CB, Hein S, Wang K (2008) Biosorption of chitin and chitosan. Mater Sci Technol 24:1088 1099. https://doi.org/10.1179/17438408X341771

Li HJ, Hu C, Yu HJ, Chen CZ (2018) Chitosan composite scaffolds for articular cartilage defect repair: a review. RSC Adv 8:3736-3749. https://doi.org/10.1039/c7ra11593h

Lian Z, Pan R, Wang J (2016) Microencapsulation of norfloxacin in chitosan/chitosan oligosaccharides and its application in shrimp culture. Int J Biol Macromol 92:587-592. https://doi. org/10.1016/j.ijbiomac.2016.07.074

Liang S, Sun Y, Dai X (2018) A review of the preparation, analysis and biological functions of chitooligosaccharide. Int J Mol Sci 19:2197. https://doi.org/10.3390/ijms19082197

Liaqat F, Eltem R (2018) Chitooligosaccharides and their biological activities: a comprehensive review. Carbohydr Polym 184:243-259. https://doi.org/10.1016/j.carbpol.2017.12.067

Lima EL, Muñoz LC, Harris RE, Caballaro AMH (2012). Chapter 24: Potential applications of chitosan as a marine cosmeceutical. In: Kim SK (ed) Marine cosmeceuticals. Trends and prospects. CRC Press/Taylor \& Francis Group LLC, Boca Raton, pp 319-335. ISBN 9781439860281

Liu C, Bai R (2014) Recent advances in chitosan and its derivatives as adsorbents for removal of pollutants from water and wastewater. Current Opinion Chem Eng 4:62-70. https://doi. org/10.1016/j.coche.2014.01.004

Liu X, Ma L, Mao Z, Gao C (2011) Chitosan-based biomaterials for tissue repair and regeneration. In: Jayakumar R, Prabaharan M, Muzzarelli RAA (eds) Chitosan for biomaterials II. Advances in polymer science 244 , Springer, Berlin, pp 81-127

Lizardi-Mendoza J, Argüelles Monal WM, Goycoolea Valencia FM (2016) Chapter 1: Chemical characteristics and functional properties of chitosan. In: Chitosan in the preservation of agricultural commodities, pp 3-31. https://doi.org/10.1016/B978-0-12-802735-6.00001-X

LogithKumar R, KeshavNarayan A, Dhivya S, Chawla A, Saravanan S, Selvamurugan N (2016) A review of chitosan and its derivatives in bone tissue engineering. Carbohydr Polym 151:172188. https://doi.org/10.1016/j.carbpol.2016.05.049

Lucio D, Martínez-Ohárriz MC (2017) Chapter 6: Chitosan: Strategies to increase and modulate drug release rate. In: Shalaby EA (ed) Biological activities and application of marine polysaccharides. InTech, Rijeka, pp 107-127. https://doi.org/10.5772/65714

Luna-Bárcenas G, Prokhorov E, Elizalde-Peña E, Nuno-Licona A, Sanchez IC, Gough JE, Velasquillo-Martinez C, Schmidt CE (2011) Chitosan-based hydrogels for tissue engineering applications. In: Series: biotechnology in agriculture, industry and medicine chemical Engineering methods and technology. Nova Science Publishers, New York

Macquarie DJ, Hardy JJE (2005) Applications of functionalized chitosan in catalysis. Ind Eng Chem Res 44:8499-8520 
Majekodunmi SO (2016) Current development of extraction, characterization and evaluation of properties of chitosan and its use in medicine and pharmaceutical industry. Am J Polym Sci 6:86-91. https://doi.org/10.5923/j.ajps.20160603.04

Maniukiewicz W (2011) Chapter 8: X-ray diffraction of chitin, chitosan, and their derivatives. In: Kim SK (ed) Chitin, chitosan, oligosaccharides and their derivatives: biological activities and applications. CRC Press/Taylor \& Francis Group LLC, Boca Raton, pp 83-94. eBook ISBN: 9781439816042

Marpu SB, Benton EN (2018) Shining light on chitosan: a review on the usage of chitosan for photonics and nanomaterials research. Int J Mol Sci 19:1795. https://doi.org/10.3390/ ijms 19061795

Mateescu MA, Ispas-Szabo P, Assad E (2015a) Chitosan and its derivatives as self-assembled systems for drug delivery. In: Mateescu MA, Ispas-Szabo P, Assad E (eds) Controlled drug delivery. The role of self-assembling multi-task excipients. Woodhead Publishing Series in Biomedicine, vol 74. Elsevier, Kidlington, pp 85-125

Mateescu MA, Ispas-Szabo P, Assad E (eds) (2015b) Chitosan-based polyelectrolyte complexes as pharmaceutical excipients. In: Controlled drug delivery. The role of self-assembling multitask excipients. Woodhead Publishing series in biomedicine, vol 74. Elsevier, Kidlington, pp 127-161

Mati-Baouche N, Elchinger PH, de Baynast H, Pierre G, Delattre C, Michaud P (2014) Chitosan as an adhesive. Eur Polym J 60:198-212. https://doi.org/10.1016/j.eurpolymj.2014.09.008

Meyer KH, Pankow GW (1935) Sur la constitution et la structure de la chitine. Helv Chim Acta 18:589-598. https://doi.org/10.1002/hlca.19350180177

Miranda Castro SP, Lizárraga Paulín EG (2012) Chapter 1: Is chitosan a new panacea? Areas of application. In: Karunaratne DN (ed) The complex world of polysaccharides. InTech, Croatia, Rijeka, pp 3-45. https://doi.org/10.5772/51200

Mohandas A, Deepthi S, Biswas R, Jayakumar R (2018) Chitosan based metallic nanocomposite scaffolds as antimicrobial wound dressings. Bioactive Mat 3:267-277. https://doi. org/10.1016/j.bioactmat.2017.11.003

Moratti SC, Cabral JD (2017) Antibacterial properties of chitosan In: Amber Jennings J, Bumgardner JD (eds) Chitosan based biomaterials. Volume 1: fundamentals. Woodhead Publishing series in biomaterials, vol 122, part I, chapter 2. Elsevier, Kidlington, pp 31-44. https://doi.org/10.1016/B978-0-08-100230-8.00002-9

Mourya VK, Inamdar NN (2008) Chitosan-modifications and applications: opportunities galore. React Funct Polym 68:1013-1051. https://doi.org/10.1016/j.reactfunctpolym.2008.03.002

Muñoz LC, Lima EL, Harris RE, Mengíbar MAL, Contreras NA, Caballero AMH (2012). Chapter 3: Chemical properties of chitosan as a marine cosmeceutical. In: Kim SK (ed) Marine cosmeceuticals. Trends and prospects. CRC Press/Taylor \& Francis Group LLC, Boca Raton, pp 39-50. ISBN 9781439860281

Muñoz-Bonilla A, Cerrada ML, Fernández-García M (eds) (2014) Chapter 2: Antimicrobial activity of chitosan in food, agriculture and biomedicine. In: Polymeric materials with antimicrobial activity. From synthesis to applications, RSC Polymer Chemistry Series $\mathrm{n}^{\circ}$ 10. RSC Publishing, The Royal Society of Chemistry, Cambridge, pp 22-53. https://doi. org/10.1039/9781782624998-00022

Muzzarelli RAA (1977) Chitin. Pergamon Press Ltd, Oxford

Muzzarelli RAA (1983) Chitin and its derivatives: new trends of applied research. Carbohydr Polym 3:53-75

Muzzarelli RAA (2009) Chitins and chitosans for the repair of wound skin, nerve, cartilage and bone. Carbohydr Polym 76:167-182. https://doi.org/10.1016/j.carbpol.2008.11.002

Muzzarelli RAA (2011) Chapter 17: Chitosan scaffolds for bone regeneration. In: Kim SK (ed) Chitin, chitosan, oligosaccharides and their derivatives: biological activities and applications. CRC Press/Taylor \& Francis Group LLC, Boca Raton, pp 223-240. eBook ISBN: 9781439816042

Muzzarelli RAA, de Vincenzi M (1997) Chapter 7: Chitosan as dietary food additives. In: Goosen MFA (ed) Applications of chitin and chitosan. CRC Press LLC, Boca Raton, pp 115-128 
Muzzarelli RAA, Muzzarelli C (2005) Chitosan chemistry: relevance to the biomedical sciences. Adv Polym Sci 186:151-209. https://doi.org/10.1007/b136820

Muzzarelli RAA, Muzzarelli C (2009) Chapter 31: Chitin and chitosan hydrogels. In: Handbook of hydrocolloids. Woodhead Publishing Series in Food Science, Technology and Nutrition, 2nd edn, pp 849-888. https://doi.org/10.1533/9781845695873.849

Muzzarelli R, Jeuniaux C, Gooday GW (eds) (1986a) Chitin in nature and technology. Plenum Publishing Corporation, New York

Muzzarelli RAA, Cosani A, Fornasa A, Kienzle-Sterzer CA, Rha CK, Rodriguez-Sanchez D, Scandola M, Terbojevich M, Vincendon M (1986b) Chitin and chitosan solutions. In: Muzzarelli R, Jeuniaux C, Gooday GW (eds) Chitin in nature and technology. Plenum Press, New York, pp 337-351. https://doi.org/10.1007/978-1-4613-2167-5_41

Muzzarelli RAA, Agrawal OP, Casu B, Colombo M, Compagnoni T, Domard A, Domsy JC, Ebina A, Focher B, Fuji-i K, Gadelle A, Gervasini A, Hirano S, Kondo Y, Konrad Y, Lang G, Maekita Y, Massoli A, Morazzoni F, Naggi A, Nishi A, Nishimura S, Pivari E, Rinaudo M, Roberts GAF, Scheller K, Tokura S, Torri G, Tsutsumi A, Wendel H, Wood FA (1986c) Chemically modified chitosans. In: Muzzarelli R, Jeuniaux C, Gooday GW (eds) Chitin in nature and technology. Plenum Press, New York, pp 295-320. https://doi.org/10.1007/978-1-4613-2167-5_38

Muzzarelli RAA, Boudrant J, Meyer D, Manno N, DeMarchi M, Paoletti MG (2012) Current views on fungal chitin/chitosan, human chitinases, food preservation, glucans, pectins and inulin: a tribute to Henri Braconnot, precursor of the carbohydrate polymers science, on the chitin bicentennial. Carbohydr Polym 87:995-1012. https://doi.org/10.1016/j.carbpol.2011.09.063

Nagai T, Sawayanagi Y, Nambu N (1984) Application of chitin and chitosan pharmaceutical preparations. In: Zikakis JP (ed) Chitin, chitosan, and related enzymes, part I. Academic, Orlando, pp 21-40

Naskar S, Koutsu K, Sharma S (2018) Chitosan-based nanoparticles as drug delivery systems: a review on two decades of research. J Drug Target:1-15. https://doi.org/10.1080/10611 86X.2018.1512112

Navarro-Suarez S, Flores-Palma A, Flores-Ruiz R, Gutiérrez-Pérez JL, Torres-Lagares D (2018). Nanobiomaterials in dentistry. In: Nanobiomaterials. Nanostructured materials for biomedical applications. Elsevier, pp 297-318. https://doi.org/10.1016/B978-0-08-100716-7.00011-8

Nechita P (2017) Chapter 10: Applications of chitosan in wastewater treatment. In: Shalaby EA (ed) Biological activities and application of marine polysaccharides. InTech, Rijeka, pp 209228. https://doi.org/10.5772/65289

Neville AC (1975) Biology of the arthropod cuticle. Springer, Berlin, p 448

Neville AC, Luke BM (1969a) Molecular architecture of adult locust cuticle at the electron microscope level. Tissue Cell 1:355-363

Neville AC, Luke BM (1969b) A two-system model for chitin-protein complexes in insect cuticles. Tissue Cell 1:689-707

Neville AC, Parry DAD, Woodhead-Galloway J (1976) The chitin crystallite in arthropod cuticle. J Cell Sci 21:73-82

Nezakati T, Seifalian A, Tan A, Seifalian AM (2018) Conductive polymers: opportunities and challenges in biomedical applications. Chem Rev 118:6766-6843. https://doi.org/10.1021/acs. chemrev.6b00275

Niu J, Lin HZ, Jiang SG, Chen X, Wu KC, Liu YJ, Wang S, Tian LX (2013) Comparison of effect of chitin, chitosan, chitosan oligosaccharide and N-acetyl-D-glucosamine on growth performance, antioxidant defenses and oxidative stress status of Penaeus monodon. Aquaculture 372375:1-8. https://doi.org/10.1016/j.aquaculture.2012.10.021

No HK, Meyers SP (1995) Preparation and characterization of chitin and chitosan - a review. J Aquatic Food Product Technol 4:27-52. https://doi.org/10.1300/J030v04n02_03

No HK, Meyers SP (2000) Application of chitosan for treatment of wastewaters. Rev Environ Contamination Toxicol 63:1-28. https://doi.org/10.1007/978-1-4757-6429-1_1

No HK, Meyers SP, Prinyawiwatkul W, Xu Z (2007) Applications of chitosan for improvement of quality and shelf life of foods: a review. J Food Sci 72:R87-R99. https://doi. org/10.1111/j.1750-3841.2007.00383.x 
Nwe N, Furuike T, Tamura H (2011a) Chapter 1: Chitin and chitosan from terrestrial organisms. In: Kim SK (ed) Chitin, chitosan, oligosaccharides and their derivatives: biological activities and applications. CRC Press/Taylor \& Francis Group LLC, Boca Raton, pp 3-10. eBook ISBN: 9781439816042

Nwe N, Furuike T, Tamura H (2011b) Chapter 2: Chitosan from aquatic and terrestrial organisms and microorganisms. Production, properties and applications. In: Johnson BM, Berkel ZE (eds) Biodegradable materials, Nova Science Publishers Inc., New York, pp 29-50

Nwe N, Furuike T, Tamura H (2013) Isolation and characterization of chitin and chitosan. In: Kim SK (ed) Marine biomaterials. Characterization, isolation and applications, part I, chapter 4. CRC Press/Taylor \& Francis Group LLC, Boca Raton, pp 45-60. ISBN 9781138076389

Nwe N, Furuike T, Tamura H (2014) Chapter 1: Isolation and characterization of chitin and chitosan from marine origin. Advances in food and nutrition research, vol 72, pp 1-15. https://doi. org/10.1016/B978-0-12-800269-8.00001-4

Odier A (1823) Mémoire sur la composition chimique des parties cornées des insectes. Mémoire de la Société d'Histoire Naturelle 1:29-42

Onsoyen E, Skaugrud O (1990) Metal recovery using chitosan. J Chem Technol Biotechnol 49:395-404

Oryan A, Kamali A, Moshiri A, Baharvand H, Daemi H (2018) Chemical crosslinking of biopolymeric scaffolds: current knowledge and future directions of crosslinked engineered bone scaffolds. Int J Biol Macromol 107:678-688. https://doi.org/10.1016/j.ijbiomac.2017.08.184

Orzali L, Corsi B, Forni C, Riccioni L (2017) Chapter 2: Chitosan in agriculture: a new challenge for managing plant disease. In: Shalaby EA (ed) Biological activities and application of marine polysaccharides. InTech, Rijeka, pp 17-36. DOI: https://doi.org/10.5772/66840

Osman Z, Arof AK (2017) Chapter 14: Chitosan and phthaloylated chitosan in electrochemical devices. In: Shalaby EA (ed): Biological activities and application of marine polysaccharides. InTech, Rijeka, pp 17-36. https://doi.org/10.5772/65656

Pakdel PR, Peighambardoust SJ (2018) Review on recent progress in chitosan-based hydrogels for wastewater treatment application. Carbohydr Polym 201:264-279. https://doi.org/10.1016/j. carbpol.2018.08.070

Pardeshi CV, Belgamwar VS (2016) Controlled synthesis of N,N,N-trimethyl chitosan for modulated bioadhesion and nasal membrane permeability. Int J Biol Macromol 82:933-944. https:// doi.org/10.1016/j.ijbiomac.2015.11.012

Parhi R (2017) Cross-linked hydrogel for pharmaceutical applications: a review. Adv Pharm Bull 7:515-530. https://doi.org/10.15171/apb.2017.064

Payen A (1843) Propriétés distinctives entre les membranes végétales et les enveloppes des insectes et des crustacés. Comptes Rendus des Séances de l'Académie des Sciences 17:227-231

Pellá MCG, Lima-Tenorio MK, Tenorio-Neto ET, Guilherme MR, Muniz EC, Rubira AF (2018) Chitosan-based hydrogels: from preparation to biomedical applications. Carbohydr Polym 196:233-245. https://doi.org/10.1016/j.carbpol.2018.05.033

Pelletier E, Bonnet C, Lemarchand K (2009) Biofouling growth in cold estuarine waters and evaluation of some chitosan and copper anti-fouling paints. Int J Mol Sci 10:3209-3223. https://doi. org/10.3390/ijms10073209

Peniche C, Argüelles-Monal W, Peniche H, Acosta N (2003) Chitosan: an attractive biocompatible polymer for microencapsulation. Macromol Biosci 3:51-520. https://doi.org/10.1002/ mabi.20000019

Peniche C, Argüelles-Monal W, Goycoolea FM (2008) Chapter 25: Chitin and chitosan: Major sources, properties and applications. In: Belgacem MN, Gandini A (eds) Monomers, polymers and composites from renewable resources. Elsevier, Amsterdam, pp 517-542. https://doi. org/10.1016/B978-0-08-045316-3.00025-9

Percot A, Viton C, Domard A (2003) Optimization of chitin extraction from shrimp shells. Biomacromolecules 4:12-18

Perinelli DR, Fagioli L, Campana R, Lam JKW, Baffone W, Palmieri GF, Casettari L, Bonacucina G (2018) Chitosan-based nanosystems and their exploited antimicrobial activity. Eur J Pharm Sci 117:8-20. https://doi.org/10.1016/j.ejps.2018.01.046 
Peters MG (1995) Applications and environmental aspects of chitin and chitosan. J Mat Sci Pure Appl Chem A32:629-640

Philibert T, Lee BH, Fabien N (2017) Current status and new perspectives on chitin and chitosan as functional biopolymers. Appl Biochem Biotechnol 181:1314-1337. https://doi.org/10.1007/ s12010-0162286-2

Pillai CKS, Paul W, Sharma CP (2009) Chitin and chitosan polymers: chemistry, solubility and fiber formation. Prog Polym Sci 34:641-678. https://doi.org/10.1016/j.progpolymsci.2009.04.001

Pokhrel S, Yadav PN, Adhikari R (2015) Applications of chitin and chitosan in industry and medical science: a review. Nepal J Sci Technol 16:99-104

Prabaharan M, Mano JF (2005) Chitosan-based particles as controlled drug delivery systems. Drug Del 12:41-57. https://doi.org/10.1080/10717540590889781

Prabaharan M, Mano JF (2006) Chitosan derivatives bearing cyclodextrin cavities as novel adsorbent matrices. Carbohydr Polym 63:153-166. https://doi.org/10.1016/j.carbpol.2005.08.051

Prabaharan M, Tiwari A (2011) Chapter 13: Chemical modifications of chitosan intended for biomedical applications. In: Kim SK (ed) Chitin, chitosan, oligosaccharides and their derivatives: biological activities and applications. CRC Press/Taylor \& Francis Group LLC, Boca Raton, pp 173-184. eBook ISBN: 9781439816042

Prévost M, D’Amat R (1956) Braconnot. Dictionnaire de Biographies Françaises, vol 7. Letouzey et Ané, Paris, pp 132-133

Qasim SB, Zafar MS, Najeeb S, Khurshid Z, Shah AH, Husain S, IUr R (2018) Electrospinning of chitosan-based solutions for tissue engineering and regenerative medicine. Int J Mol Sci 19:2. https://doi.org/10.3390/ijms19020407

Queiroz J, Fernandes SKSC, Azevedo EP, Barbosa AA, Fook MVL (2015) Chitosan: applicability in preventive dentistry. Dent Mater 31:e58-e59. https://doi.org/10.1016/j.dental.2015.08.130

Raafat D, Sahl HG (2009) Chitosan and its antimicrobial potential - a critical literature survey. Microbiol Biotechnol 2:186-201

Rabea EI, Badawy MET, Stevens CV, Smagghe G, Steurbault W (2003) Chitosan as antimicrobial agent: applications and mod of action. Biomacromolecules 4:1457-1465

Rafique A, Zia KM, Zuber M, Tabasum S, Rehman S (2016) Chitosan functionalized poly(vinyl alcohol) for prospects biomedical and industrial applications: a review. Int J Biol Macromol 87:141-154. https://doi.org/10.1016/j.ijbiomac.2016.02.035

Rahangdale D, Kumar A (2018) Chapter 7: Derivatized chitosan: fundamentals to applications. Biopolymer grafting applications. Elsevier, pp 251-284. https://doi.org/10.1016/ B978-0-12-810462-0.00007-7

Ramos VM, Rodríguez NM, Rodríguez MS, Heras A, Agulló E (2003) Modified chitosan carrying phosphonic and alkyl groups. Carbohydr Polym 51:425-429. https://doi.org/10.1016/ S0144-8617(02)00211-4

Rauh F, Dornish M (2006) Chapter 14: Chitosan. In: Guelcher SA, Hollinger JO (eds) An introduction to biomaterials. : CRC Press/Taylor \& Francis Group, Boca Raton, pp 249-260

Ravi Kumar MNV (2000) A review of chitin and chitosan applications. React Funct Polym 46:127. https://doi.org/10.1016/S1381-5148(00)00038-9

Ravi Kumar MNV, Muzzarelli RAA, Muzzarelli C, Sashiwa H, Domb AJ (2004) Chitosan chemistry and pharmaceutical perspectives. Chem Rev 104:6017-6087. https://doi.org/10.1021/ cr030441b

Ravichandran YD, Rajesh R (2013) Marine Polysaccharide (chitosan) and its derivatives as water purifier. Isolation and characterization of chitin and chitosan. In: Kim SK (ed) Marine biomaterials. Characterization, isolation and applications, part IV, chapter 38. CRC Press/Taylor \& Francis Group LLC, Boca Raton, pp 747-764. ISBN 9781138076389

Raymond L, Morin FG, Marchessault RH (1993) Degree of deacetylation of chitosan using conductometric titration and solid-state NMR. Carbohydr Res 246:331-336. https://doi. org/10.1016/0008-6215(93)84044-7

Rhazi M, Tolaimate A, Habibi Y (2012) Chapter 4: Interactions of chitosan with metals for water purification. In: Habibi Y, Lucia A (eds) Polysaccharide building blocks: a sustainable approach to the development of renewable biomaterials. Wiley, Hoboken, pp 127-142 